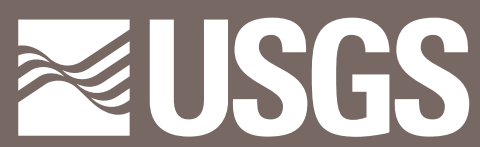

science for a changing world

Prepared in cooperation with the U.S. Army Corps of Engineers, Kansas City District

Characteristics of Sediment Data and Annual SuspendedSediment Loads and Yields for Selected Lower Missouri River Mainstem and Tributary Stations, 1976-2008

Data Series 530

U.S. Department of the Interior U.S. Geological Survey 
Front Cover. Missouri River near Kansas City. Photograph by Dale Blevins, U.S. Geological Survey, July 2006.

Back Cover. Missouri River near Rocheport, Missouri. Photograph by Dale Blevins, U.S. Geological Survey, September 2000. 


\section{Characteristics of Sediment Data and Annual Suspended-Sediment Loads and Yields for Selected Lower Missouri River Mainstem and Tributary Stations, 1976-2008}

By David C. Heimann, Patrick P. Rasmussen, Teri L. Cline, Lori M. Pigue, and Holly R. Wagner

Prepared in cooperation with the U.S. Army Corps of Engineers, Kansas City District

Data Series 530 


\section{U.S. Department of the Interior \\ KEN SALAZAR, Secretary \\ U.S. Geological Survey \\ Marcia K. McNutt, Director}

\section{U.S. Geological Survey, Reston, Virginia: 2010}

For product and ordering information:

World Wide Web: http://www.usgs.gov/pubprod

Telephone: 1-888-ASK-USGS

For more information on the USGS — the Federal source for science about the Earth,

its natural and living resources, natural hazards, and the environment:

World Wide Web: http://www.usgs.gov

Telephone: 1-888-ASK-USGS

Any use of trade, product, or firm names is for descriptive purposes only and does not imply endorsement by the U.S. Government.

Although this report is in the public domain, permission must be secured from the individual copyright owners to reproduce any copyrighted material contained within this report.

Suggested citation:

Heimann, D.C., Rasmussen, P.P., Cline, T.L., Pigue, L.M., and Wagner, H.R., 2010, Characteristics of sediment data and annual suspended-sediment loads and yields for selected lower Missouri River mainstem and tributary stations, 1976-2008: U.S. Geological Survey Data Series Report 530, 58 p. 


\section{Contents}

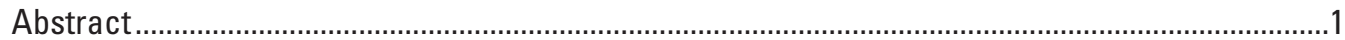

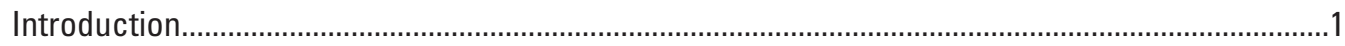

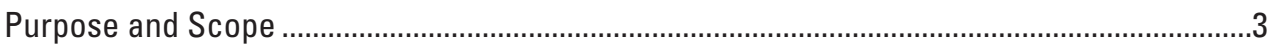

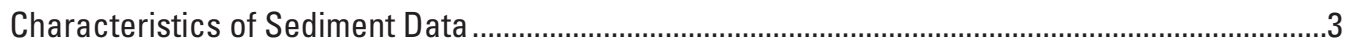

Suspended-Sediment Loads .....................................................................................

Suspended-Sediment Concentration and Particle Size .............................................................

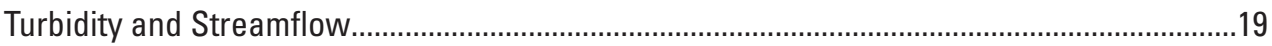

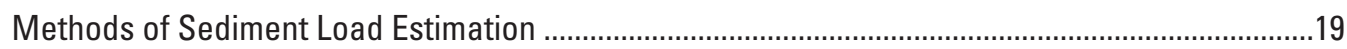

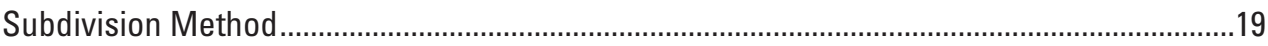

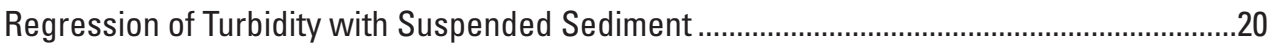

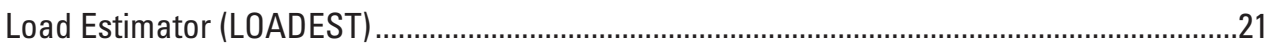

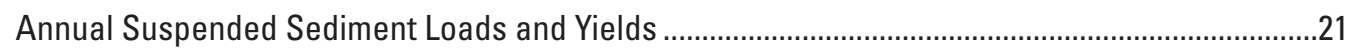

Summary

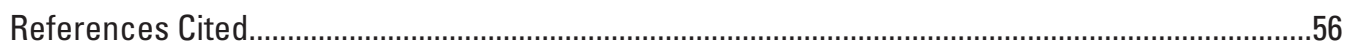

\section{Figures}

1. Map showing location of selected suspended-sediment stations within the lower Missouri River Basin

2. Graph showing relation between turbidity and suspended-sediment concentration pairs at the Missouri River at Hermann (station 06934500),

Missouri, 2006-08

\section{Tables}

1. Summary characteristics of selected suspended-sediment sampling stations in the lower Missouri River Basin

2. Summary characteristics of annual suspended-sediment and streamflow data for selected stations in the lower Missouri River Basin, 1976-2008.

3. Annual suspended-sediment and suspended-sand loads, and annual LOADEST model characteristics, for selected sediment stations in the lower Missouri River Basin, 1976-2008.

4. Annual suspended-sediment and suspended-sand yields for selected sediment stations in the lower Missouri River Basin, 1976-2008.

\section{Appendix}

1. Daily mean streamflow and suspended-sediment and suspended-sand concentration data used in LOADEST determinations of annual loads for selected Missouri River mainstem and tributary stations, 1976-2008. 


\section{Conversion Factors}

\begin{tabular}{|c|c|c|}
\hline Multiply & By & To obtain \\
\hline \multicolumn{3}{|c|}{ Length } \\
\hline inch (in.) & 25.4 & millimeter $(\mathrm{mm})$ \\
\hline foot $(\mathrm{ft})$ & 0.3048 & meter $(\mathrm{m})$ \\
\hline mile (mi) & 1.609 & kilometer (km) \\
\hline \multicolumn{3}{|c|}{ Area } \\
\hline square mile $\left(\mathrm{mi}^{2}\right)$ & 2.590 & square kilometer $\left(\mathrm{km}^{2}\right)$ \\
\hline \multicolumn{3}{|c|}{ Volume } \\
\hline cubic foot $\left(\mathrm{ft}^{3}\right)$ & 0.02832 & cubic meter $\left(\mathrm{m}^{3}\right)$ \\
\hline gallon (gal) & 3.785 & liter (L) \\
\hline \multicolumn{3}{|c|}{ Flow rate } \\
\hline cubic foot per second $\left(\mathrm{ft}^{3} / \mathrm{s}\right)$ & 0.02832 & cubic meter per second $\left(\mathrm{m}^{3} / \mathrm{s}\right)$ \\
\hline \multicolumn{3}{|c|}{ Mass } \\
\hline tons & 907.18 & Kilograms (Kg) \\
\hline ton per square mile (ton $/ \mathrm{mi}^{2}$ ) & 0.35026 & $\begin{array}{l}\text { metric ton per square kilometer } \\
\left(\text { tonne } / \mathrm{km}^{2}\right)\end{array}$ \\
\hline ton per year (ton/yr) & 0.9072 & $\begin{array}{l}\text { metric ton per year } \\
\text { (tonne per year) }\end{array}$ \\
\hline ounce, arvoirdupois (oz) & 28.35 & $\operatorname{gram}(\mathrm{g})$ \\
\hline
\end{tabular}




\title{
Characteristics of Sediment Data and Annual Suspended- Sediment Loads and Yields for Selected Lower Missouri River Mainstem and Tributary Stations, 1976-2008
}

\author{
By David C. Heimann, Patrick P. Rasmussen, Teri L. Cline, Lori M. Pigue, and Holly R. Wagner
}

\begin{abstract}
Suspended-sediment data from 18 selected surfacewater monitoring stations in the lower Missouri River Basin downstream from Gavins Point Dam were used in the computation of annual suspended-sediment and suspended-sand loads for 1976 through 2008. Three methods of suspended-sediment load determination were utilized and these included the subdivision method, regression of instantaneous turbidity with suspendedsediment concentrations at selected stations, and regression techniques using the Load Estimator (LOADEST) software. Characteristics of the suspended-sediment and streamflow data collected at the 18 monitoring stations and the tabulated annual suspended-sediment and suspended-sand loads and yields are presented.
\end{abstract}

\section{Introduction}

Before impoundment and bank-stabilization projects, the Missouri River had the largest sediment loads of any large river in the United States and contributed more than 75 percent of the sediment delivered to the Gulf of Mexico by the Mississippi River (Meade, 1995). This continual supply of sediment kept the vast wetlands near the mouth of the Mississippi above sea level and protected inland areas against damage from hurricanes. The Missouri River carried over 320 million tons of suspended-sediment per year (U.S. Army Corps of Engineers, 1980) before the dam construction period of 1953-67. Since the construction of a stabilized navigation channel and the closure of several large reservoirs on the Missouri River in the early 1950s, suspended-sediment concentrations (SSCs) have decreased at least 75 percent (Blevins, 2006) in the lower Missouri River (that portion of the river downstream from Gavins Point Dam; fig. 1). The Missouri River still accounts for nearly one-half the sediment delivered to the Gulf of Mexico (Meade, 1995).
The post-reservoir sediment decrease has had numerous effects on aquatic ecosystems, channel-bed elevations, and sediment delivery to receiving water bodies. Decreased SSCs have resulted in decreased turbidities of 60 to 80 percent in the lower Missouri River (Blevins, 2006), which may be responsible for, or contribute to, the decline of the endangered pallid sturgeon (U.S. Fish and Wildlife Service, 2003) and other native species. Channel degradation of 10 to 15 feet in reaches just below Gavins Point Dam and near Kansas City, Missouri (Jacobson and Galat, 2006; fig. 1) may be the result of post-reservoir sediment deficits in the lower Missouri River Basin. A complicating factor in the sediment dynamics of the lower Missouri River is commercial dredging for sand and fine gravel. It is unclear to what extent removed dredging materials may affect the occurrence of bed degradation but there appears to be a correlation between the two processes (Jacobson and others, 2009).

Sediment augmentations and other management activities have been proposed in response to these sediment-related issues in the lower Missouri River; however, evaluation of these activities needs to be put in the context of both historical and modern sediment loads. To do so, sediment budgets can be used to assess the impacts of proposed sedimentmanagement activities on sediment transport within the Missouri River and sediment delivery to the Mississippi River, and can account for changing sediment contributions from tributaries.

The U.S. Geological Survey (USGS) collects and analyzes suspended-sediment data in the Missouri River Basin as part of the Sediment Data Program with the U.S. Army Corps of Engineers (USACE). Additional SSC data have been collected as part of the USGS National Stream Quality Accounting Network (NASQAN; Hooper and others, 1997), and other USGS cooperative-study programs with State and local agencies. To address the need for additional sediment information on the lower Missouri River, the USGS, in cooperation with the USACE, conducted a study to determine suspended-sediment characteristics and suspendedsediment loads at selected streamgaging stations. All available 


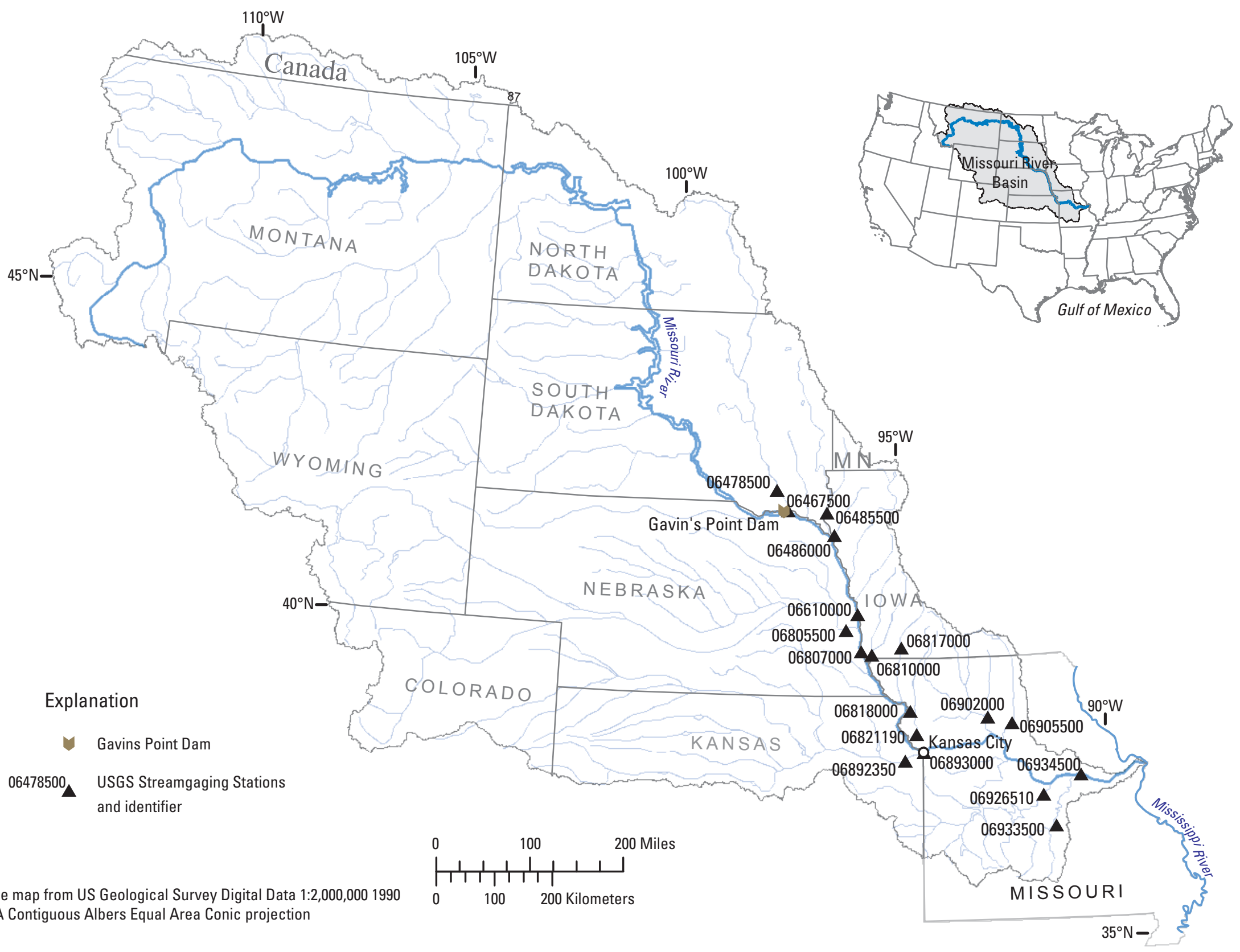

Figure 1. Location of selected sediment-sampling stations in the lower Missouri River Basin for which data are presented (see table 1 for station names corresponding to station identifiers). 
suspended-sediment data were compiled and combined for use in the computation of annual suspended-sediment and suspended-sand loads for selected Missouri River mainstem and tributary stations in the lower Missouri River Basin (fig. 1).

\section{Purpose and Scope}

This report describes characteristics of sediment data, load estimation techniques, and annual suspended-sediment loads and yields for 18 stations within the lower Missouri River Basin (fig. 1). At each station, annual suspendedsediment and suspended-sand loads are presented using available data for water years 1976 through 2008 (defined as the 12-month period from October 1 through September 30 and is designated by the year the period ends). The data analyzed for suspended-sediment loads are stored in the USGS National Water Information System (NWIS) database. The data characteristics examined include computed suspendedsediment loads, SSC, sediment particle size, turbidity, and streamflow.

\section{Characteristics of Sediment Data}

The USGS NWIS database provides for the acquisition, processing, and long-term storage of streamflow and waterquality data that are collected and analyzed by the USGS. The suspended-sediment data contained in the NWIS database were collected for numerous projects and were analyzed at several USGS or USACE laboratories. Long-term sediment data in the NWIS database include data collected as part of the USGS cooperative data program and the USGS NASQAN program. Data used in the determination of suspendedsediment loads included existing published and unpublished sediment loads, suspended-sediment concentration, sediment particle size, turbidity, and streamflow. The period of sediment and streamflow record varied at each of the 18 USGS streamgaging stations used in the analyses (table 1).

\section{Suspended-Sediment Loads}

Published and unpublished computed suspendedsediment and suspended-sand loads were available for some stations and some years in the selected 1976 through 2008 report period. Suspended-sediment and suspended-sand loads were computed for those stations and years within the 1976 through 2008 period for which loads had not been previously determined, and sufficient data were available. The data used for determination of annual suspended-sediment and suspended-sand loads were retrieved from the USGS NWIS database (U.S. Geological Survey, 2009) and USGS data archives (U.S. Geological Survey, unpub. data, 1976-2008).
Daily suspended-sediment loads computed by the USGS were available in NWIS for Missouri River stations at Sioux City, Iowa (station 06486000); Omaha (station 06610000), and Nebraska City (station 06807000), Nebraska and the Nodaway River at Clarinda, Iowa (station 06817000) (U.S. Geological Survey, 2009). Unpublished daily suspended-sediment and suspended-sand loads also were available for 1975-81 at the Missouri River stations at Saint Joseph (station 06818000), Kansas City (station 06893000), and Hermann (station 06934500), Missouri (U.S. Army Corps of Engineers, unpub. data, 1975-81). The daily computed suspended-sediment and suspended-sand loads were compiled and reported as annual values in this report.

\section{Suspended-Sediment Concentration and Particle Size}

Depth-integrated samples [continuous samples obtained from the entire vertical water column and from multiple sample locations (verticals) along a river transect] and point samples (samples obtained from selected depths or points in the water column at multiple verticals) were used in the collection of SSC and particle-size data. All suspendedsediment samples were obtained isokinetically (stream water entering the sampler nozzle did not differ in velocity from that of the water column). The spacing of the sampled verticals generally was based on equal-discharge increment (EDI) divisions or equal-width increments (EWI; Edwards and Glysson, 1999), although samples also were designated as "multiple vertical" when samples were collected using multiple verticals but did not meet the criteria for EDI or EWI sampling (table 2). Concurrent depth-integrated and point-sample data were available at some Missouri River mainstem stations and these samples were collected at the same verticals. The number of sampled verticals varied by station but generally was three to five. Suspended-sediment samples collected at Missouri River mainstem stations, for the period of record presented in this report, generally were collected with a US P-61 sampler (used to sample depthintegrated or point samples), US D-95, or the US D-96 depthintegrated sampler (table 2). Suspended-sediment sampling at smaller Missouri River tributary stations was conducted using a variety of suspended and hand-held samplers (table 2). A description of the types of isokinetic depth-integrating samplers are provided in Szalona (1982), Ward and Harr (1990), Edwards and Glysson (1999), and Federal Interagency Sedimentation Project at http://fisp.wes.army.mil/Catalog Index.htm (accessed May 27, 2010).

When available, the stored composite SSCs and sand-(suspended material greater than 0.0625 millimeters) percentage values were used in determining load estimates; otherwise the arithmetic average of sediment data from multiple-verticals was computed and used in load determinations. The multiple depth-integrated or point 
Table 1. Summary characteristics of selected suspended-sediment sampling stations in the lower Missouri River Basin.

[ $\mathrm{ft}^{3} / \mathrm{s}$, cubic feet per second; $\mathrm{mi}^{2}$, square miles]

Period of

\begin{tabular}{|c|c|c|c|c|c|c|c|}
\hline Station name & Station identifier & $\begin{array}{c}\text { Period of } \\
\text { suspended- } \\
\text { sediment record }^{\text {a }}\end{array}$ & $\begin{array}{c}\text { Period of } \\
\text { streamflow record }\end{array}$ & $\begin{array}{l}\text { Period of record } \\
\text { used in sediment- } \\
\text { load analyses }\end{array}$ & $\begin{array}{c}\text { Long-term mean } \\
\text { annual streamflow } \\
\left(\mathrm{ft}^{3} / \mathbf{s}\right)^{\mathrm{c}}\end{array}$ & $\begin{array}{c}\text { Period of } \\
\text { record used in } \\
\text { determination of } \\
\text { long-term mean } \\
\text { annual streamflow }\end{array}$ & Drainage area $\left(\mathrm{mi}^{2}\right)$ \\
\hline $\begin{array}{l}\text { Missouri River at } \\
\text { Yankton, South } \\
\text { Dakota }\end{array}$ & 06467500 & 1939-69, 2001-09 & $1931-95,2001-10$ & $2001-08$ & 26,000 & $1976-95$ & 279,500 \\
\hline $\begin{array}{l}\text { James River at } \\
\text { Scotland, South } \\
\text { Dakota }\end{array}$ & 06478500 & 1975-95, 2007 & $1928-2010$ & $1976-95$ & 624 & 1929-2008 & 20,653 \\
\hline $\begin{array}{l}\text { Big Sioux River at } \\
\text { Akron, Iowa }\end{array}$ & 06485500 & $\begin{array}{c}1940-51,1967 \\
1970-94,2002 \\
2004-08\end{array}$ & 1929-2010 & 1976-94 & 1,280 & 1929-2008 & 8,424 \\
\hline $\begin{array}{l}\text { Missouri River at } \\
\text { Sioux City, Iowa }\end{array}$ & 06486000 & $\begin{array}{r}1955-2001 \\
2004-10\end{array}$ & 1929-2010 & $1976-2008$ & 28,800 & 1953-2008 & 314,600 \\
\hline $\begin{array}{l}\text { Missouri River at } \\
\text { Omaha, Nebraska }\end{array}$ & 06610000 & 1939-2010 & $1928-2010$ & 1976-2008 & 32,300 & $1953-2008$ & 322,800 \\
\hline $\begin{array}{c}\text { Platte River at } \\
\text { Louisville, } \\
\text { Nebraska }^{e}\end{array}$ & 06805500 & $\begin{array}{l}\text { 1939-71, } \\
1973-2010\end{array}$ & $1953-2010$ & 1976-2008 & 7,000 & $1953-2008$ & 85,370 \\
\hline $\begin{array}{l}\text { Missouri River at } \\
\text { Nebraska City, } \\
\text { Nebraska }\end{array}$ & 06807000 & $1951-2010$ & 1929-2010 & $1976-2008$ & 38,500 & $1953-2008$ & 410,000 \\
\hline $\begin{array}{l}\text { Nishnabotna River } \\
\text { at Hamburg, } \\
\text { Iowa }\end{array}$ & 06810000 & $\begin{array}{c}1939-51,1978-93 \\
1998,2004-09\end{array}$ & $1922-2010$ & $1982-93,2004-08$ & 1,290 & $1922-2008$ & 2,806 \\
\hline $\begin{array}{l}\text { Nodaway River at } \\
\text { Clarinda, Iowa }\end{array}$ & 06817000 & $\begin{array}{c}1970-74,1976-92 \\
2008\end{array}$ & $1918-2010$ & 1976-92 & 386 & 1919-2009 & 762 \\
\hline $\begin{array}{l}\text { Missouri River } \\
\text { at St. Joseph, } \\
\text { Missouri }\end{array}$ & 06818000 & $1948-2010$ & $1929-2010$ & $1976-2008$ & 45,400 & 1948-2009 & 426,500 \\
\hline $\begin{array}{l}\text { Platte River at } \\
\text { Sharps Station, } \\
\text { Missouri }\end{array}$ & 06821190 & 1979-93, 1995 & 1979-2010 & 1980-92 & 1,700 & 1979-2008 & 2,380 \\
\hline
\end{tabular}

Missouri 
Table 1. Summary characteristics of selected suspended-sediment sampling stations in the lower Missouri River Basin-Continued $\left[\mathrm{ft}^{3} / \mathrm{s}\right.$, cubic feet per second; $\mathrm{mi}^{2}$, square miles]

\begin{tabular}{|c|c|c|c|c|c|c|c|}
\hline Station name & Station identifier & $\begin{array}{c}\text { Period of } \\
\text { suspended- } \\
\text { sediment record }^{\mathrm{a}}\end{array}$ & $\begin{array}{c}\text { Period of } \\
\text { streamflow record }\end{array}$ & $\begin{array}{l}\text { Period of record } \\
\text { used in sediment- } \\
\text { load analyses }\end{array}$ & $\begin{array}{c}\text { Long-term mean } \\
\text { annual streamflow } \\
\left(\mathrm{ft}^{3} / \mathbf{s}\right)^{c}\end{array}$ & $\begin{array}{c}\text { Period of } \\
\text { record used in } \\
\text { determination of } \\
\text { long-term mean } \\
\text { annual streamflow }\end{array}$ & Drainage area $\left(\mathrm{mi}^{2}\right)$ \\
\hline $\begin{array}{l}\text { Kansas River at } \\
\text { DeSoto, Kansas }\end{array}$ & 06892350 & $\begin{array}{c}1948-92,1999- \\
2005,2007\end{array}$ & $1917-2010$ & $1976-91$ & 7,320 & 1918-2009 & 59,756 \\
\hline $\begin{array}{l}\text { Missouri River at } \\
\text { Kansas City, } \\
\text { Missouri }\end{array}$ & 06893000 & $\begin{array}{c}1948-76,1988- \\
2010\end{array}$ & 1929-2010 & 1976-2008 & 54,900 & $1958-2008$ & 484,100 \\
\hline $\begin{array}{l}\text { Grand River at } \\
\text { Sumner, Missouri }\end{array}$ & 06902000 & $\begin{array}{c}1974-86,1988-93 \\
1995\end{array}$ & $1925-2010$ & 1976-93 & 4,170 & 1925-2008 & 6,880 \\
\hline $\begin{array}{l}\text { Chariton River } \\
\text { at Prairie Hill, } \\
\text { Missouri }^{\mathbf{h}}\end{array}$ & 06905500 & $1970-74,1978-86$ & 1929-2010 & $1979-86$ & 1,260 & 1929-2008 & 1,870 \\
\hline $\begin{array}{l}\text { Osage River at } \\
\text { St. Thomas, } \\
\text { Missouri }^{i}\end{array}$ & 06926510 & $1943-51,1972-94$ & $1931-96^{\mathbf{j}}$ & 1976-94 & 11,700 & 1996-2008 & 14,584 \\
\hline $\begin{array}{l}\text { Gasconade River at } \\
\text { Jerome, Missouri }\end{array}$ & 06933500 & $1942-51,1978-93$ & 1903-2010 & 1978-93 & 2,600 & 1903-2008 & 2,840 \\
\hline $\begin{array}{l}\text { Missouri River } \\
\text { at Hermann, } \\
\text { Missouri }\end{array}$ & 06934500 & $1948-2010$ & 1929-2010 & $1976-2008$ & 86,200 & 1949-2008 & 522,500 \\
\hline
\end{tabular}

a Source: U.S. Geological Survey (2009) and Keown (1981)

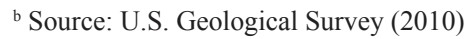

${ }^{c}$ Source: U.S. Geological Survey annual water data report accessed through U.S. Geological Survey (2009)

d Source: United States Army Corps of Engineers, written communication (2009).

${ }^{\mathrm{e}}$ Sediment information from 1939-52 is from Platte River at Ashland, Nebraska (station 06801000).

${ }_{\mathrm{f}}^{\mathrm{f}}$ Sediment information from 1970-74 is from Nodaway River at Burlington Junction, Missouri (station 06817500).

${ }^{\mathrm{g}}$ Sediment information from 1948-73 is from Kansas River at Bonner Springs, Kansas (station 06892500).

${ }^{\mathrm{h}}$ Sediment information from 1970-74 is from Chariton River near Rathbun, Iowa (station 06903900).

${ }^{i}$ Sediment information from 1943-51 is from Osage River at Osceola, Missouri (station 06920500).

${ }^{j}$ Streamflow information from Osage River below St. Thomas, Missouri (station 06926500). 
Table 2. Summary characteristics of annual suspended-sediment and streamflow data for selected stations in the lower Missouri River Basin, 1976-2008.

[EDI, equal-discharge increment; EWI, equal-width increment; DI, depth-integrated sample; PS, point sample; mg/L, milligrams per liter; fts,s, cubic feet per second; --, no data or not applicable]

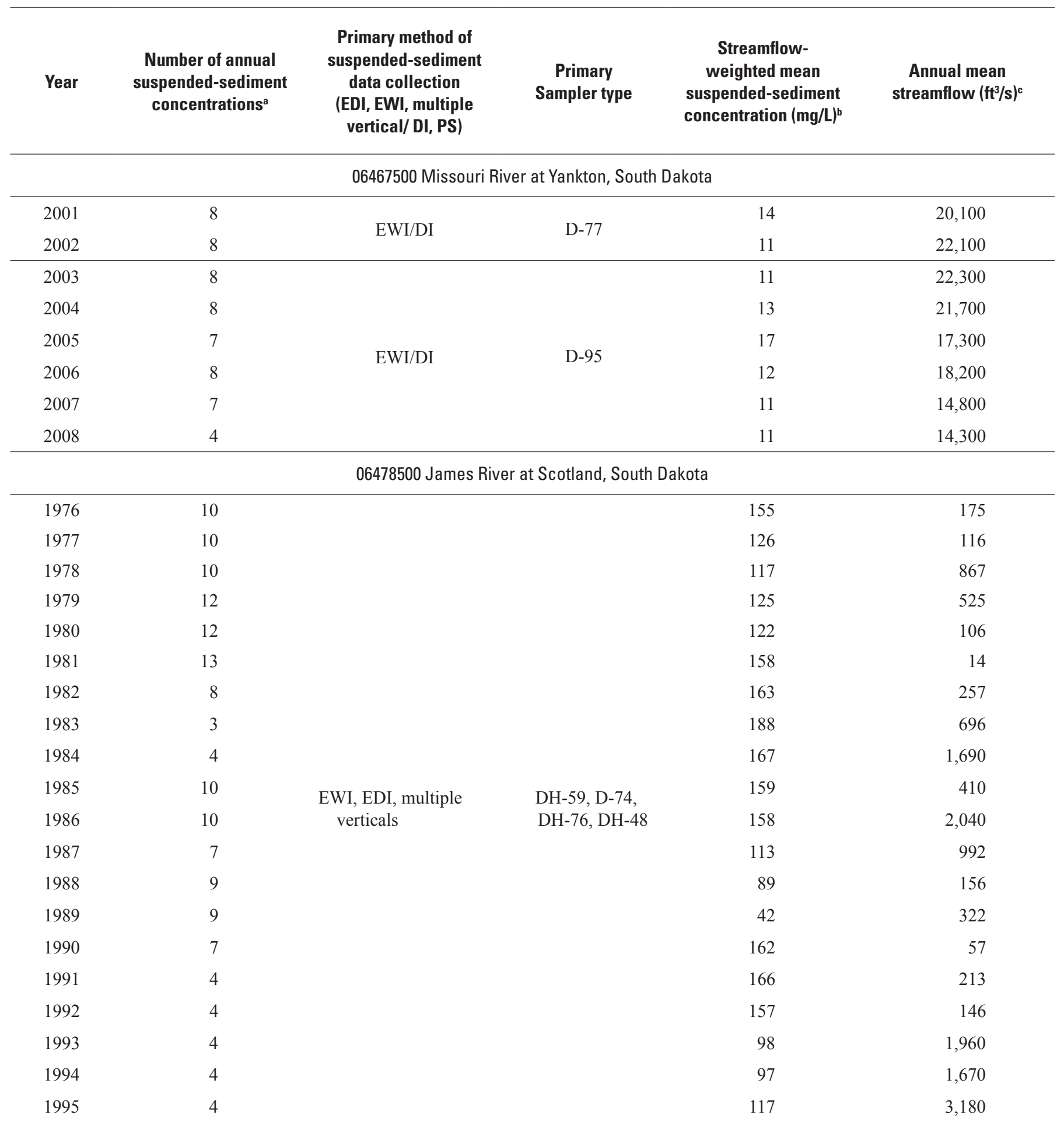


Table 2. Summary characteristics of annual suspended-sediment and streamflow data for selected stations in the lower Missouri River Basin, 1976-2008-Continued

[EDI, equal-discharge increment; EWI, equal-width increment; DI, depth-integrated sample; PS, point sample; mg/L, milligrams per liter; $\mathrm{ft}^{3} / \mathrm{s}$, cubic feet per second; --, no data or not applicable]

\begin{tabular}{|c|c|c|c|c|c|}
\hline \multicolumn{6}{|c|}{06485500 Big Sioux River at Akron, lowa } \\
\hline 1977 & 12 & \multirow{12}{*}{ EDI/DI } & \multirow{12}{*}{ DH-76, DH-48 } & 279 & 231 \\
\hline 1978 & 10 & & & 350 & 1,480 \\
\hline 1979 & 12 & & & 325 & 1,970 \\
\hline 1980 & 11 & & & 562 & 1,110 \\
\hline 1984 & 3 & & & 743 & 4,270 \\
\hline 1985 & 4 & & & 369 & 2,170 \\
\hline 1986 & 3 & & & 623 & 3,930 \\
\hline 1987 & 4 & & & 395 & 1,770 \\
\hline 1988 & 3 & & & 367 & 664 \\
\hline 1989 & 5 & & & 372 & 404 \\
\hline 1990 & 4 & & & 451 & 449 \\
\hline 1991 & 3 & & & 360 & 460 \\
\hline
\end{tabular}


Table 2. Summary characteristics of annual suspended-sediment and streamflow data for selected stations in the lower Missouri River Basin, 1976-2008-Continued

[EDI, equal-discharge increment; EWI, equal-width increment; DI, depth-integrated sample; PS, point sample; mg/L, milligrams per liter; fts $/ \mathrm{s}$, cubic feet per second; --, no data or not applicable]

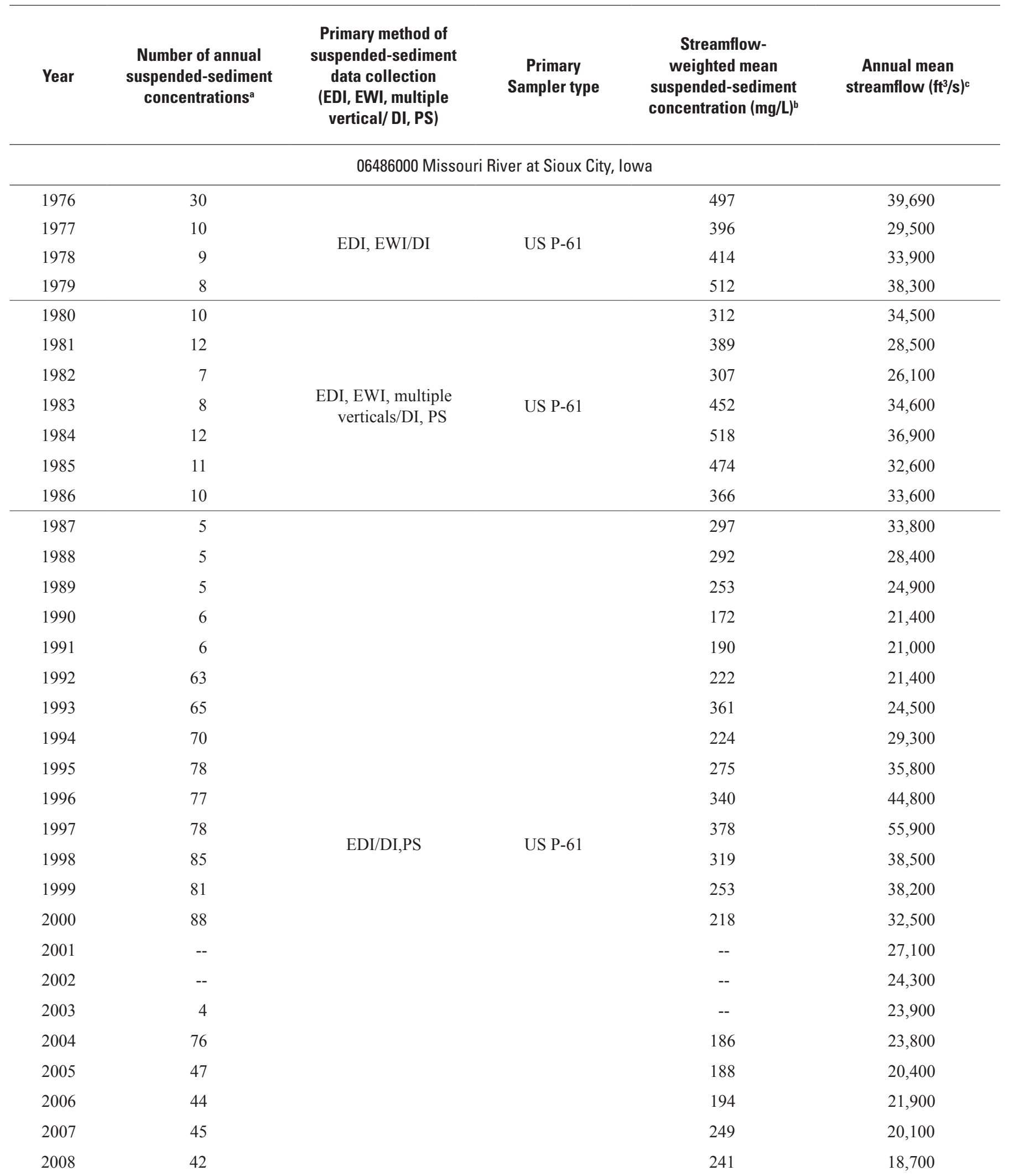


Table 2. Summary characteristics of annual suspended-sediment and streamflow data for selected stations in the lower Missouri River Basin, 1976-2008-Continued

[EDI, equal-discharge increment; EWI, equal-width increment; DI, depth-integrated sample; PS, point sample; mg/L, milligrams per liter; fts, cubic feet per second; --, no data or not applicable]

\begin{tabular}{|c|c|c|c|c|c|}
\hline \multicolumn{6}{|c|}{06610000 Missouri River at Omaha, Nebraska } \\
\hline 1977 & 5 & \multirow{11}{*}{ EDI,EWI/DI, PS } & \multirow{11}{*}{ US P-61 } & 480 & 30,500 \\
\hline 1978 & 12 & & & 690 & 36,200 \\
\hline 1979 & 13 & & & 772 & 42,500 \\
\hline 1980 & 12 & & & 603 & 34,500 \\
\hline 1984 & 11 & & & 784 & 46,100 \\
\hline 1985 & 11 & & & 641 & 38,500 \\
\hline 1986 & 10 & & & 705 & 40,500 \\
\hline 1987 & 5 & & & 564 & 40,700 \\
\hline 1988 & 5 & & & 379 & 31,600 \\
\hline 1989 & 5 & & & 310 & 27,300 \\
\hline 1990 & 6 & & & 381 & 24,600 \\
\hline 1997 & -- & \multirow{12}{*}{ EDI,EWI/DI } & \multirow{12}{*}{ US P-61 } & 531 & 62,200 \\
\hline 1998 & -- & & & 532 & 43,900 \\
\hline 1999 & 4 & & & 396 & 44,600 \\
\hline 2000 & 89 & & & 276 & 35,900 \\
\hline 2001 & 92 & & & 524 & 30,800 \\
\hline 2002 & 96 & & & 261 & 26,300 \\
\hline 2003 & 105 & & & 376 & 26,600 \\
\hline 2004 & 15 & & & 368 & 27,000 \\
\hline 2005 & 14 & & & 352 & 23,400 \\
\hline 2006 & 13 & & & 243 & 24,300 \\
\hline 2007 & 13 & & & 426 & 24,800 \\
\hline 2008 & 13 & & & 512 & 24,600 \\
\hline
\end{tabular}


Table 2. Summary characteristics of annual suspended-sediment and streamflow data for selected stations in the lower Missouri River Basin, 1976-2008-Continued

[EDI, equal-discharge increment; EWI, equal-width increment; DI, depth-integrated sample; PS, point sample; mg/L, milligrams per liter; $\mathrm{ft}^{3} / \mathrm{s}$, cubic feet per second; --, no data or not applicable]

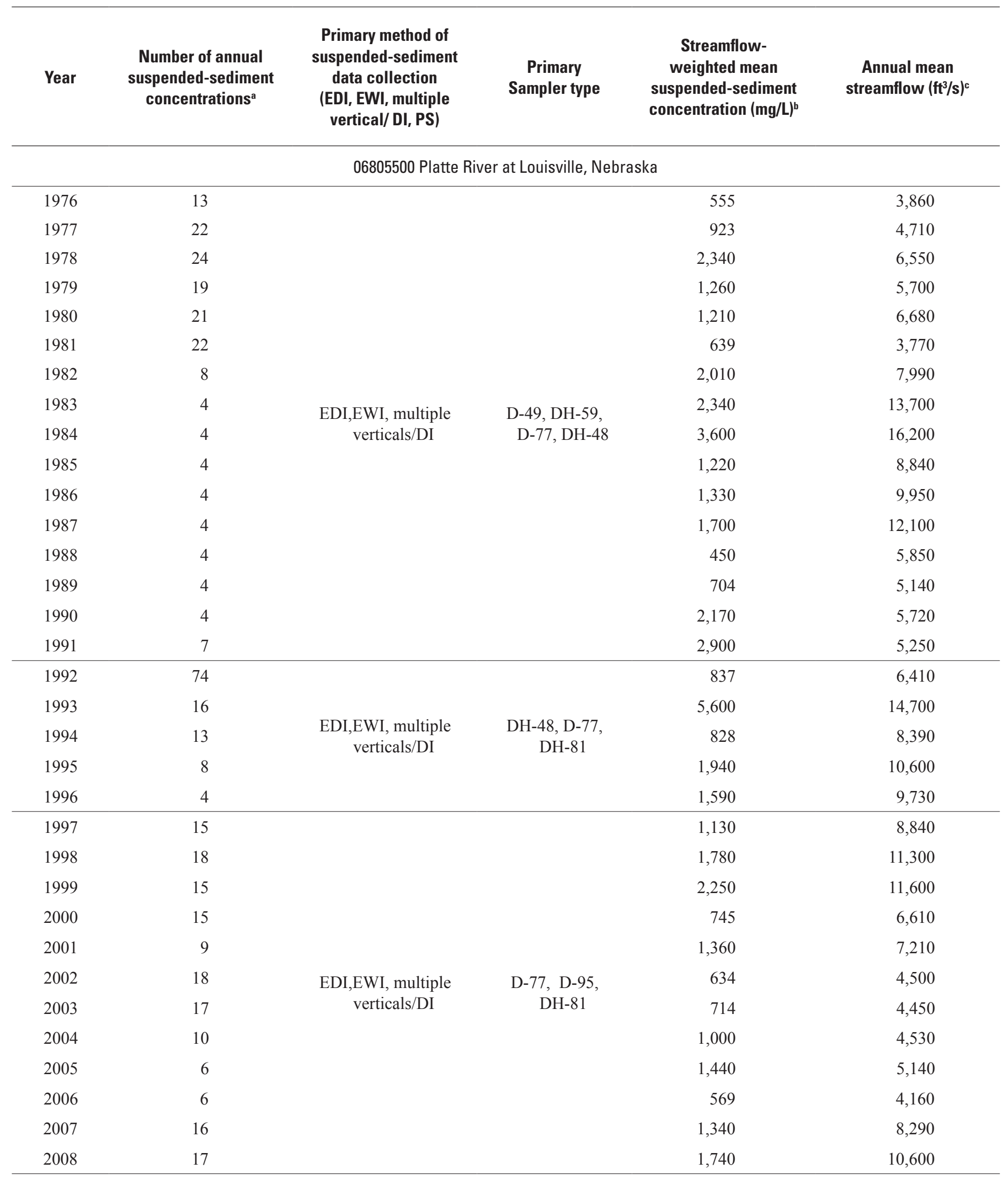


Table 2. Summary characteristics of annual suspended-sediment and streamflow data for selected stations in the lower Missouri River Basin, 1976-2008-Continued

[EDI, equal-discharge increment; EWI, equal-width increment; DI, depth-integrated sample; PS, point sample; mg/L, milligrams per liter; $\mathrm{ft}^{3} / \mathrm{s}$, cubic feet per second; --, no data or not applicable]

\begin{tabular}{|c|c|c|c|c|c|}
\hline \multicolumn{6}{|c|}{06807000 Missouri River at Nebraska City, Nebraska } \\
\hline 1977 & 12 & & & 697 & 35,000 \\
\hline 1978 & 5 & & & 779 & 43,300 \\
\hline 1979 & 5 & & & 830 & 48,000 \\
\hline 1980 & 5 & & & 495 & 40,200 \\
\hline 1984 & 5 & EDI/DI, PS & US P-61 & 1,450 & 61,700 \\
\hline 1985 & 5 & & & 973 & 45,500 \\
\hline 1986 & 6 & & & 814 & 47,900 \\
\hline 1987 & 5 & & & 998 & 51,200 \\
\hline 1988 & 5 & & & 434 & 35,600 \\
\hline 1989 & 6 & & & 404 & 30,700 \\
\hline 1990 & 3 & & & 591 & 28,000 \\
\hline 1991 & 5 & & & 680 & 28,700 \\
\hline 1997 & 78 & & & 629 & 66,500 \\
\hline 1998 & 77 & & & 755 & 52,100 \\
\hline 1999 & 80 & & & 604 & 53,000 \\
\hline 2000 & 85 & EDI/DI & US P-61 & 363 & 39,700 \\
\hline 2001 & 73 & & & 615 & 38,000 \\
\hline 2002 & 78 & & & 372 & 30,600 \\
\hline 2003 & 86 & & & 485 & 30,800 \\
\hline 2004 & 81 & & & 527 & 31,400 \\
\hline 2005 & 84 & & & 510 & 28,500 \\
\hline 2006 & 78 & & & 335 & 28,300 \\
\hline 2007 & 82 & & & 674 & 33,300 \\
\hline 2008 & 78 & & & 984 & 34,900 \\
\hline
\end{tabular}


Table 2. Summary characteristics of annual suspended-sediment and streamflow data for selected stations in the lower Missouri River Basin, 1976-2008-Continued

[EDI, equal-discharge increment; EWI, equal-width increment; DI, depth-integrated sample; PS, point sample; mg/L, milligrams per liter; $\mathrm{ft}^{3} / \mathrm{s}$, cubic feet per second; --, no data or not applicable]

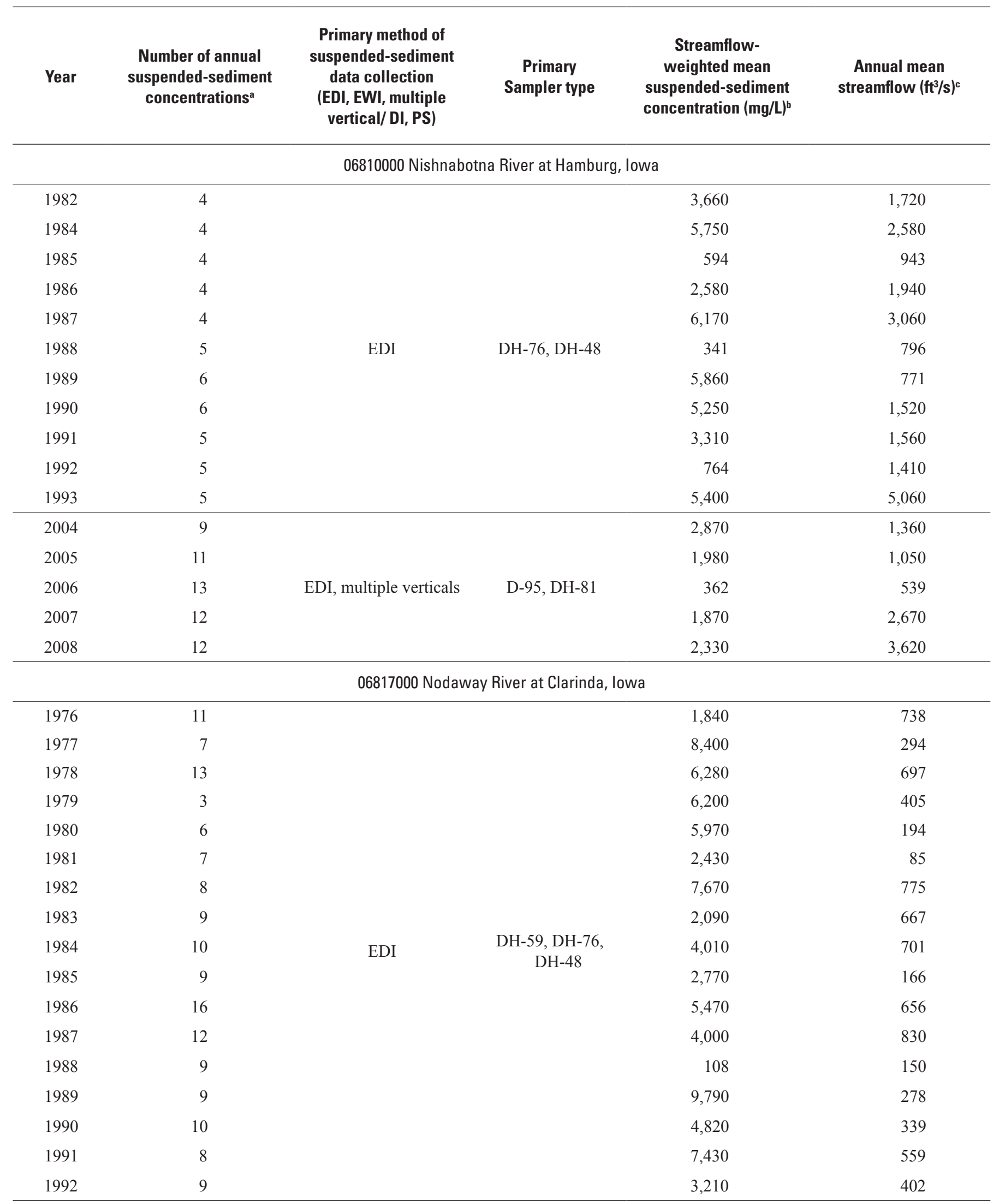


Table 2. Summary characteristics of annual suspended-sediment and streamflow data for selected stations in the lower Missouri River Basin, 1976-2008-Continued

[EDI, equal-discharge increment; EWI, equal-width increment; DI, depth-integrated sample; PS, point sample; mg/L, milligrams per liter; $\mathrm{ft}^{3} / \mathrm{s}$, cubic feet per second; --, no data or not applicable]

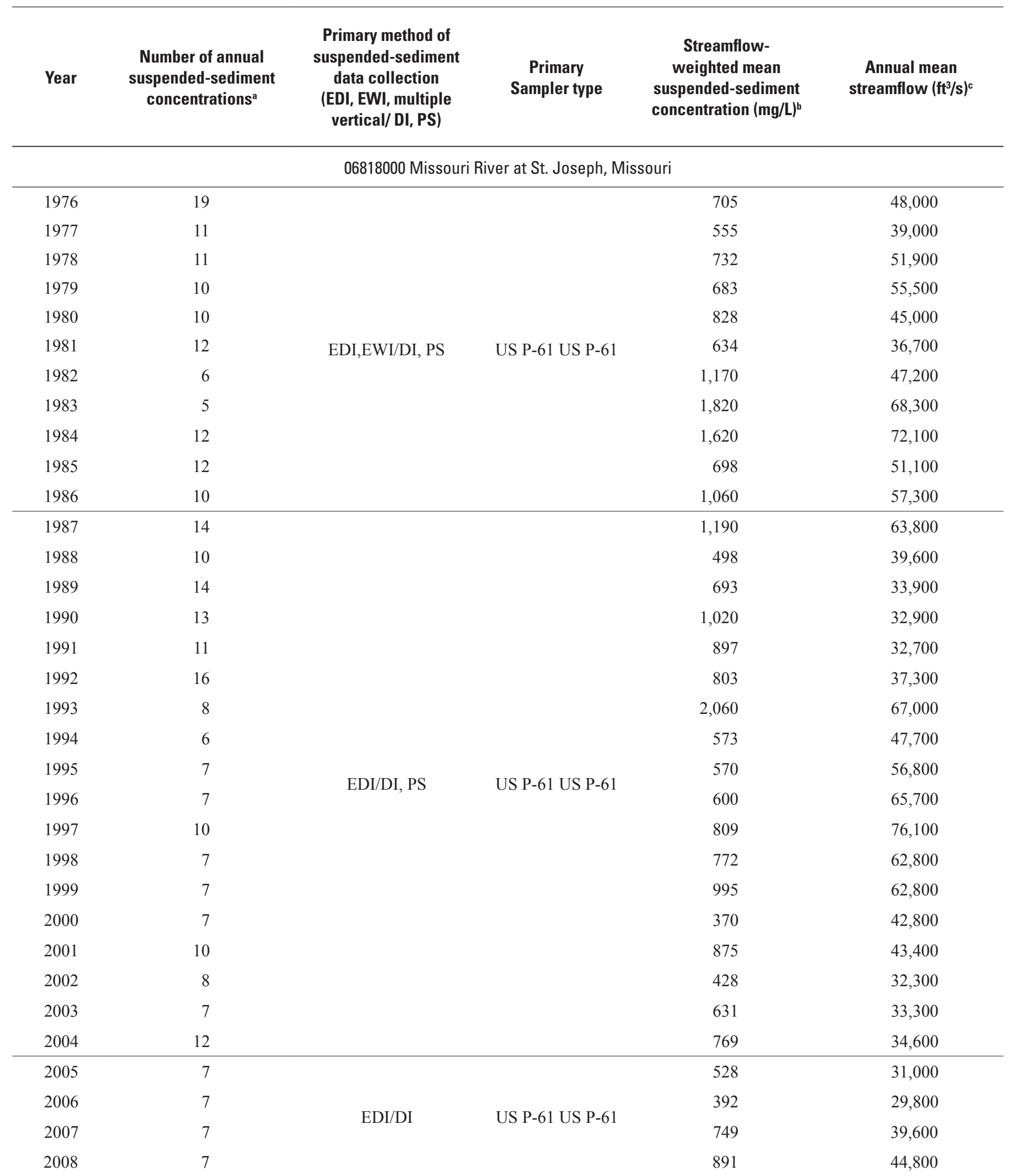


Table 2. Summary characteristics of annual suspended-sediment and streamflow data for selected stations in the lower Missouri River Basin, 1976-2008-Continued

[EDI, equal-discharge increment; EWI, equal-width increment; DI, depth-integrated sample; PS, point sample; mg/L, milligrams per liter; fts $/ \mathrm{s}$, cubic feet per second; --, no data or not applicable]

\begin{tabular}{|c|c|c|c|c|c|}
\hline Year & $\begin{array}{l}\text { Number of annual } \\
\text { suspended-sediment } \\
\text { concentrations }^{\mathrm{a}}\end{array}$ & $\begin{array}{l}\text { Primary method of } \\
\text { suspended-sediment } \\
\text { data collection } \\
\text { (EDI, EWI, multiple } \\
\text { vertical/ DI, PS) }\end{array}$ & $\begin{array}{c}\text { Primary } \\
\text { Sampler type }\end{array}$ & $\begin{array}{c}\text { Streamflow- } \\
\text { weighted mean } \\
\text { suspended-sediment } \\
\text { concentration (mg/L) }\end{array}$ & $\begin{array}{c}\text { Annual mean } \\
\text { streamflow }\left(\mathrm{ft}^{3} / \mathrm{s}\right)\end{array}$ \\
\hline \multicolumn{6}{|c|}{06821190 Platte River at Sharps Station, Missouri } \\
\hline 1980 & 10 & \multirow{12}{*}{ EWI/DI } & \multirow{12}{*}{ D-74, DH-48 } & 2,030 & 767 \\
\hline 1981 & 6 & & & 2,100 & 833 \\
\hline 1982 & 6 & & & 8,230 & 3,380 \\
\hline 1983 & 4 & & & 2,160 & 2,200 \\
\hline 1984 & 4 & & & 4,320 & 2,540 \\
\hline 1985 & 4 & & & 1,190 & 842 \\
\hline 1986 & 4 & & & 2,210 & 3,320 \\
\hline 1987 & 4 & & & 1,050 & 2,540 \\
\hline 1988 & 3 & & & 572 & 526 \\
\hline 1989 & 4 & & & 1,350 & 464 \\
\hline 1990 & 4 & & & 1,070 & 1,440 \\
\hline 1991 & 4 & & & 983 & 1,010 \\
\hline 1992 & 4 & EWI/DI & D-74, DH-81 & 1,290 & 1,730 \\
\hline \multicolumn{6}{|c|}{06892350 Kansas River at DeSoto, Kansas } \\
\hline 1976 & 23 & \multirow{6}{*}{ EDI/DI, PS } & \multirow{6}{*}{ D-74 } & 1,170 & 3,740 \\
\hline 1977 & 18 & & & 3,330 & 5,890 \\
\hline 1978 & 173 & & & 757 & 8,640 \\
\hline 1979 & 108 & & & 1,470 & 9,100 \\
\hline 1980 & 128 & & & 1,070 & 6,340 \\
\hline 1981 & 136 & & & 1,140 & 4,150 \\
\hline 1982 & 144 & \multirow{10}{*}{$\mathrm{EDI} / \mathrm{DI}$} & \multirow{10}{*}{ D-74 } & 1,840 & 12,100 \\
\hline 1983 & 6 & & & 699 & 9,040 \\
\hline 1984 & 7 & & & 1,380 & 12,700 \\
\hline 1985 & 6 & & & 547 & 7,650 \\
\hline 1986 & 7 & & & 1,020 & 11,700 \\
\hline 1987 & 6 & & & 1,390 & 16,900 \\
\hline 1988 & 14 & & & 201 & 2,910 \\
\hline 1989 & 17 & & & 1,640 & 2,700 \\
\hline 1990 & 8 & & & 1,470 & 5,530 \\
\hline 1991 & 6 & & & 594 & 2,650 \\
\hline
\end{tabular}


Table 2. Summary characteristics of annual suspended-sediment and streamflow data for selected stations in the lower Missouri River Basin, 1976-2008-Continued

[EDI, equal-discharge increment; EWI, equal-width increment; DI, depth-integrated sample; PS, point sample; mg/L, milligrams per liter; $\mathrm{ft}^{3} / \mathrm{s}$, cubic feet per second; --, no data or not applicable]

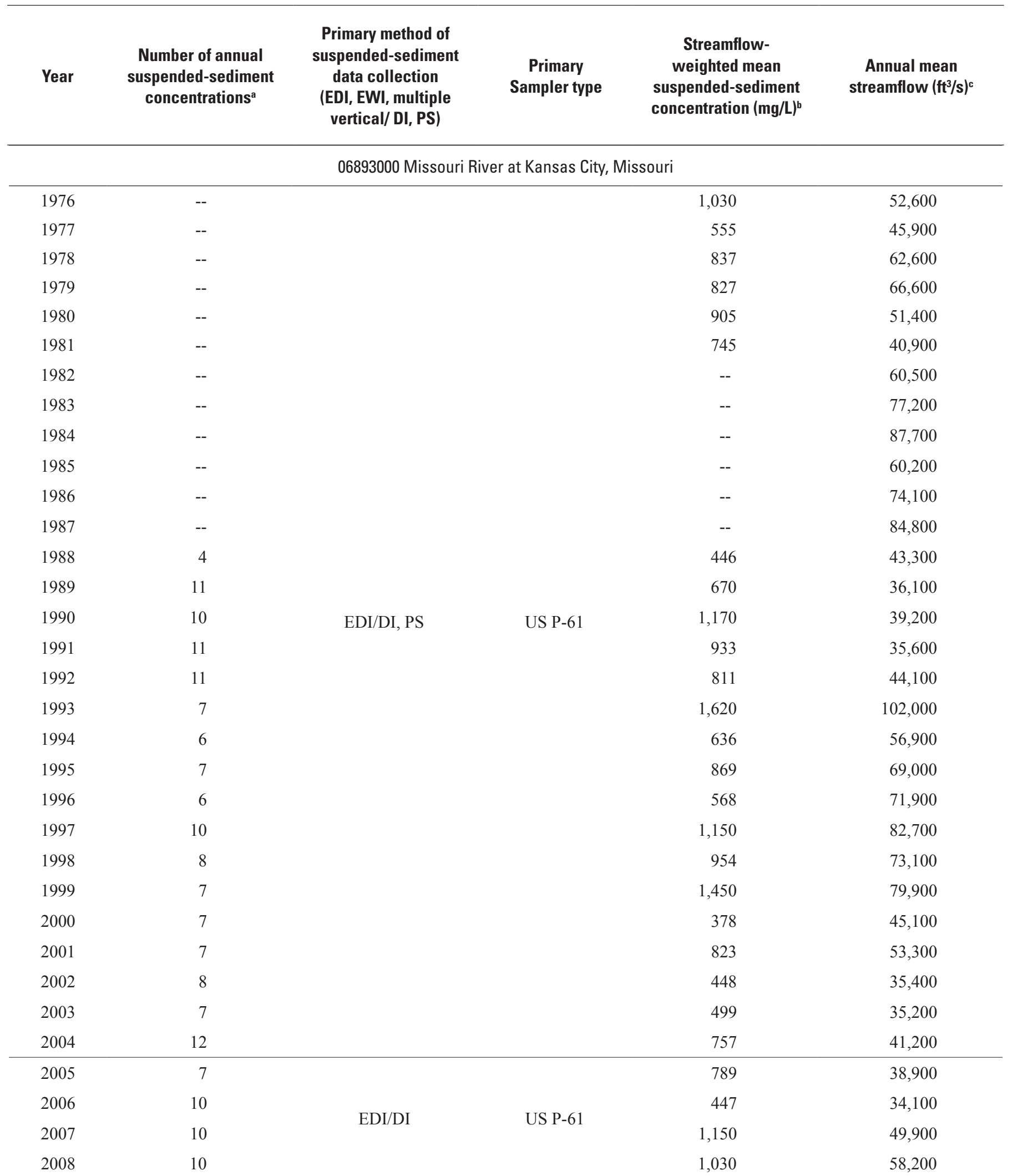


Table 2. Summary characteristics of annual suspended-sediment and streamflow data for selected stations in the lower Missouri River Basin, 1976-2008-Continued

[EDI, equal-discharge increment; EWI, equal-width increment; DI, depth-integrated sample; PS, point sample; mg/L, milligrams per liter; fts $/ \mathrm{s}$, cubic feet per second; --, no data or not applicable]

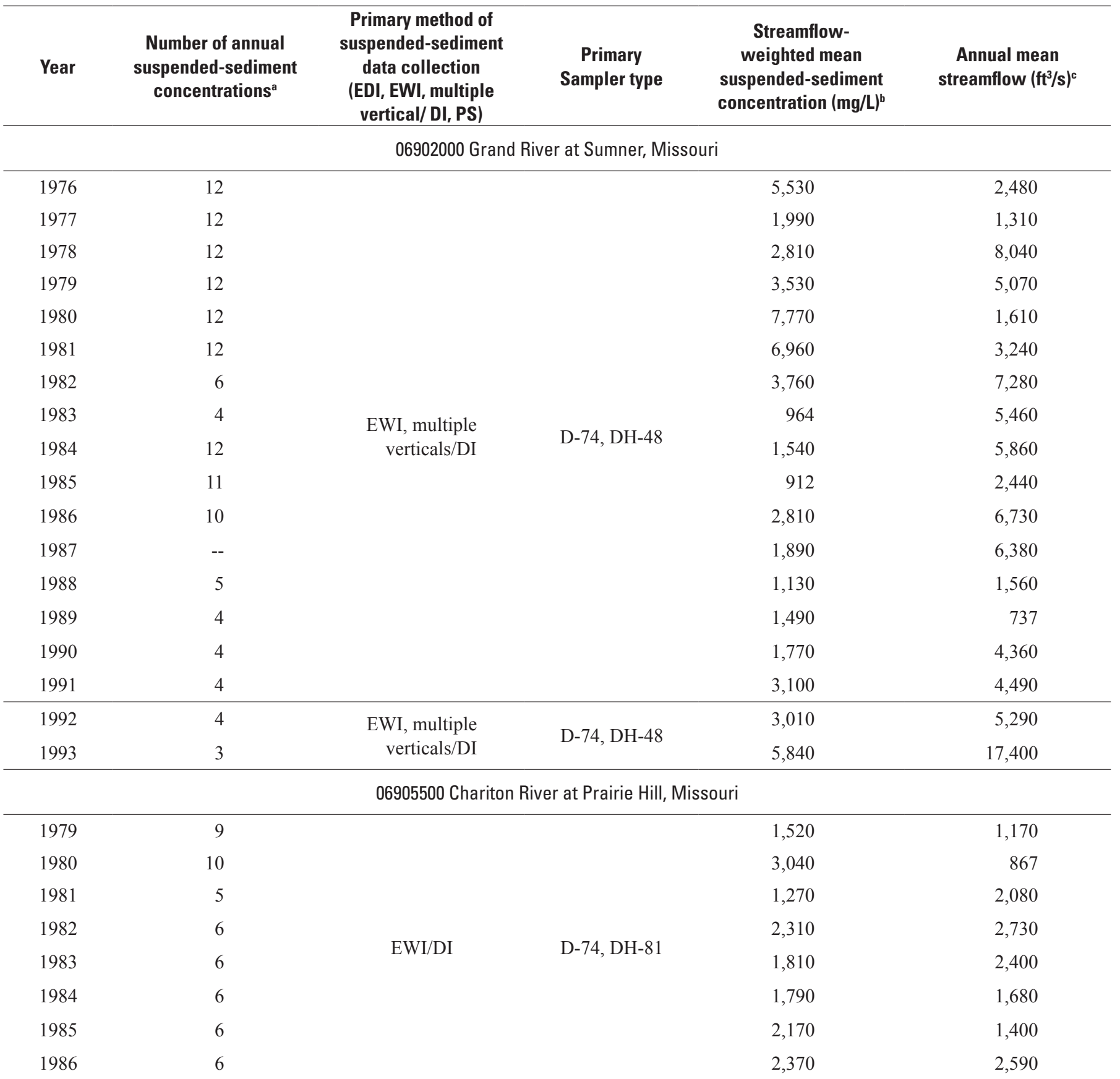


Table 2. Summary characteristics of annual suspended-sediment and streamflow data for selected stations in the lower Missouri River Basin, 1976-2008-Continued

[EDI, equal-discharge increment; EWI, equal-width increment; DI, depth-integrated sample; PS, point sample; mg/L, milligrams per liter; fts, cubic feet per second; --, no data or not applicable]

\begin{tabular}{|c|c|c|c|c|c|}
\hline Year & $\begin{array}{l}\text { Number of annual } \\
\text { suspended-sediment } \\
\text { concentrations }^{\mathrm{a}}\end{array}$ & $\begin{array}{l}\text { Primary method of } \\
\text { suspended-sediment } \\
\text { data collection } \\
\text { (EDI, EWI, multiple } \\
\text { vertical/ DI, PS) }\end{array}$ & $\begin{array}{c}\text { Primary } \\
\text { Sampler type }\end{array}$ & $\begin{array}{c}\text { Streamflow- } \\
\text { weighted mean } \\
\text { suspended-sediment } \\
\text { concentration (mg/L) }\end{array}$ & $\begin{array}{c}\text { Annual mean } \\
\text { streamflow }\left(\mathrm{ft}^{3} / \mathrm{s}\right)^{\mathrm{c}}\end{array}$ \\
\hline
\end{tabular}

06926510 Osage River at St. Thomas, Missouri

\begin{tabular}{|c|c|c|c|c|}
\hline 1976 & 12 & \multirow{11}{*}{$\begin{array}{l}\text { EWI, multiple } \\
\text { verticals/DI }\end{array}$} & 75 & 5,440 \\
\hline 1977 & 11 & & 133 & 4,900 \\
\hline 1978 & 11 & & 132 & 8,770 \\
\hline 1980 & 8 & & 261 & 4,830 \\
\hline 1981 & 11 & & 153 & 7,830 \\
\hline 1983 & 6 & & 46 & 14,800 \\
\hline 1984 & 6 & & 36 & 15,200 \\
\hline 1985 & 6 & & 32 & 20,100 \\
\hline 1986 & 6 & & 23 & 15,100 \\
\hline 1990 & 5 & & 67 & 16,300 \\
\hline 1991 & 6 & & 26 & 4,510 \\
\hline 1992 & 2 & \multirow{3}{*}{$\begin{array}{r}\text { EWI, multiple } \\
\text { verticals/DI }\end{array}$} & 32 & 6,200 \\
\hline 1993 & 4 & & 38 & 25,200 \\
\hline 1994 & 2 & & 46 & 23,200 \\
\hline \multicolumn{5}{|c|}{06933500 Gasconade River at Jerome, Missouri } \\
\hline 1978 & 8 & \multirow{10}{*}{$\begin{array}{c}\text { EDI, multiple verticals/ } \\
\text { DI }\end{array}$} & 158 & 2,260 \\
\hline 1985 & 6 & & 26 & 6,490 \\
\hline 1986 & 6 & & 18 & 2,860 \\
\hline 1987 & 11 & & 33 & 2,320 \\
\hline 1988 & 11 & & 25 & 3,180 \\
\hline 1989 & 9 & & 53 & 2,450 \\
\hline 1990 & 5 & & 75 & 3,570 \\
\hline 1991 & 6 & & 70 & 2,910 \\
\hline 1992 & 5 & & 58 & 1,900 \\
\hline 1993 & 3 & & -- & 4,330 \\
\hline
\end{tabular}


Table 2. Summary characteristics of annual suspended-sediment and streamflow data for selected stations in the lower Missouri River Basin, 1976-2008-Continued

[EDI, equal-discharge increment; EWI, equal-width increment; DI, depth-integrated sample; PS, point sample; mg/L, milligrams per liter; fts, cubic feet per second; --, no data or not applicable]

\begin{tabular}{|c|c|c|c|c|c|}
\hline Year & $\begin{array}{l}\text { Number of annual } \\
\text { suspended-sediment } \\
\text { concentrations }^{\mathrm{a}}\end{array}$ & $\begin{array}{l}\text { Primary method of } \\
\text { suspended-sediment } \\
\text { data collection } \\
\text { (EDI, EWI, multiple } \\
\text { vertical/ DI, PS) }\end{array}$ & $\begin{array}{c}\text { Primary } \\
\text { Sampler type }\end{array}$ & $\begin{array}{c}\text { Streamflow- } \\
\text { weighted mean } \\
\text { suspended-sediment } \\
\text { concentration }(\mathrm{mg} / \mathrm{L})^{b}\end{array}$ & $\begin{array}{c}\text { Annual mean } \\
\text { streamflow }\left(\mathrm{ft}^{3} / \mathbf{s}\right)^{\mathrm{c}}\end{array}$ \\
\hline \multicolumn{6}{|c|}{06934500 Missouri River at Hermann, Missouri } \\
\hline 1976 & 45 & \multirow{13}{*}{ EDI/DI, PS } & \multirow{13}{*}{ US P-61, US P-63 } & 545 & 68,900 \\
\hline 1977 & 38 & & & 477 & 56,700 \\
\hline 1978 & 49 & & & 694 & 97,200 \\
\hline 1979 & 41 & & & 791 & 91,300 \\
\hline 1980 & 52 & & & 605 & 63,000 \\
\hline 1981 & 50 & & & 960 & 65,700 \\
\hline 1982 & 15 & & & 1,250 & 100,000 \\
\hline 1983 & 15 & & & 1,290 & 120,000 \\
\hline 1984 & 20 & & & 1,060 & 127,000 \\
\hline 1985 & 22 & & & 747 & 106,000 \\
\hline 1986 & 23 & & & 747 & 112,000 \\
\hline 1987 & 21 & & & 960 & 127,000 \\
\hline 1988 & 21 & & & 480 & 66,000 \\
\hline 1989 & 16 & \multirow{16}{*}{ EWI, EDI/DI, PS } & \multirow{16}{*}{ US P-61, US P-63 } & 504 & 52,000 \\
\hline 1990 & 14 & & & 1,460 & 78,700 \\
\hline 1991 & 17 & & & 602 & 55,700 \\
\hline 1992 & 10 & & & 811 & 67,100 \\
\hline 1993 & 17 & & & 989 & 182,000 \\
\hline 1994 & 12 & & & 538 & 110,000 \\
\hline 1995 & 15 & & & 844 & 124,000 \\
\hline 1996 & 24 & & & 650 & 99,200 \\
\hline 1997 & 25 & & & 799 & 122,000 \\
\hline 1998 & 28 & & & 653 & 117,000 \\
\hline 1999 & 27 & & & 826 & 136,000 \\
\hline 2000 & 30 & & & 248 & 57,800 \\
\hline 2001 & 31 & & & 826 & 85,200 \\
\hline 2002 & 29 & & & 712 & 63,900 \\
\hline 2003 & 22 & & & 259 & 45,100 \\
\hline 2004 & 30 & & & 601 & 68,500 \\
\hline 2005 & 15 & \multirow{4}{*}{ EWI, EDI/DI } & \multirow{4}{*}{ D-96 } & 718 & 73,400 \\
\hline 2006 & 14 & & & 216 & 41,700 \\
\hline 2007 & 14 & & & 465 & 79,100 \\
\hline 2008 & 12 & & & 783 & 115,000 \\
\hline
\end{tabular}

${ }^{a}$ Number of samples based on data available in USGS NWIS database as of 5/20/2010 .

${ }^{\mathrm{b}}$ Annual streamflow-weighted mean suspended-sediment concentration calculated by dividing annual suspended-sediment load (table 3 ) by annual mean streamflow.

${ }^{\mathrm{c}}$ Source: U.S. Geological Survey (2009). 
samples comprising a sample were averaged to obtain a single mean concentration and particle-size fraction (if available) for a given sample date. Suspended-sand concentrations were determined by multiplying the suspended-sediment load by the corresponding sand fraction. If concurrent depth-integrated and point sample data were available for the same sample date only the depth-integrated samples were used in sediment-load computations. The computed point sample averages only were used to supplement missing depth-integrated data.

Depth-integrated sample averages were computed using a simple arithmetic average, whereas the method of determining the average of the point-sample concentrations and size fractions varied by site. Point samples were available for the Missouri River mainstem stations at Sioux City, Iowa (station 06486000) ; Omaha, Nebraska (station 06610000), Nebraska City, Nebraska (station 06807000); Saint Joseph (station 06818000), Kansas City (station 06893000), and Hermann (station 06934500), Missouri; and for the Kansas River near Desoto, Kansas (station 06892350). When available, a comparison of concurrent depth-integrated and point-sample SSCs was used to determine the method (for example, discharge weighted, area weighted, velocity weighted, arithmetic average, or average of samples collected at 20, 50 , and 80 percent fractions of total depths) that provided the best agreement [lowest root mean square error (RMSE)] between the averaged point sample values and the depthintegrated values. Archived sediment records from the USACE indicated that the velocity-weighted (U.S. Army Corps of Engineers, unpub. data, 1966) and discharge-weighted (U.S. Army Corps of Engineers, unpub. data, 1973-75) approaches historically had been used in comparisons of point-sample and depth-integrated SSCs. A sub-sample of SSCs from 100 concurrent depth-integrated and point-sampled verticals from the Missouri River at Saint Joseph (station 06818000; 1951-2004), Kansas City (station 06893000; 1948-2004), and Hermann (station 06934500; 1972-2004), Missouri stations, were used to determine the averaging method that provided the best agreement between depth-integrated and point-sample SSC averages. The velocity-weighted average of point samples provided the best agreement with depthintegrated samples at the Missouri River at Saint Joseph [station 06818000; lowest RMSE of 374 milligrams per liter (mg/L)] and Kansas City, Missouri (station 06893000; lowest RMSE of $237 \mathrm{mg} / \mathrm{L}$ ) stations, whereas the average of the point samples collected at the 20,50, and 80-percent fractions of total depth provided the best agreement (lowest RMSE of $129 \mathrm{mg} / \mathrm{L}$ ) at Hermann, Missouri (station 06934500; except for concentrations greater than $2,000 \mathrm{mg} / \mathrm{L}$ in which case the velocity-weighted samples provided the best agreement). Concurrent depth-integrated and point-sample SSCs were not available for the Missouri River stations at Sioux City, Iowa, Omaha, Nebraska, Nebraska City, Nebraska (1977-91) or the Kansas River near Desoto, Kansas (1976-82) and, therefore, the velocity-weighted averaging approach was selected to determine average point-sample SSCs at these stations.

\section{Turbidity and Streamflow}

Additional USGS NWIS data used in the computation of suspended-sediment and suspended sand loads included instantaneous turbidity values and daily streamflow. Turbidity data were collected using submersible-type nephelometric sensors and the methods used in the collection of these data are described in Wagner and others (2006). Daily mean streamflows also were retrieved from NWIS and used in the computation of annual suspended-sediment and suspendedsand loads. Instantaneous (usually hourly) turbidity and streamflow values were used in the computation of annual suspended-sediment loads at five stations and these data were available in the NWIS database (US Geological Survey, 2009) and at http://nrtwq.usgs.gov.

\section{Methods of Sediment Load Estimation}

Annual suspended-sediment and suspended-sand loads provided in this report were determined using three techniques: (1) the subdivision method; (2) regression of instantaneous turbidity with SSC values at select stations; or (3) by the Load Estimator (LOADEST) regression technique (Runkel and others, 2004). A description of the methods used in the determination of total suspended-sediment and suspended-sand loads follows.

\section{Subdivision Method}

The subdivision (Porterfield, 1972) or "day to day" method was used for the computation of all reported published and unpublished sediment loads provided in this report. Suspended sediment loads were computed using the subdivision method by the USGS at the Missouri River Sioux City, Iowa (station 06486000) ; Omaha, Nebraska (station 06610000), Nebraska City, Nebraska (station 06807000); (Joseph Gorman, U.S. Geological Survey, written commun., 2010). The sediment loads at the Nodaway River at Clarinda, Iowa station from 1976-92 also were computed by the USGS using the subdivision method. In this method a daily observed or estimated SSC is multiplied by the corresponding daily streamflow to obtain a daily load. A continual trace of SSCs is developed for the period of interest using sampled SSCs and estimates of SSCs for intervals between times of sample collection. These estimates were made using a relation of discharge to SSC known as a sediment-rating (sediment transport) curve as described by Horowitz (2003). From 1998- 2001 the computation of sediment loads at these stations was facilitated using the software Sediment-Record Calculations (SEDCALC; Koltun and others, 1994) and for 2002-08 the suspended-sediment loads were determined using the software Graphical Constituent Loading Analysis System (GCLAS; Koltun and others, 2006). The method used by the USACE for the 1976-81 suspended-sediment 
and suspended-sand loads at the Missouri River at Saint Joseph (station 06818000), Kansas City (station 06893000), and Hermann (station 06934500), Missouri stations was not specified but likely was the subdivision method as it was used in load calculations by the USACE between 1937-1974 (U.S. Army Corps of Engineers, 1951, 1957, 1965, 1970, 1972, 1976).

\section{Regression of Turbidity with Suspended Sediment}

A second method used in the computation of annual suspended-sediment loads for five Missouri River mainstem stations for 2006-08 was a regression model determined from instantaneous turbidity and SSC values. Missouri River stations for which turbidity record was used in load computation included Yankton, South Dakota, Council Bluffs, Iowa (station 06610505), Nebraska City, Nebraska (station 06807000), Saint Joseph (station 06818000), and Hermann (station 06934500), Missouri. A detailed description of the technique is provided in Rasmussen and others (2009). A linear regression model was developed between observed instantaneous turbidity data and SSC values collected during 2006 through 2008. Outliers in the turbidity -SSC relation were identified as any data point with a regression residual greater than 1.5 times the interquartile range (central $50^{\text {th }}$ percentile of the data distribution) of all the residuals. After identification, the outlier was evaluated for leverage. If an outlier significantly affected the slope or intercept of a regression, it was removed (filtered) from the regression analysis (fig. 2).

Transformation of the variables was explored to ensure that the residuals met the assumed characteristics of linear regression. This was determined by the distribution of the data on an plot of turbidity and SSC. Regressions developed from log-log transformed data often were skewed negatively for high turbidity values. Despite heteroscedastic residual distribution, and in some cases, a slightly larger estimate of error, a single site-specific model was developed from non-transformed data to better represent the high end of the turbidity-SSC relation (fig. 2).

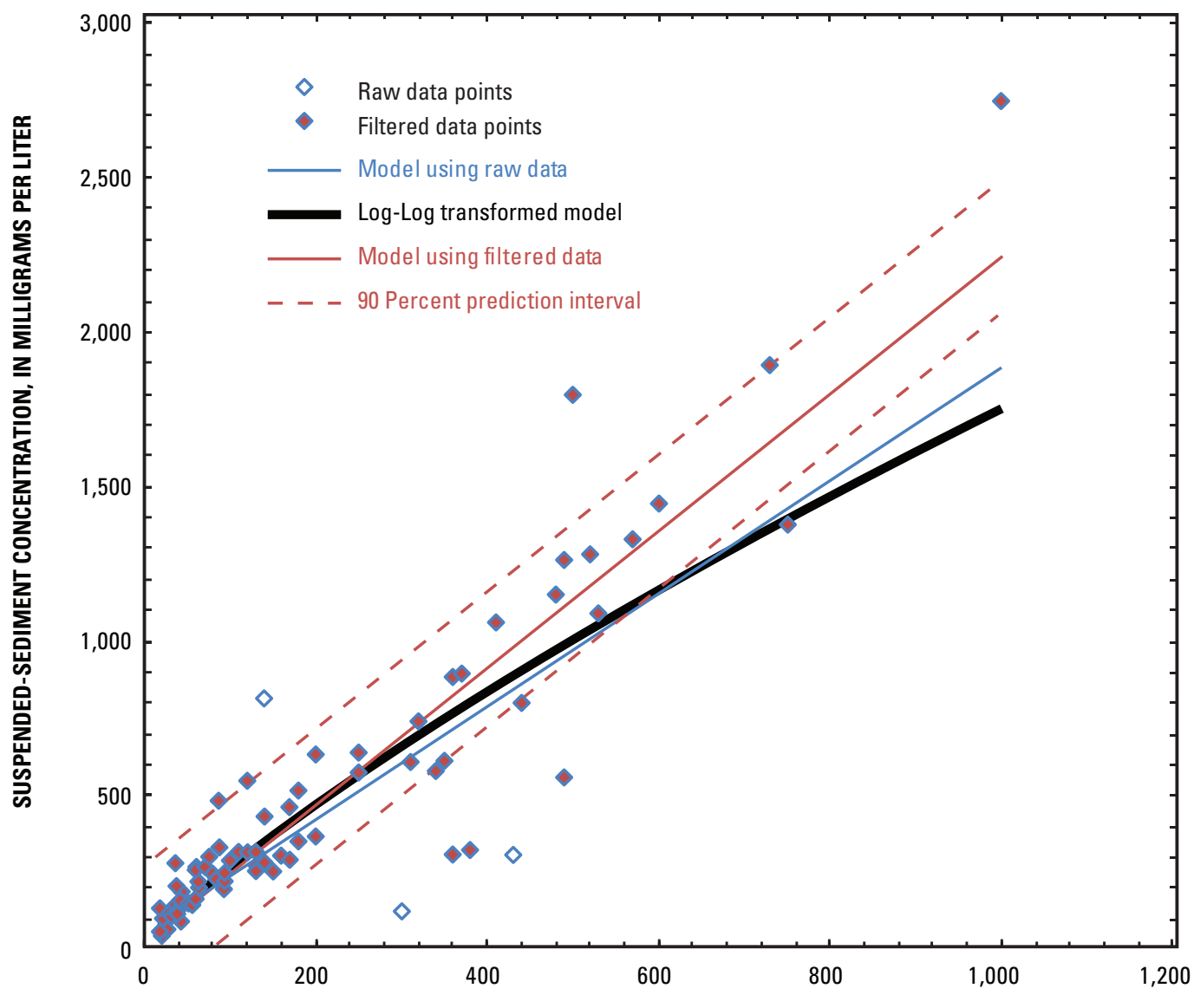

Figure 2. Comparison of turbidity to suspendedsediment concentration in water from U.S. Geological Survey streamgage on Missouri River at Hermann (station 06934500), Missouri, October 2004October 2009. 
For periods when turbidity values were unavailable or were truncated [values greater than 1200 Formazin Nephelometric Units (FNU)] as a result of high SSC values, SSC was estimated using a sediment rating developed from streamflow. Streamflow-estimated SSC typically has a greater estimated uncertainty (Walling, 1977) and rarely matches with turbidity-estimated SSC. To account for this, a shift was applied to the streamflow-estimated SSC to match the turbidity-estimated SSC value at the start and end points of the missing periods. This estimation method is very similar to the subdivision method described in Porterfield (1972).

Resulting SSC models and model calibration data developed from the observed turbidity-SSC pairs can be found at http://nrtwq.usgs.gov/explore/modelinfo? site $n o=06467500 \&$ pcode $=99409$ SED $15 \&$ period $=2009$ all\&timestep $=u v$ for the Missouri River at Yankton, South Dakota (station 06467500); http://nrtwq.usgs.gov/explore/ modelinfo? site_no $=06610505 \&$ pcode $=99409$ SED15\&pe riod $=2009$ all\&timestep $=u v$ for the Missouri River near Council Bluffs, Iowa (station 06610505), http://nrtwq.usgs. gov/explore/modelinfo? site_no $=06807000 \& p$ code $=99409 S E$ D15\&period $=2007$ all\&timestep $=u v$ for the Missouri River at Nebraska City, Nebraska (station 06807000), http://nrtwq. usgs.gov/explore/modelinfo? site_no $=06818000 \& p$ code $=99$ 409SED15\&period $=2007$ all\&timestep $=u v$ for the Missouri River at St. Joseph, Missouri (station 06818000), and http:// nrtwq.usgs.gov/explore/modelinfo? site_no $=06934500 \& p c$ ode $=99409$ SED $15 \&$ period $=2007$ all\&timestep $=u v$ for the Missouri River at Hermann, Missouri (station 06934500). Station-specific hourly SSC, and hourly, monthly, and annual suspended-sediment loads also are provided.

\section{Load Estimator (LOADEST)}

A third method of the determination of suspendedsediment and suspended-sand loads was by means of regression techniques using the computer program LOADEST (Runkel and others, 2004). More specifically, the S-LOADEST version of the program written for the commercial statistical package TIBCO Spotfire S+ (TIBCO Software Inc., version 8.1) was used in the sediment load estimates. LOADEST incorporates explanatory variables of streamflow (either a linear or quadratic relation), time (either a linear or quadratic relation), and season into one of nine predefined regression models. These models were fit to observed streamflow-SSC or streamflow-suspended sand concentration data pairs using adjusted-maximumlikelihood-estimation (AMLE) techniques (Cohn, 1988) or, more specifically, the maximum likelihood estimation (MLE) method since the dataset was uncensored (Cohn and others, 1992). Streamflow, suspended-sediment and suspendedsand concentration data used in the LOADEST models are summarized by site in appendix 1 . Model fit was judged using the Akaike Information Criterion (AIC) (Judge and others, 1988). Both the AMLE and MLE methods are contingent upon the assumption that model residuals were normally distributed and this was assessed by means of the TurnbullWeiss likelihood ratio (Turnbull and Weiss, 1978) within S-LOADEST. About 14 percent of models selected using the AIC did not meet the normality assumption and in these cases the Least Absolute Deviation (LAD) model technique was used in lieu of the AMLE technique as LAD load estimates are not dependent on the normality assumption. Once a model was selected, loads were determined using a specified time series of daily streamflow. LOADEST output consisted of a mean load, 95-percent confidence-interval estimates of mean load, standard error of prediction, and total load for any specified time interval. In addition to the standard LOADEST statistical output, the coefficient of variation $(\mathrm{CV})$ or "relative variability" for each LOADEST model also was computed as the ratio of the standard error of prediction and mean load. A dimensionless value expressed as a percent, the model CV provides an indication of the relative error in model prediction. The lower the CV computed, the lower the relative error in model prediction. LOADEST output for the LAD models did not include the 95-percent confidence interval estimates of mean load or standard error of prediction, and, therefore, $\mathrm{CV}$ values were not determined for the LAD models.

Rather than developing a single model to estimate loads for the range of available sediment concentrations at a particular station, sediment-load models were developed using a moving window approach. The load model for a given year was computed using 3,5 , or 7 years of total suspendedsediment or suspended-sand concentration data centered about the year of interest. The computation window interval varied depending on sediment data availability. The minimum computation window of 3 years was used whenever possible. This approach allowed for the incorporation of short term (3 to 7 year) changes in the sediment transport-streamflow relation, while including sufficient model-calibration data from adjacent years to meet LOADEST minimum data input requirements, and extend the range of streamflows represented by the observed suspended-sediment concentrations.

\section{Annual Suspended-Sediment Loads and Yields}

Annual suspended-sediment and suspended-sand load estimates (in tons) at 18 selected stations in the lower Missouri River Basin for the period encompassing 1976- 2008 are presented in table 3. Annual suspended-sediment and suspended-sand yield estimates, computed as load per unit area (tons per square mile), are given in table 4 . The time periods used for the summary statistics of the annual load estimates vary by station because they are limited to available data. The time periods can be inferred by inspecting data availability in table 1 . 
Table 3. Annual suspended-sediment and suspended-sand loads, and annual LOADEST model characteristics, for selected sediment stations in the lower Missouri River Basin, 1976-2008.

$\left[\mathrm{r}^{2}\right.$, regression model coefficient of determination; --, no data or not applicable; >, greater than; mm, millimeters]

\begin{tabular}{|c|c|c|c|c|c|c|c|c|c|c|c|}
\hline $\begin{array}{l}\text { Water } \\
\text { Year }\end{array}$ & Load (tons) & $\begin{array}{l}\text { LOADEST } \\
\text { model } r^{2}\end{array}$ & & $\begin{array}{c}\text { Lower } \\
\text { 95-percent } \\
\text { confidence } \\
\text { interval of } \\
\text { LOADEST } \\
\text { load estimate } \\
\text { (tons) }\end{array}$ & $\begin{array}{c}\text { Upper } \\
\text { 95-percent } \\
\text { confidence } \\
\text { interval of } \\
\text { LOADEST } \\
\text { load estimate } \\
\text { (tons) }\end{array}$ & $\begin{array}{c}\text { Percent } \\
\text { of total } \\
\text { suspended- } \\
\text { sediment } \\
\text { load as sand } \\
(>0.0625 \mathrm{~mm})^{\mathrm{b}}\end{array}$ & $\begin{array}{c}\text { Annual } \\
\text { suspended } \\
\text { load (tons) }\end{array}$ & $\begin{array}{c}\text { LOADEST } \\
\text { model } \mathbf{r}^{2}\end{array}$ & $\begin{array}{l}\text { LOADEST } \\
\text { model } \\
\text { coefficient } \\
\text { of variation } \\
\text { (percent) }\end{array}$ & $\begin{array}{c}\text { Lower } \\
\text { 95-percent } \\
\text { confidence } \\
\text { interval of } \\
\text { LOADEST } \\
\text { load } \\
\text { estimate } \\
\text { (tons) }\end{array}$ & $\begin{array}{c}\text { Upper } \\
\text { 95-percent } \\
\text { confidence } \\
\text { interval of } \\
\text { LOADEST load } \\
\text { estimate (tons) }\end{array}$ \\
\hline \multicolumn{12}{|c|}{06467500 Missouri River at Yankton, South Dakota } \\
\hline 2001 & 271,000 & 78 & 20 & 179,000 & 393,000 & -- & -- & -- & -- & -- & -- \\
\hline 2002 & 231,000 & 78 & 14 & 174,000 & 302,000 & -- & -- & -- & -- & -- & -- \\
\hline 2003 & 241,000 & 75 & 15 & 177,000 & 320,000 & -- & -- & -- & -- & -- & -- \\
\hline 2004 & 284,000 & 82 & 17 & 199,000 & 392,000 & -- & -- & -- & -- & -- & -- \\
\hline 2005 & 282,000 & 71 & 22 & 182,000 & 419,000 & -- & -- & -- & -- & -- & -- \\
\hline 2006 & $\begin{array}{r}220,000 \\
{[222,000]^{\mathrm{c}}}\end{array}$ & 57 & 16 & 158,000 & 299,000 & -- & -- & -- & -- & -- & -- \\
\hline 2007 & $\begin{array}{r}163,000 \\
{[214,000]^{\mathrm{c}}}\end{array}$ & 53 & 15 & 120,000 & 216,000 & -- & -- & -- & -- & -- & -- \\
\hline 2008 & $\begin{array}{r}153,000 \\
{[183,000]^{\mathrm{c}}} \\
\end{array}$ & 53 & 15 & 113,350 & 203,000 & -- & -- & -- & -- & -- & -- \\
\hline \multicolumn{12}{|c|}{06478500 James River at Scotland, South Dakota } \\
\hline 1976 & 26,700 & 98 & 6 & 21,800 & 27,800 & -- & -- & -- & -- & -- & -- \\
\hline 1977 & 14,400 & 98 & 8 & 12,200 & 16,800 & -- & -- & -- & -- & -- & -- \\
\hline 1978 & 100,000 & 98 & 9 & 84,700 & 118,000 & -- & -- & -- & -- & -- & -- \\
\hline 1979 & 64,700 & 98 & 8 & 55,400 & 75,100 & -- & -- & -- & -- & -- & -- \\
\hline 1980 & 12,700 & 95 & 10 & 10,300 & 15,400 & -- & -- & -- & -- & -- & -- \\
\hline 1981 & 2,170 & 93 & 12 & 1,690 & 2,740 & -- & -- & -- & -- & -- & -- \\
\hline 1982 & 41,100 & 94 & 25 & 24,500 & 64,900 & -- & -- & -- & -- & -- & -- \\
\hline 1983 & 129,000 & -- & -- & -- & -- & -- & -- & -- & -- & -- & -- \\
\hline 1984 & 278,000 & 92 & 23 & 174,000 & 422,000 & -- & -- & -- & -- & -- & -- \\
\hline
\end{tabular}




\begin{tabular}{|c|c|c|c|c|c|c|c|c|c|c|c|}
\hline $\begin{array}{l}\text { Water } \\
\text { Year }\end{array}$ & Load (tons) & $\begin{array}{l}\text { LOADEST } \\
\text { model } r^{2}\end{array}$ & $\begin{array}{l}\text { LOADEST } \\
\text { model } \\
\text { coefficient } \\
\text { of } \\
\text { variation }^{\mathrm{a}} \\
\text { (percent) } \\
\end{array}$ & $\begin{array}{c}\text { Lower } \\
\text { 95-percent } \\
\text { confidence } \\
\text { interval of } \\
\text { LOADEST } \\
\text { load } \\
\text { estimate } \\
\text { (tons) }\end{array}$ & $\begin{array}{c}\text { Upper } \\
\text { 95-percent } \\
\text { confidence } \\
\text { interval of } \\
\text { LOADEST } \\
\text { load estimate } \\
\text { (tons) }\end{array}$ & $\begin{array}{l}\text { Percent of total } \\
\text { suspended- } \\
\text { sediment } \\
\text { load as sand } \\
(>0.0625 \mathrm{~mm})^{\mathrm{b}}\end{array}$ & $\begin{array}{c}\text { Annual } \\
\text { suspended } \\
\text { load (tons) }\end{array}$ & $\begin{array}{l}\text { LOADEST } \\
\text { model } r^{2}\end{array}$ & $\begin{array}{l}\text { LOADEST } \\
\text { model } \\
\text { coefficient } \\
\text { of variation } \\
\text { (percent) }\end{array}$ & $\begin{array}{c}\text { Lower } \\
\text { 95-percent } \\
\text { confidence } \\
\text { interval of } \\
\text { LOADEST } \\
\text { load } \\
\text { estimate } \\
\text { (tons) }\end{array}$ & $\begin{array}{c}\text { Upper } \\
\text { 95-percent } \\
\text { confidence } \\
\text { interval of } \\
\text { LOADEST load } \\
\text { estimate (tons) }\end{array}$ \\
\hline \multicolumn{12}{|c|}{06478500 James River at Scotland, South Dakota-Continued } \\
\hline 1985 & 64,300 & -- & -- & -- & -- & -- & -- & -- & -- & -- & -- \\
\hline 1986 & 317,000 & -- & -- & -- & -- & -- & -- & -- & -- & -- & -- \\
\hline 1987 & 110,000 & -- & -- & -- & -- & -- & -- & -- & -- & -- & -- \\
\hline 1988 & 13,700 & 96 & 19 & 9,290 & 19,600 & -- & -- & -- & -- & -- & -- \\
\hline 1989 & 13,400 & 93 & 22 & 8,660 & 20,000 & -- & -- & -- & -- & -- & -- \\
\hline 1990 & 9,090 & 94 & 18 & 6,250 & 12,800 & -- & -- & -- & -- & -- & -- \\
\hline 1991 & 34,800 & 94 & 21 & 22,400 & 51,500 & -- & -- & -- & -- & -- & -- \\
\hline 1992 & 22,500 & 96 & 16 & 16,200 & 30,600 & -- & -- & -- & -- & -- & -- \\
\hline 1993 & 189,000 & -- & -- & -- & -- & -- & -- & -- & -- & -- & -- \\
\hline 1994 & 160,000 & 96 & 15 & 118,000 & 211,000 & -- & -- & -- & -- & -- & -- \\
\hline 1995 & 366,000 & 93 & 27 & 212,000 & 591,000 & -- & -- & -- & -- & -- & -- \\
\hline \multicolumn{12}{|c|}{06485500 Big Sioux River at Akron, lowa } \\
\hline 1976 & 99,200 & 95 & 18 & 69,200 & 138,000 & -- & -- & -- & -- & -- & -- \\
\hline 1977 & 63,500 & 93 & 19 & 42,800 & 90,800 & -- & -- & -- & -- & -- & -- \\
\hline 1978 & 510,000 & 94 & 19 & 348,000 & 717,000 & -- & -- & -- & -- & -- & -- \\
\hline 1979 & 629,000 & -- & -- & -- & -- & -- & -- & -- & -- & -- & -- \\
\hline 1980 & 614,000 & -- & -- & -- & -- & -- & -- & -- & -- & -- & -- \\
\hline 1981 & 205,000 & -- & -- & -- & -- & -- & -- & -- & -- & -- & -- \\
\hline 1982 & 368,000 & 77 & 39 & 163,000 & 721,000 & -- & -- & -- & -- & -- & -- \\
\hline 1983 & $1,600,000$ & 74 & 95 & 242,000 & $5,570,000$ & -- & -- & -- & -- & -- & -- \\
\hline
\end{tabular}


Table 3. Annual suspended-sediment and suspended-sand loads, and annual LOADEST model characteristics, for selected sediment stations in the lower Missouri River Basin, 1976-2008-Continued

$\left[\mathrm{r}^{2}\right.$, regression model coefficient of determination; --, no data or not applicable; >, greater than; mm, millimeters]

\begin{tabular}{|c|c|c|c|c|c|c|c|c|c|c|c|}
\hline $\begin{array}{c}\text { Water } \\
\text { Year }\end{array}$ & Load (tons) & $\begin{array}{l}\text { LOADEST } \\
\text { model } r^{2}\end{array}$ & $\begin{array}{l}\text { LOADEST } \\
\text { model } \\
\text { coefficient } \\
\text { of } \\
\text { variation } \\
\text { (percent) }^{\mathrm{a}} \\
\end{array}$ & $\begin{array}{c}\text { Lower } \\
\text { 95-percent } \\
\text { confidence } \\
\text { interval of } \\
\text { LOADEST } \\
\text { load } \\
\text { estimate } \\
\text { (tons) }\end{array}$ & $\begin{array}{c}\text { Upper } \\
\text { 95-percent } \\
\text { confidence } \\
\text { interval of } \\
\text { LOADEST } \\
\text { load estimate } \\
\text { (tons) } \\
\end{array}$ & $\begin{array}{l}\text { Percent of total } \\
\text { suspended- } \\
\text { sediment } \\
\text { load as sand } \\
(>0.0625 \mathrm{~mm})^{\mathrm{b}}\end{array}$ & $\begin{array}{c}\text { Annual } \\
\text { suspended } \\
\text { load (tons) }\end{array}$ & $\begin{array}{l}\text { LOADEST } \\
\text { model } r^{2}\end{array}$ & $\begin{array}{l}\text { LOADEST } \\
\text { model } \\
\text { coefficient } \\
\text { of variation } \\
\text { (percent) }\end{array}$ & $\begin{array}{c}\text { Lower } \\
\text { 95-percent } \\
\text { confidence } \\
\text { interval of } \\
\text { LOADEST } \\
\text { load } \\
\text { estimate } \\
\text { (tons) }\end{array}$ & $\begin{array}{c}\text { Upper } \\
\text { 95-percent } \\
\text { confidence } \\
\text { interval of } \\
\text { LOADEST load } \\
\text { estimate (tons) }\end{array}$ \\
\hline \multicolumn{12}{|c|}{06485500 Big Sioux River at Akron, lowa-Continued } \\
\hline 1984 & $3,120,000$ & 88 & 44 & $1,240,000$ & $6,550,000$ & -- & -- & -- & -- & -- & -- \\
\hline 1985 & 788,000 & 86 & 33 & 402,000 & $1,400,000$ & -- & -- & -- & -- & -- & -- \\
\hline 1986 & $2,410,000$ & 87 & 45 & 957,000 & $5,070,000$ & -- & -- & -- & -- & -- & -- \\
\hline 1987 & 688,000 & 86 & 33 & 350,000 & $1,220,000$ & -- & -- & -- & -- & -- & -- \\
\hline 1988 & 240,000 & 86 & 33 & 141,000 & 383,000 & -- & -- & -- & -- & -- & -- \\
\hline 1989 & 148,000 & 91 & 24 & 91,100 & 228,000 & -- & -- & -- & -- & -- & -- \\
\hline 1990 & 199,000 & 91 & 24 & 121,000 & 308,000 & -- & -- & -- & -- & -- & -- \\
\hline 1991 & 163,000 & 93 & 21 & 106,000 & 240,000 & -- & -- & -- & -- & -- & -- \\
\hline 1992 & 608,000 & 93 & 21 & 400,000 & 888,000 & -- & -- & -- & -- & -- & -- \\
\hline 1993 & $4,680,000$ & 93 & 34 & $2,320,000$ & $8,480,000$ & -- & -- & -- & -- & -- & -- \\
\hline 1994 & $1,420,000$ & 93 & 23 & 881,000 & $2,170,000$ & -- & -- & -- & -- & -- & -- \\
\hline \multicolumn{12}{|c|}{06486000 Missouri River at Sioux City, lowa } \\
\hline 1976 & $19,400,000^{d}$ & -- & -- & -- & -- & -- & -- & -- & -- & -- & -- \\
\hline 1977 & $11,500,000$ & -- & -- & -- & -- & -- & -- & -- & -- & -- & -- \\
\hline 1978 & $13,800,000$ & 62 & 15 & $10,100,000$ & $18,400,000$ & -- & -- & -- & -- & -- & -- \\
\hline 1979 & $19,300,000$ & -- & -- & -- & -- & -- & -- & -- & -- & -- & -- \\
\hline 1980 & $10,600,000$ & 75 & 8 & $9,040,000$ & $12,500,000$ & -- & -- & -- & -- & -- & -- \\
\hline
\end{tabular}




\begin{tabular}{|c|c|c|c|c|c|c|c|c|c|c|c|}
\hline $\begin{array}{c}\text { Water } \\
\text { Year }\end{array}$ & Load (tons) & $\begin{array}{l}\text { LOADEST } \\
\text { model } r^{2}\end{array}$ & $\begin{array}{c}\text { LOADEST } \\
\text { model } \\
\text { coefficient } \\
\text { of } \\
\text { variation } \\
\text { (percent) }\end{array}$ & $\begin{array}{c}\text { Lower } \\
\text { 95-percent } \\
\text { confidence } \\
\text { interval of } \\
\text { LOADEST } \\
\text { Ioad } \\
\text { estimate } \\
\text { (tons) }\end{array}$ & $\begin{array}{c}\text { Upper } \\
\text { 95-percent } \\
\text { confidence } \\
\text { interval of } \\
\text { LOADEST } \\
\text { load estimate } \\
\text { (tons) }\end{array}$ & $\begin{array}{l}\text { Percent of total } \\
\text { suspended- } \\
\text { sediment } \\
\text { load as sand } \\
(>0.0625 \mathrm{~mm})^{\mathrm{b}}\end{array}$ & $\begin{array}{c}\text { Annual } \\
\text { suspended } \\
\text { load (tons) }\end{array}$ & $\begin{array}{l}\text { LOADEST } \\
\text { model } r^{2}\end{array}$ & $\begin{array}{c}\text { LOADEST } \\
\text { model } \\
\text { coefficient } \\
\text { of variation } \\
\text { (percent) }\end{array}$ & $\begin{array}{c}\text { Lower } \\
\text { 95-percent } \\
\text { confidence } \\
\text { interval of } \\
\text { LOADEST } \\
\text { load } \\
\text { estimate } \\
\text { (tons) }\end{array}$ & $\begin{array}{c}\text { Upper } \\
\text { 95-percent } \\
\text { confidence } \\
\text { interval of } \\
\text { LOADEST load } \\
\text { estimate (tons) }\end{array}$ \\
\hline \multicolumn{12}{|c|}{06486000 Missouri River at Sioux City, lowa - Continued } \\
\hline 1981 & $10,900,000$ & 61 & 11 & $8,750,000$ & $13,400,000$ & 64 & $7,010,000$ & 69 & 9 & $5,830,000$ & $8,370,000$ \\
\hline 1982 & $7,880,000$ & 61 & 10 & $6,500,000$ & $9,460,000$ & 73 & $5,740,000$ & 69 & 12 & $4,540,000$ & $7,180,000$ \\
\hline 1983 & $15,400,000$ & -- & -- & -- & -- & 62 & $9,570,000$ & 79 & 8 & $8,110,000$ & $11,200,000$ \\
\hline 1984 & $18,800,000$ & -- & -- & -- & -- & 50 & $9,410,000$ & 80 & 6 & $8,280,000$ & $10,700,000$ \\
\hline 1985 & $15,200,000$ & 77 & 11 & $11,200,000$ & $20,100,000$ & 57 & $7,450,000$ & 85 & 8 & $6,370,000$ & $8,660,000$ \\
\hline 1986 & $12,100,000$ & 75 & 6 & $10,600,000$ & $13,600,000$ & 61 & $7,400,000$ & 80 & 7 & $6,480,000$ & $8,410,000$ \\
\hline 1987 & $9,890,000$ & 70 & 5 & $8,970,000$ & $10,900,000$ & 78 & $7,690,000$ & 73 & 12 & $6,040,000$ & $9,650,000$ \\
\hline 1988 & $8,190,000$ & 62 & 7 & $7,130,000$ & $9,350,000$ & 68 & $5,540,000$ & -- & -- & -- & -- \\
\hline 1989 & $6,200,000$ & 76 & 6 & $5,540,000$ & $6,910,000$ & 62 & $3,840,000$ & -- & -- & -- & -- \\
\hline 1990 & $3,630,000$ & 76 & 4 & $3,340,000$ & $3,930,000$ & 61 & $2,220,000$ & -- & -- & -- & -- \\
\hline 1991 & $3,930,000$ & 76 & 3 & $3,720,000$ & $4,140,000$ & 54 & $2,120,000$ & -- & -- & -- & -- \\
\hline 1992 & $4,680,000^{\mathrm{d}}$ & -- & -- & -- & -- & -- & -- & -- & -- & -- & -- \\
\hline 1993 & $8,700,000^{\mathrm{d}}$ & -- & -- & -- & -- & & -- & -- & -- & -- & -- \\
\hline 1994 & $6,460,000^{\mathrm{d}}$ & -- & -- & -- & -- & -- & -- & -- & -- & -- & -- \\
\hline 1995 & $9,700,000^{\mathrm{d}}$ & -- & -- & -- & -- & -- & -- & -- & -- & -- & -- \\
\hline 1996 & $15,000,000^{\mathrm{d}}$ & -- & -- & -- & -- & -- & -- & -- & -- & -- & -- \\
\hline 1997 & $20,800,000^{\mathrm{d}}$ & -- & -- & -- & -- & -- & -- & -- & -- & -- & -- \\
\hline 1998 & $12,100,000^{\mathrm{d}}$ & -- & -- & -- & -- & -- & -- & -- & -- & -- & -- \\
\hline 1999 & $9,530,000^{\mathrm{d}}$ & -- & -- & -- & -- & -- & -- & -- & -- & -- & -- \\
\hline
\end{tabular}


Table 3. Annual suspended-sediment and suspended-sand loads, and annual LOADEST model characteristics, for selected sediment stations in the lower Missouri River Basin, 1976-2008-Continued

$\left[\mathrm{r}^{2}\right.$, regression model coefficient of determination; --, no data or not applicable; >, greater than; mm, millimeters]

\begin{tabular}{|c|c|c|c|c|c|c|c|c|c|c|c|}
\hline $\begin{array}{c}\text { Water } \\
\text { Year }\end{array}$ & Load (tons) & $\begin{array}{l}\text { LOADEST } \\
\text { model } r^{2}\end{array}$ & $\begin{array}{l}\text { LOADEST } \\
\text { model } \\
\text { coefficient } \\
\text { of } \\
\text { variation }^{\text {a }} \\
\text { (percent) }^{-}\end{array}$ & $\begin{array}{c}\text { Lower } \\
\text { 95-percent } \\
\text { confidence } \\
\text { interval of } \\
\text { LOADEST } \\
\text { load } \\
\text { estimate } \\
\text { (tons) }\end{array}$ & $\begin{array}{c}\text { Upper } \\
\text { 95-percent } \\
\text { confidence } \\
\text { interval of } \\
\text { LOADEST } \\
\text { load estimate } \\
\text { (tons) } \\
\end{array}$ & $\begin{array}{l}\text { Percent of total } \\
\text { suspended- } \\
\text { sediment } \\
\text { load as sand } \\
(>0.0625 \mathrm{~mm})^{\mathrm{b}}\end{array}$ & $\begin{array}{c}\text { Annual } \\
\text { suspended } \\
\text { load (tons) }\end{array}$ & $\begin{array}{l}\text { LOADEST } \\
\text { model } r^{2}\end{array}$ & $\begin{array}{l}\text { LOADEST } \\
\text { model } \\
\text { coefficient } \\
\text { of variation } \\
\text { (percent) }\end{array}$ & $\begin{array}{c}\text { Lower } \\
\text { 95-percent } \\
\text { confidence } \\
\text { interval of } \\
\text { LOADEST } \\
\text { load } \\
\text { estimate } \\
\text { (tons) }\end{array}$ & $\begin{array}{c}\text { Upper } \\
\text { 95-percent } \\
\text { confidence } \\
\text { interval of } \\
\text { LOADEST load } \\
\text { estimate (tons) }\end{array}$ \\
\hline \multicolumn{12}{|c|}{06486000 Missouri River at Sioux City, lowa-Continued } \\
\hline 2000 & $6,970,000^{\mathrm{d}}$ & -- & -- & -- & -- & -- & -- & -- & -- & -- & -- \\
\hline 2004 & $4,350,000^{\mathrm{d}}$ & -- & -- & -- & -- & -- & -- & -- & -- & -- & -- \\
\hline 2005 & $3,780,000^{\mathrm{d}}$ & -- & -- & -- & -- & -- & -- & -- & -- & -- & -- \\
\hline 2006 & $4,180,000^{\mathrm{d}}$ & -- & -- & -- & -- & -- & -- & -- & -- & -- & -- \\
\hline 2007 & $4,920,000^{\mathrm{d}}$ & -- & -- & -- & -- & -- & -- & -- & -- & -- & -- \\
\hline 2008 & $4,440,000^{\mathrm{d}}$ & -- & -- & -- & -- & -- & -- & -- & -- & -- & -- \\
\hline \multicolumn{12}{|c|}{06610000 Missouri River at Omaha, Nebraska } \\
\hline 1976 & $21,600,000^{\mathrm{d}}$ & -- & -- & -- & -- & 79. & $17,000,000$ & -- & -- & -- & -- \\
\hline 1977 & $14,400,000$ & 73 & 10 & $11,900,000$ & $17,400,000$ & 74 & $10,600,000$ & -- & -- & -- & -- \\
\hline 1978 & $24,600,000$ & 73 & 9 & $20,800,000$ & $29,000,000$ & 54 & $13,400,000$ & 63 & 8 & $11,500,000$ & $15,600,000$ \\
\hline 1979 & $32,300,000$ & 73 & 10 & $26,500,000$ & $38,900,000$ & 58 & $18,600,000$ & 91 & 6 & $16,400,000$ & $21,000,000$ \\
\hline 1980 & $20,500,000$ & 77 & 11 & $16,500,000$ & $25,200,000$ & 54 & $11,100,000$ & 94 & 5 & $10,100,000$ & $12,200,000$ \\
\hline 1981 & $15,000,000$ & 79 & 10 & $12,200,000$ & $18,200,000$ & 54 & $8,160,000$ & -- & -- & -- & -- \\
\hline 1982 & $14,700,000$ & 79 & 11 & $11,900,000$ & $17,900,000$ & 55 & $8,030,000$ & -- & -- & -- & -- \\
\hline 1983 & $35,900,000$ & 78 & 12 & $28,300,000$ & $44,900,000$ & 52 & $18,800,000$ & -- & -- & -- & -- \\
\hline 1984 & $35,600,000$ & 71 & 10 & $29,000,000$ & $43,200,000$ & 55 & $19,700,000$ & -- & -- & -- & -- \\
\hline
\end{tabular}




\begin{tabular}{|c|c|c|c|c|c|c|c|c|c|c|c|}
\hline $\begin{array}{l}\text { Water } \\
\text { Year }\end{array}$ & Load (tons) & $\begin{array}{l}\text { LOADEST } \\
\text { model } r^{2}\end{array}$ & $\begin{array}{c}\text { LOADEST } \\
\text { model } \\
\text { coefficient } \\
\text { of } \\
\text { variation }^{\mathrm{a}} \\
\text { (percent) }\end{array}$ & $\begin{array}{c}\text { Lower } \\
\text { 95-percent } \\
\text { confidence } \\
\text { interval of } \\
\text { LOADEST } \\
\text { load } \\
\text { estimate } \\
\text { (tons) }\end{array}$ & $\begin{array}{c}\text { Upper } \\
\text { 95-percent } \\
\text { confidence } \\
\text { interval of } \\
\text { LOADEST } \\
\text { load estimate } \\
\text { (tons) }\end{array}$ & $\begin{array}{l}\text { Percent of total } \\
\text { suspended- } \\
\text { sediment } \\
\text { load as sand } \\
(>0.0625 \mathrm{~mm})^{\mathrm{b}}\end{array}$ & $\begin{array}{l}\text { Annual } \\
\text { suspended } \\
\text { load (tons) }\end{array}$ & $\begin{array}{l}\text { LOADEST } \\
\text { model } r^{2}\end{array}$ & $\begin{array}{l}\text { LOADEST } \\
\text { model } \\
\text { coefficient } \\
\text { of variation } \\
\text { (percent) }\end{array}$ & $\begin{array}{c}\text { Lower } \\
\text { 95-percent } \\
\text { confidence } \\
\text { interval of } \\
\text { LOADEST } \\
\text { load } \\
\text { estimate } \\
\text { (tons) }\end{array}$ & $\begin{array}{c}\text { Upper } \\
\text { 95-percent } \\
\text { confidence } \\
\text { interval of } \\
\text { LOADEST load } \\
\text { estimate (tons) }\end{array}$ \\
\hline \multicolumn{12}{|c|}{06610000 Missouri River at Omaha, Nebraska—Continued } \\
\hline 1985 & $24,300,000$ & 68 & 9 & $20,300,000$ & $28,900,000$ & 67 & $16,200,000$ & -- & -- & -- & -- \\
\hline 1986 & $28,100,000$ & 67 & 14 & $21,300,000$ & $36,400,000$ & 46 & $12,800,000$ & -- & -- & -- & -- \\
\hline 1987 & $22,600,000$ & 68 & 13 & $17,400,000$ & $29,000,000$ & 62 & $13,900,000$ & -- & -- & -- & -- \\
\hline 1988 & $11,800,000$ & -- & -- & -- & -- & 62 & $7,360,000$ & 86 & 17 & $5,240,000$ & $10,100,000$ \\
\hline 1989 & $8,330,000$ & 59 & 7 & $7,220,000$ & $9,570,000$ & 48 & $4,040,000$ & 75 & 9 & $3,390,000$ & $4,780,000$ \\
\hline 1990 & $9,230,000$ & 59 & 15 & $6,830,000$ & $12,200,000$ & 33 & $3,080,000$ & 75 & 8 & $2,650,000$ & $3,560,000$ \\
\hline 1991 & $11,900,000$ & 59 & 21 & $7,800,000$ & $17,400,000$ & 29 & $3,450,000$ & 75 & 7 & $2,980,000$ & $3,990,000$ \\
\hline 1992 & $10,700,000^{\mathrm{d}}$ & -- & -- & -- & -- & -- & -- & -- & -- & -- & -- \\
\hline 1993 & $28,200,000^{\mathrm{d}}$ & -- & -- & -- & -- & -- & -- & -- & -- & -- & -- \\
\hline 1994 & $16,200,000^{\mathrm{d}}$ & -- & -- & -- & -- & -- & -- & -- & -- & -- & -- \\
\hline 1995 & $17,400,000^{d}$ & -- & -- & -- & -- & -- & -- & -- & -- & -- & -- \\
\hline 1996 & $28,200,000^{\mathrm{d}}$ & -- & -- & -- & -- & -- & -- & -- & -- & -- & -- \\
\hline 1997 & $32,500,000^{\mathrm{d}}$ & -- & -- & -- & -- & -- & -- & -- & -- & -- & -- \\
\hline 1998 & $23,000,000^{\mathrm{d}}$ & -- & -- & -- & -- & -- & -- & -- & -- & -- & -- \\
\hline 1999 & $17,400,000^{\mathrm{d}}$ & -- & -- & -- & -- & -- & -- & -- & -- & -- & -- \\
\hline 2000 & $9,750,000^{\mathrm{d}}$ & -- & -- & -- & -- & -- & -- & -- & -- & -- & -- \\
\hline 2001 & $15,900,000^{\mathrm{d}}$ & -- & -- & -- & -- & -- & -- & -- & -- & -- & -- \\
\hline 2002 & $6,760,000^{\mathrm{d}}$ & -- & -- & -- & -- & -- & -- & -- & -- & -- & -- \\
\hline 2003 & $9,850,000^{\mathrm{d}}$ & -- & -- & -- & -- & -- & -- & -- & -- & -- & -- \\
\hline
\end{tabular}


Table 3. Annual suspended-sediment and suspended-sand loads, and annual LOADEST model characteristics, for selected sediment stations in the lower Missouri River Basin, 1976-2008-Continued

$\left[\mathrm{r}^{2}\right.$, regression model coefficient of determination; --, no data or not applicable; >, greater than; mm, millimeters]

\begin{tabular}{|c|c|c|c|c|c|c|c|c|c|c|c|}
\hline $\begin{array}{c}\text { Water } \\
\text { Year }\end{array}$ & Load (tons) & $\begin{array}{l}\text { LOADEST } \\
\text { model } \mathbf{r}^{2}\end{array}$ & $\begin{array}{l}\text { LOADEST } \\
\text { model } \\
\text { coefficient } \\
\text { of } \\
\text { variation }^{\mathrm{a}} \\
\text { (percent) }^{\text {perce }} \\
\end{array}$ & $\begin{array}{c}\text { Lower } \\
\text { 95-percent } \\
\text { confidence } \\
\text { interval of } \\
\text { LOADEST } \\
\text { load } \\
\text { estimate } \\
\text { (tons) }\end{array}$ & $\begin{array}{c}\text { Upper } \\
\text { 95-percent } \\
\text { confidence } \\
\text { interval of } \\
\text { LOADEST } \\
\text { load estimate } \\
\text { (tons) } \\
\end{array}$ & $\begin{array}{l}\text { Percent of total } \\
\text { suspended- } \\
\text { sediment } \\
\text { load as sand } \\
(>0.0625 \mathrm{~mm})^{\mathrm{b}}\end{array}$ & $\begin{array}{c}\text { Annual } \\
\text { suspended } \\
\text { load (tons) }\end{array}$ & $\begin{array}{c}\text { LOADEST } \\
\text { model } r^{2}\end{array}$ & $\begin{array}{c}\text { LOADEST } \\
\text { model } \\
\text { coefficient } \\
\text { of variation } \\
\text { (percent) }\end{array}$ & $\begin{array}{c}\text { Lower } \\
\text { 95-percent } \\
\text { confidence } \\
\text { interval of } \\
\text { LOADEST } \\
\text { load } \\
\text { estimate } \\
\text { (tons) }\end{array}$ & $\begin{array}{c}\text { Upper } \\
\text { 95-percent } \\
\text { confidence } \\
\text { interval of } \\
\text { LOADEST load } \\
\text { estimate (tons) }\end{array}$ \\
\hline \multicolumn{12}{|c|}{06610000 Missouri River at Omaha, Nebraska—Continued } \\
\hline 2004 & $9,780,000$ & -- & -- & -- & -- & -- & -- & -- & -- & -- & -- \\
\hline 2005 & $8,100,000$ & 81 & 14 & $6,100,000$ & $10,600,000$ & -- & -- & -- & -- & -- & -- \\
\hline 2006 & $\begin{array}{l}5,800,000 \\
{[5,870,000]^{\mathrm{c}}}\end{array}$ & 90 & 12 & $4,530,000$ & $7,310,000$ & -- & -- & -- & -- & -- & -- \\
\hline 2007 & $\begin{array}{r}10,400,000 \\
{[8,010,000]^{\mathrm{c}}}\end{array}$ & 90 & 18 & $7,250,000$ & $14,500,000$ & -- & -- & -- & -- & -- & -- \\
\hline 2008 & $\begin{array}{r}12,400,000 \\
{[10,500,000]^{\mathrm{c}}} \\
\end{array}$ & -- & -- & -- & -- & -- & -- & -- & -- & -- & -- \\
\hline \multicolumn{12}{|c|}{06805500 Platte River at Louisville, Nebraska } \\
\hline 1976 & $2,110,000$ & 88 & 13 & $1,610,000$ & $2,720,000$ & -- & -- & -- & -- & -- & -- \\
\hline 1977 & $4,280,000$ & 89 & 16 & $3,070,000$ & $5,820,000$ & -- & -- & -- & -- & -- & -- \\
\hline 1978 & $15,100,000$ & 85 & 32 & $7,740,000$ & $26,500,000$ & -- & -- & -- & -- & -- & -- \\
\hline 1979 & $7,080,000$ & 85 & 19 & $4,820,000$ & $10,000,000$ & -- & -- & -- & -- & -- & -- \\
\hline 1980 & $7,960,000$ & 76 & 20 & $5,250,000$ & $11,600,000$ & & -- & -- & -- & -- & -- \\
\hline 1981 & $2,370,000$ & 82 & 16 & $1,710,000$ & $3,200,000$ & -- & -- & -- & -- & -- & -- \\
\hline 1982 & $15,800,000$ & 84 & 32 & $8,170,000$ & $27,700,000$ & -- & -- & -- & -- & -- & -- \\
\hline 1983 & $31,500,000$ & 90 & 31 & $16,500,000$ & $54,800,000$ & -- & -- & -- & -- & -- & -- \\
\hline 1984 & $57,400,000$ & 89 & 42 & $23,900,000$ & $117,000,000$ & -- & -- & -- & -- & -- & -- \\
\hline 1985 & $10,600,000$ & 83 & 19 & $7,170,000$ & $15,100,000$ & -- & -- & -- & -- & -- & -- \\
\hline 1986 & $13,000,000$ & 87 & 22 & $8,360,000$ & $19,300,000$ & -- & -- & -- & -- & -- & -- \\
\hline 1987 & $20,300,000$ & 87 & 39 & $9,060,000$ & $39,600,000$ & -- & -- & -- & -- & -- & -- \\
\hline
\end{tabular}




\begin{tabular}{|c|c|c|c|c|c|c|c|c|c|c|c|}
\hline $\begin{array}{l}\text { Water } \\
\text { Year }\end{array}$ & Load (tons) & $\begin{array}{l}\text { LOADEST } \\
\text { model } r^{2}\end{array}$ & $\begin{array}{l}\text { LOADEST } \\
\text { model } \\
\text { coefficient } \\
\text { of } \\
\text { variation } \\
\text { (percent) } \\
\end{array}$ & $\begin{array}{c}\text { Lower } \\
\text { 95-percent } \\
\text { confidence } \\
\text { interval of } \\
\text { LOADEST } \\
\text { load } \\
\text { estimate } \\
\text { (tons) }\end{array}$ & $\begin{array}{c}\text { Upper } \\
\text { 95-percent } \\
\text { confidence } \\
\text { interval of } \\
\text { LOADEST } \\
\text { load estimate } \\
\text { (tons) } \\
\end{array}$ & $\begin{array}{l}\text { Percent of total } \\
\text { suspended- } \\
\text { sediment } \\
\text { load as sand } \\
(>0.0625 \mathrm{~mm})^{\mathrm{b}}\end{array}$ & $\begin{array}{c}\text { Annual } \\
\text { suspended } \\
\text { load (tons) }\end{array}$ & $\begin{array}{l}\text { LOADEST } \\
\text { model } r^{2}\end{array}$ & $\begin{array}{l}\text { LOADEST } \\
\text { model } \\
\text { coefficient } \\
\text { of variation } \\
\text { (percent) }\end{array}$ & $\begin{array}{c}\text { Lower } \\
\text { 95-percent } \\
\text { confidence } \\
\text { interval of } \\
\text { LOADEST } \\
\text { load } \\
\text { estimate } \\
\text { (tons) }\end{array}$ & $\begin{array}{c}\text { Upper } \\
\text { 95-percent } \\
\text { confidence } \\
\text { interval of } \\
\text { LOADEST load } \\
\text { estimate (tons) }\end{array}$ \\
\hline \multicolumn{12}{|c|}{06805500 Platte River at Louisville, Nebraska-Continued } \\
\hline 1988 & $2,590,000$ & -- & -- & -- & -- & -- & -- & -- & -- & -- & -- \\
\hline 1989 & $3,560,000$ & 86 & 42 & $1,500,000$ & $7,190,000$ & -- & -- & -- & -- & -- & -- \\
\hline 1990 & $12,200,000$ & -- & -- & -- & -- & -- & -- & -- & -- & -- & -- \\
\hline 1991 & $15,000,000$ & 82 & 44 & $5,960,000$ & $31,500,000$ & -- & -- & -- & -- & -- & -- \\
\hline 1992 & $5,280,000$ & 83 & 14 & $3,940,000$ & $6,930,000$ & -- & -- & -- & -- & -- & -- \\
\hline 1993 & $81,100,000$ & 82 & 39 & $36,400,000$ & $157,000,000$ & -- & -- & -- & -- & -- & -- \\
\hline 1994 & $6,840,000$ & 84 & 20 & $4,520,000$ & $9,940,000$ & -- & -- & -- & -- & -- & -- \\
\hline 1995 & $20,200,000$ & 80 & 36 & $9,580,000$ & $37,600,000$ & -- & -- & -- & -- & -- & -- \\
\hline 1996 & $15,200,000$ & 80 & 17 & $10,700,000$ & $20,900,000$ & -- & -- & -- & -- & -- & -- \\
\hline 1997 & $9,820,000$ & 79 & 17 & $6,940,000$ & $13,500,000$ & -- & -- & -- & -- & -- & -- \\
\hline 1998 & $19,800,000$ & 80 & 17 & $13,900,000$ & $27,300,000$ & -- & -- & -- & -- & -- & -- \\
\hline 1999 & $25,700,000$ & 81 & 20 & $17,100,000$ & $37,100,000$ & -- & -- & -- & -- & -- & -- \\
\hline 2000 & $4,850,000$ & 86 & 12 & $3,780,000$ & $6,140,000$ & -- & -- & -- & -- & -- & -- \\
\hline 2001 & $9,690,000$ & 81 & 24 & $5,870,000$ & $15,100,000$ & -- & -- & -- & -- & -- & -- \\
\hline 2002 & $2,810,000$ & 78 & 18 & $1,950,000$ & $3,920,000$ & -- & -- & -- & -- & -- & -- \\
\hline 2003 & $3,130,000$ & 73 & 24 & $1,930,000$ & $4,800,000$ & -- & -- & -- & -- & -- & -- \\
\hline 2004 & $4,480,000$ & 82 & 31 & $2,380,000$ & $7,690,000$ & -- & -- & -- & -- & -- & -- \\
\hline 2005 & $7,300,000$ & 88 & 31 & $3,880,000$ & $12,600,000$ & -- & -- & -- & -- & -- & -- \\
\hline 2006 & $2,330,000$ & 84 & 11 & $1,850,000$ & $2,890,000$ & -- & -- & -- & -- & -- & -- \\
\hline 2007 & $10,900,000$ & 87 & 16 & $7,810,000$ & $14,700,000$ & -- & -- & -- & -- & -- & -- \\
\hline 2008 & $18,200,000$ & 87 & 21 & $11,900,000$ & $26,700,000$ & -- & -- & -- & -- & -- & -- \\
\hline
\end{tabular}


Table 3. Annual suspended-sediment and suspended-sand loads, and annual LOADEST model characteristics, for selected sediment stations in the lower Missouri River Basin, 1976-2008-Continued

$\left[\mathrm{r}^{2}\right.$, regression model coefficient of determination; --, no data or not applicable; >, greater than; mm, millimeters]

\begin{tabular}{|c|c|c|c|c|c|c|c|c|c|c|c|}
\hline $\begin{array}{l}\text { Water } \\
\text { Year }\end{array}$ & Load (tons) & $\begin{array}{l}\text { LOADEST } \\
\text { model } r^{2}\end{array}$ & $\begin{array}{l}\text { LOADEST } \\
\text { model } \\
\text { coefficient } \\
\text { of } \\
\text { variation }^{a} \\
\text { (percent) }\end{array}$ & $\begin{array}{c}\text { Lower } \\
\text { 95-percent } \\
\text { confidence } \\
\text { interval of } \\
\text { LOADEST } \\
\text { load } \\
\text { estimate } \\
\text { (tons) }\end{array}$ & $\begin{array}{c}\text { Upper } \\
\text { 95-percent } \\
\text { confidence } \\
\text { interval of } \\
\text { LOADEST } \\
\text { load estimate } \\
\text { (tons) }\end{array}$ & $\begin{array}{l}\text { Percent of total } \\
\text { suspended- } \\
\text { sediment } \\
\text { load as sand } \\
(>0.0625 \mathrm{~mm})^{\mathrm{b}}\end{array}$ & $\begin{array}{c}\text { Annual } \\
\text { suspended } \\
\text { load (tons) }\end{array}$ & $\begin{array}{l}\text { LOADEST } \\
\text { model } r^{2}\end{array}$ & $\begin{array}{l}\text { LOADEST } \\
\text { model } \\
\text { coefficient } \\
\text { of variation } \\
\text { (percent) }\end{array}$ & $\begin{array}{c}\text { Lower } \\
\text { 95-percent } \\
\text { confidence } \\
\text { interval of } \\
\text { LOADEST } \\
\text { load } \\
\text { estimate } \\
\text { (tons) }\end{array}$ & $\begin{array}{c}\text { Upper } \\
\text { 95-percent } \\
\text { confidence } \\
\text { interval of } \\
\text { LOADEST load } \\
\text { estimate (tons) }\end{array}$ \\
\hline \multicolumn{12}{|c|}{06807000 Missouri River at Nebraska City, Nebraska } \\
\hline 1976 & $25,564,030^{d}$ & -- & -- & -- & -- & -- & -- & -- & -- & -- & -- \\
\hline 1977 & $24,000,000^{f}$ & 40 & 10 & $19,800,000$ & $28,800,000$ & 73 & $17,500,000^{\mathrm{f}}$ & 45 & 13 & $13,500,000$ & $22,200,000$ \\
\hline 1978 & $33,200,000$ & 56 & 12 & $26,200,000$ & $41,400,000$ & 63 & $21,000,000^{\mathrm{f}}$ & 45 & 9 & $17,700,000$ & $24,800,000$ \\
\hline 1979 & $39,200,000$ & 48 & 14 & $29,800,000$ & $50,600,000$ & 66 & $25,700,000$ & -- & -- & -- & -- \\
\hline 1980 & $19,600,000$ & 78 & 14 & $14,800,000$ & $25,500,000$ & 78 & $15,200,000$ & 79 & 9 & $12,600,000$ & $18,200,000$ \\
\hline 1981 & $16,400,000$ & -- & -- & -- & -- & 51 & $8,380,000$ & 78 & 9 & $6,990,000$ & $9,960,000$ \\
\hline 1982 & $26,200,000$ & 69 & 12 & $20,400,000$ & $33,000,000$ & 47 & $12,200,000$ & 79 & 8 & $10,400,000$ & $14,300,000$ \\
\hline 1983 & $70,300,000$ & -- & -- & -- & -- & 40 & $27,800,000$ & 82 & 9 & $23,100,000$ & $33,200,000$ \\
\hline 1984 & $88,000,000$ & 65 & 21 & $56,800,000$ & $130,000,000$ & 38 & $33,400,000$ & 77 & 14 & $24,900,000$ & $43,800,000$ \\
\hline 1985 & $43,600,000$ & 84 & 17 & $31,000,000$ & $59,700,000$ & 48 & $21,000,000$ & 82 & 14 & $15,900,000$ & $27,200,000$ \\
\hline 1986 & $38,400,000$ & -- & -- & -- & -- & 49 & $18,800,000$ & 75 & 11 & $15,100,000$ & $23,100,000$ \\
\hline 1987 & $50,300,000$ & 77 & 20 & $33,100,000$ & $73,200,000$ & 58 & $21,200,000$ & 61 & 46 & $11,200,000$ & $62,400,000$ \\
\hline 1988 & $15,200,000$ & 64 & 10 & $12,500,000$ & $18,200,000$ & 62 & $9,430,000$ & 85 & 13 & $7,260,000$ & $12,000,000$ \\
\hline 1989 & $12,200,000$ & 51 & 10 & $9,930,000$ & $14,900,000$ & 54 & $6,630,000$ & 69 & 16 & $4,770,000$ & $8,970,000$ \\
\hline 1990 & $16,300,000$ & 51 & 34 & $8,030,000$ & $29,600,000$ & 33 & $5,710,000$ & 69 & 13 & $4,150,000$ & $6,950,000$ \\
\hline 1991 & $19,200,000$ & 51 & 27 & $11,100,000$ & $31,000,000$ & 30 & $6,960,000$ & 69 & 14 & $4,320,000$ & $7,400,000$ \\
\hline 1992 & $18,900,000^{\mathrm{d}}$ & -- & -- & -- & -- & -- & -- & -- & -- & -- & -- \\
\hline 1993 & $46,100,000^{\mathrm{d}}$ & -- & -- & -- & -- & -- & -- & -- & -- & -- & -- \\
\hline
\end{tabular}




\begin{tabular}{|c|c|c|c|c|c|c|c|c|c|c|c|}
\hline $\begin{array}{l}\text { Water } \\
\text { Year }\end{array}$ & Load (tons) & $\begin{array}{l}\text { LOADEST } \\
\text { model } r^{2}\end{array}$ & $\begin{array}{l}\text { LOADEST } \\
\text { model } \\
\text { coefficient } \\
\quad \text { of } \\
\text { variation } \\
\text { (percent) }\end{array}$ & $\begin{array}{c}\text { Lower } \\
\text { 95-percent } \\
\text { confidence } \\
\text { interval of } \\
\text { LOADEST } \\
\text { load } \\
\text { estimate } \\
\text { (tons) }\end{array}$ & $\begin{array}{c}\text { Upper } \\
\text { 95-percent } \\
\text { confidence } \\
\text { interval of } \\
\text { LOADEST } \\
\text { load estimate } \\
\text { (tons) }\end{array}$ & $\begin{array}{l}\text { Percent of total } \\
\text { suspended- } \\
\text { sediment } \\
\text { load as sand } \\
(>0.0625 \mathrm{~mm})^{\mathrm{b}}\end{array}$ & $\begin{array}{c}\text { Annual } \\
\text { suspended } \\
\text { load (tons) }\end{array}$ & $\begin{array}{l}\text { LOADEST } \\
\text { model } r^{2}\end{array}$ & $\begin{array}{l}\text { LOADEST } \\
\text { model } \\
\text { coefficient } \\
\text { of variation } \\
\text { (percent) }\end{array}$ & $\begin{array}{c}\text { Lower } \\
\text { 95-percent } \\
\text { confidence } \\
\text { interval of } \\
\text { LOADEST } \\
\text { load } \\
\text { estimate } \\
\text { (tons) }\end{array}$ & $\begin{array}{c}\text { Upper } \\
\text { 95-percent } \\
\text { confidence } \\
\text { interval of } \\
\text { LOADEST load } \\
\text { estimate (tons) }\end{array}$ \\
\hline \multicolumn{12}{|c|}{06807000 Missouri River at Nebraska City, Nebraska_Continued } \\
\hline 1994 & $26,200,000^{d}$ & -- & -- & -- & -- & -- & -- & -- & -- & -- & -- \\
\hline 1995 & $29,100,000^{\mathrm{d}}$ & -- & -- & -- & -- & -- & -- & -- & -- & -- & -- \\
\hline 1996 & $51,400,000^{\mathrm{d}}$ & -- & -- & -- & -- & -- & -- & -- & -- & -- & -- \\
\hline 1997 & $41,200,000^{\mathrm{d}}$ & -- & -- & -- & -- & -- & -- & -- & -- & -- & -- \\
\hline 1998 & $38,700,000^{\mathrm{d}}$ & -- & -- & -- & -- & -- & -- & -- & -- & -- & -- \\
\hline 1999 & $31,500,000^{\mathrm{d}}$ & -- & -- & -- & -- & -- & -- & -- & -- & -- & -- \\
\hline 2000 & $14,200,000^{\mathrm{d}}$ & -- & -- & -- & -- & -- & -- & -- & -- & -- & -- \\
\hline 2001 & $23,000,000^{\mathrm{d}}$ & -- & -- & -- & -- & -- & -- & -- & -- & -- & -- \\
\hline 2002 & $11,200,000^{\mathrm{d}}$ & -- & -- & -- & -- & -- & -- & -- & -- & -- & -- \\
\hline 2003 & $14,700,000^{\mathrm{d}}$ & -- & -- & -- & -- & -- & -- & -- & -- & -- & -- \\
\hline 2004 & $16,300,000^{\mathrm{d}}$ & -- & -- & -- & -- & -- & -- & -- & -- & -- & -- \\
\hline 2005 & $14,300,000^{\mathrm{d}}$ & -- & -- & -- & -- & -- & -- & -- & -- & -- & -- \\
\hline 2006 & $\begin{array}{r}9,330,000^{\mathrm{d}} \\
{[7,780,000]^{\mathrm{c}}}\end{array}$ & -- & -- & -- & -- & -- & -- & -- & -- & -- & -- \\
\hline 2007 & $\begin{array}{r}22,100,000^{\mathrm{d}} \\
{[17,200,000]^{\mathrm{c}}}\end{array}$ & -- & -- & -- & -- & -- & -- & -- & -- & -- & -- \\
\hline 2008 & $\begin{array}{r}33,800,000^{\mathrm{d}} \\
{[18,000,000]^{\mathrm{c}}}\end{array}$ & -- & -- & -- & -- & -- & -- & -- & -- & -- & -- \\
\hline \multicolumn{12}{|c|}{06810000 Nishnabotna River at Hamburg, lowa } \\
\hline 1982 & $6,190,000$ & 94 & 39 & $2,750,000$ & $12,100,000$ & -- & -- & -- & -- & -- & -- \\
\hline 1984 & $14,600,000$ & 94 & 42 & $6,090,000$ & $29,800,000$ & -- & -- & -- & -- & -- & -- \\
\hline 1985 & 551,000 & 92 & 21 & 357,000 & 812,000 & -- & -- & -- & -- & -- & -- \\
\hline 1986 & $4,930,000$ & 94 & 35 & $2,390,000$ & $9,070,000$ & -- & -- & -- & -- & -- & -- \\
\hline
\end{tabular}


Table 3. Annual suspended-sediment and suspended-sand loads, and annual LOADEST model characteristics, for selected sediment stations in the lower Missouri River Basin, 1976-2008-Continued

$\left[\mathrm{r}^{2}\right.$, regression model coefficient of determination; --, no data or not applicable; >, greater than; mm, millimeters]

\begin{tabular}{|c|c|c|c|c|c|c|c|c|c|c|c|}
\hline $\begin{array}{l}\text { Water } \\
\text { Year }\end{array}$ & Load (tons) & $\begin{array}{l}\text { LOADEST } \\
\text { model } r^{2}\end{array}$ & $\begin{array}{l}\text { LOADEST } \\
\text { model } \\
\text { coefficient } \\
\text { of } \\
\text { variation } \\
\text { (percent) }\end{array}$ & $\begin{array}{c}\text { Lower } \\
\text { 95-percent } \\
\text { confidence } \\
\text { interval of } \\
\text { LOADEST } \\
\text { load } \\
\text { estimate } \\
\text { (tons) }\end{array}$ & $\begin{array}{c}\text { Upper } \\
\text { 95-percent } \\
\text { confidence } \\
\text { interval of } \\
\text { LOADEST } \\
\text { load estimate } \\
\text { (tons) }\end{array}$ & $\begin{array}{l}\text { Percent of total } \\
\text { suspended- } \\
\text { sediment } \\
\text { load as sand } \\
(>0.0625 \mathrm{~mm})^{\mathrm{b}}\end{array}$ & $\begin{array}{c}\text { Annual } \\
\text { suspended } \\
\text { load (tons) }\end{array}$ & $\begin{array}{l}\text { LOADEST } \\
\text { model } r^{2}\end{array}$ & $\begin{array}{l}\text { LOADEST } \\
\text { model } \\
\text { coefficient } \\
\text { of variation } \\
\text { (percent) }\end{array}$ & $\begin{array}{c}\text { Lower } \\
\text { 95-percent } \\
\text { confidence } \\
\text { interval of } \\
\text { LOADEST } \\
\text { load } \\
\text { estimate } \\
\text { (tons) }\end{array}$ & $\begin{array}{c}\text { Upper } \\
\text { 95-percent } \\
\text { confidence } \\
\text { interval of } \\
\text { LOADEST load } \\
\text { estimate (tons) }\end{array}$ \\
\hline \multicolumn{12}{|c|}{06810000 Nishnabotna River at Hamburg, lowa-Continued } \\
\hline 1987 & $18,600,000$ & 94 & 58 & $5,630,000$ & $46,200,000$ & -- & -- & -- & -- & -- & -- \\
\hline 1988 & 267,000 & 92 & 23 & 168,000 & 404,000 & -- & -- & -- & -- & -- & -- \\
\hline 1989 & $4,450,000$ & 93 & 73 & $1,000,000$ & $12,900,000$ & -- & -- & -- & -- & -- & -- \\
\hline 1990 & $7,860,000$ & 90 & 77 & $1,650,000$ & $23,600,000$ & -- & -- & -- & -- & -- & -- \\
\hline 1991 & $5,080,000$ & 94 & 53 & $1,680,000$ & $11,900,000$ & -- & -- & -- & -- & -- & -- \\
\hline 1992 & $1,060,000$ & 94 & 28 & 598,000 & $1,730,000$ & -- & -- & -- & -- & -- & -- \\
\hline 1993 & $26,900,000$ & 94 & 42 & $11,300,000$ & $54,400,000$ & -- & -- & -- & -- & -- & -- \\
\hline-- & -- & -- & -- & -- & -- & -- & -- & -- & -- & -- & -- \\
\hline 2004 & $3,840,000$ & 94 & 37 & $1,770,000$ & $7,300,000$ & -- & -- & -- & -- & -- & -- \\
\hline 2005 & $2,050,000$ & 94 & 32 & $1,060,000$ & $3,590,000$ & -- & -- & -- & -- & -- & -- \\
\hline 2006 & 192,000 & 94 & 23 & 121,000 & 291,000 & -- & -- & -- & -- & -- & -- \\
\hline 2007 & $4,920,000$ & 94 & 28 & $2,760,000$ & $8,130,000$ & -- & -- & -- & -- & -- & -- \\
\hline 2008 & $8,300,000$ & 91 & 26 & $4,880,000$ & $13,200,000$ & -- & -- & -- & -- & -- & -- \\
\hline
\end{tabular}

06817000 Nodaway River at Clarinda, lowa

\begin{tabular}{llll}
\hline 1976 & $1,340,000^{\mathrm{d}}$ & -- & - \\
1977 & $2,430,000^{\mathrm{d}}$ & -- & - \\
1978 & $4,310,000^{\mathrm{d}}$ & -- & - \\
1979 & $2,470,000^{\mathrm{d}}$ & -- & -
\end{tabular}




\begin{tabular}{|c|c|c|c|c|c|c|c|c|c|c|c|}
\hline $\begin{array}{l}\text { Water } \\
\text { Year }\end{array}$ & Load (tons) & $\begin{array}{l}\text { LOADEST } \\
\text { model } r^{2}\end{array}$ & $\begin{array}{l}\text { LOADEST } \\
\text { model } \\
\text { coefficient } \\
\text { of } \\
\text { variation } \\
\text { (percent) }\end{array}$ & $\begin{array}{c}\text { Lower } \\
\text { 95-percent } \\
\text { confidence } \\
\text { interval of } \\
\text { LOADEST } \\
\text { load } \\
\text { estimate } \\
\text { (tons) }\end{array}$ & $\begin{array}{c}\text { Upper } \\
\text { 95-percent } \\
\text { confidence } \\
\text { interval of } \\
\text { LOADEST } \\
\text { load estimate } \\
\text { (tons) }\end{array}$ & $\begin{array}{l}\text { Percent of total } \\
\text { suspended- } \\
\text { sediment } \\
\text { load as sand } \\
(>0.0625 \mathrm{~mm})^{\mathrm{b}}\end{array}$ & $\begin{array}{c}\text { Annual } \\
\text { suspended } \\
\text { load (tons) }\end{array}$ & $\begin{array}{l}\text { LOADEST } \\
\text { model } r^{2}\end{array}$ & $\begin{array}{l}\text { LOADEST } \\
\text { model } \\
\text { coefficient } \\
\text { of variation } \\
\text { (percent) }\end{array}$ & $\begin{array}{c}\text { Lower } \\
\text { 95-percent } \\
\text { confidence } \\
\text { interval of } \\
\text { LOADEST } \\
\text { load } \\
\text { estimate } \\
\text { (tons) }\end{array}$ & $\begin{array}{c}\text { Upper } \\
\text { 95-percent } \\
\text { confidence } \\
\text { interval of } \\
\text { LOADEST load } \\
\text { estimate (tons) }\end{array}$ \\
\hline
\end{tabular}

06817000 Nodaway River at Clarinda, lowa-Continued

\begin{tabular}{|c|c|c|c|c|c|c|c|c|c|c|c|}
\hline 1980 & $1,140,000^{\mathrm{d}}$ & -- & -- & -- & -- & -- & -- & -- & -- & -- & -- \\
\hline 1981 & $203,000^{d}$ & -- & -- & -- & -- & -- & -- & -- & -- & -- & -- \\
\hline 1982 & $5,850,000^{\mathrm{d}}$ & -- & -- & -- & -- & -- & -- & -- & -- & -- & -- \\
\hline 1983 & $1,370,000^{\mathrm{d}}$ & -- & -- & -- & -- & -- & -- & -- & -- & -- & -- \\
\hline 1984 & $2,770,000^{\mathrm{d}}$ & -- & -- & -- & -- & -- & -- & -- & -- & -- & -- \\
\hline 1985 & $453,000^{\mathrm{d}}$ & -- & -- & -- & -- & -- & -- & -- & -- & -- & -- \\
\hline 1986 & $3,530,000^{\mathrm{d}}$ & -- & -- & -- & -- & -- & -- & -- & -- & -- & -- \\
\hline 1987 & $3,270,000^{\mathrm{d}}$ & -- & -- & -- & -- & -- & -- & -- & -- & -- & -- \\
\hline 1988 & $15,900^{\mathrm{d}}$ & -- & -- & -- & -- & -- & -- & -- & -- & -- & -- \\
\hline 1989 & $2,680,000^{\mathrm{d}}$ & -- & -- & -- & -- & -- & -- & -- & -- & -- & -- \\
\hline 1990 & $1,610,000^{\mathrm{d}}$ & -- & -- & -- & -- & -- & -- & -- & -- & -- & -- \\
\hline 1991 & $4,090,000^{\mathrm{d}}$ & -- & -- & -- & -- & -- & -- & -- & -- & -- & -- \\
\hline 1992 & $1,270,000^{\mathrm{d}}$ & -- & -- & -- & -- & -- & -- & -- & -- & -- & -- \\
\hline
\end{tabular}

06818000 Missouri River at St. Joseph, Missouri

\begin{tabular}{|c|c|c|c|c|c|c|c|c|c|c|c|}
\hline 1976 & $(33,300,000)^{\mathrm{e}}$ & -- & -- & -- & -- & 50 & $(16,600,000)^{\mathrm{e}}$ & -- & & & \\
\hline 1977 & $(21,300,000)^{\mathrm{e}}$ & -- & -- & -- & -- & 59 & $(12,500,000)^{\mathrm{e}}$ & -- & -- & -- & -- \\
\hline 1978 & $(37,400,000)^{\mathrm{e}}$ & -- & -- & -- & -- & 51 & $(19,100,000)^{\mathrm{e}}$ & -- & -- & -- & -- \\
\hline 1979 & $(37,300,000)^{\mathrm{e}}$ & -- & -- & -- & -- & 46 & $(17,000,000)^{\mathrm{e}}$ & -- & -- & -- & -- \\
\hline 1980 & $(36,700,000)^{\mathrm{e}}$ & -- & -- & -- & -- & 30 & $(10,900,000)^{\mathrm{e}}$ & -- & -- & -- & -- \\
\hline 1981 & $(22,900,000)^{\mathrm{e}}$ & -- & -- & -- & -- & 36 & $(8,920,000)^{\mathrm{e}}$ & -- & -- & -- & -- \\
\hline
\end{tabular}


Table 3. Annual suspended-sediment and suspended-sand loads, and annual LOADEST model characteristics, for selected sediment stations in the lower Missouri River Basin, 1976-2008-Continued

$\left[\mathrm{r}^{2}\right.$, regression model coefficient of determination; --, no data or not applicable; >, greater than; mm, millimeters]

\begin{tabular}{|c|c|c|c|c|c|c|c|c|c|c|c|}
\hline $\begin{array}{l}\text { Water } \\
\text { Year }\end{array}$ & Load (tons) & $\begin{array}{l}\text { LOADEST } \\
\text { model } r^{2}\end{array}$ & $\begin{array}{l}\text { LOADEST } \\
\text { model } \\
\text { coefficient } \\
\text { of } \\
\text { variation }^{\text {a }} \\
\text { (percent) }\end{array}$ & $\begin{array}{c}\text { Lower } \\
\text { 95-percent } \\
\text { confidence } \\
\text { interval of } \\
\text { LOADEST } \\
\text { load } \\
\text { estimate } \\
\text { (tons) }\end{array}$ & $\begin{array}{c}\text { Upper } \\
\text { 95-percent } \\
\text { confidence } \\
\text { interval of } \\
\text { LOADEST } \\
\text { load estimate } \\
\text { (tons) }\end{array}$ & $\begin{array}{l}\text { Percent of total } \\
\text { suspended- } \\
\text { sediment } \\
\text { load as sand } \\
(>0.0625 \mathrm{~mm})^{\mathrm{b}}\end{array}$ & $\begin{array}{c}\text { Annual } \\
\text { suspended } \\
\text { load (tons) }\end{array}$ & $\begin{array}{l}\text { LOADEST } \\
\text { model } r^{2}\end{array}$ & $\begin{array}{l}\text { LOADEST } \\
\text { model } \\
\text { coefficient } \\
\text { of variation } \\
\text { (percent) }\end{array}$ & $\begin{array}{c}\text { Lower } \\
\text { 95-percent } \\
\text { confidence } \\
\text { interval of } \\
\text { LOADEST } \\
\text { load } \\
\text { estimate } \\
\text { (tons) }\end{array}$ & $\begin{array}{c}\text { Upper } \\
\text { 95-percent } \\
\text { confidence } \\
\text { interval of } \\
\text { LOADEST load } \\
\text { estimate (tons) }\end{array}$ \\
\hline \multicolumn{12}{|c|}{06818000 Missouri River at St. Joseph, Missouri-Continued } \\
\hline 1982 & $54,400,000$ & 79 & 17 & $38,800,000$ & $74,200,000$ & 50 & $27,200,000^{\mathrm{f}}$ & 43 & 22 & $17,300,000$ & $40,600,000$ \\
\hline 1983 & $122,000,000$ & -- & -- & -- & -- & 37 & $45,200,000$ & 54 & 50 & $16,100,000$ & $102,000,000$ \\
\hline 1984 & $115,000,000^{\mathrm{f}}$ & 48 & 57 & $35,200,000$ & $281,000,000$ & 24 & $28,100,000^{\mathrm{f}}$ & 12 & 84 & $5,140,000$ & $89,900,000$ \\
\hline 1985 & $35,100,000$ & -- & -- & -- & -- & 40 & $14,300,000^{\mathrm{f}}$ & 42 & 30 & $7,770,000$ & $24,200,000$ \\
\hline 1986 & $60,000,000^{\mathrm{f}}$ & 39 & 26 & $34,900,000$ & $96,500,000$ & 34 & $20,600,000$ & -- & -- & -- & -- \\
\hline 1987 & $74,600,000$ & 51 & 24 & $45,900,000$ & $115,000,000$ & 34 & $25,500,000$ & -- & -- & -- & -- \\
\hline 1988 & $19,400,000$ & 55 & 11 & $15,500,000$ & $24,000,000$ & 57 & $11,100,000$ & -- & -- & -- & -- \\
\hline 1989 & $23,100,000$ & -- & -- & -- & -- & 42 & $9,680,000$ & 58 & 13 & $7,460,000$ & $12,400,000$ \\
\hline 1990 & $33,000,000$ & 78 & 22 & $20,900,000$ & $49,800,000$ & 22 & $7,350,000$ & 73 & 9 & $6,160,000$ & $8,700,000$ \\
\hline 1991 & $28,900,000$ & 85 & 18 & $19,900,000$ & $40,700,000$ & 21 & $6,000,000$ & 79 & 6 & $5,300,000$ & $6,770,000$ \\
\hline 1992 & $29,500,000$ & 78 & 14 & $22,300,000$ & $38,400,000$ & 27 & $7,930,000$ & 82 & 7 & $6,910,000$ & $9,040,000$ \\
\hline 1993 & $136,000,000$ & 82 & 34 & $67,500,000$ & $246,000,000$ & 16 & $21,500,000$ & 82 & 17 & $15,100,000$ & $29,700,000$ \\
\hline 1994 & $26,900,000$ & 88 & 10 & $21,800,000$ & $32,700,000$ & 33 & $8,880,000$ & 92 & 5 & $7,980,000$ & $9,850,000$ \\
\hline 1995 & $31,900,000$ & 84 & 13 & $24,400,000$ & $41,100,000$ & 33 & $10,600,000$ & -- & -- & -- & -- \\
\hline 1996 & $38,800,000$ & 87 & 9 & $32,700,000$ & $45,600,000$ & 38 & $14,800,000$ & 91 & 6 & $13,100,000$ & $16,700,000$ \\
\hline 1997 & $60,600,000$ & 83 & 11 & $48,700,000$ & $74,600,000$ & 38 & $22,800,000$ & 89 & 7 & $19,700,000$ & $26,200,000$ \\
\hline 1998 & $47,700,000$ & 86 & 11 & $38,100,000$ & $58,900,000$ & 31 & $14,700,000$ & 92 & 7 & $12,800,000$ & $16,700,000$ \\
\hline 1999 & $61,500,000$ & 87 & 14 & $46,500,000$ & $79,900,000$ & 22 & $13,300,000$ & -- & -- & -- & -- \\
\hline
\end{tabular}




\begin{tabular}{|c|c|c|c|c|c|c|c|c|c|c|c|}
\hline $\begin{array}{c}\text { Water } \\
\text { Year }\end{array}$ & Load (tons) & $\begin{array}{l}\text { LOADEST } \\
\text { model } r^{2}\end{array}$ & $\begin{array}{l}\text { LOADEST } \\
\text { model } \\
\text { coefficient } \\
\text { of } \\
\text { variation }^{\mathrm{a}} \\
\text { (percent) }^{\text {percen }}\end{array}$ & $\begin{array}{c}\text { Lower } \\
\text { 95-percent } \\
\text { confidence } \\
\text { interval of } \\
\text { LOADEST } \\
\text { load } \\
\text { estimate } \\
\text { (tons) } \\
\end{array}$ & $\begin{array}{c}\text { Upper } \\
\text { 95-percent } \\
\text { confidence } \\
\text { interval of } \\
\text { LOADEST } \\
\text { load estimate } \\
\text { (tons) } \\
\end{array}$ & $\begin{array}{l}\text { Percent of total } \\
\text { suspended- } \\
\text { sediment } \\
\text { load as sand } \\
(>0.0625 \mathrm{~mm})^{\mathrm{b}}\end{array}$ & $\begin{array}{c}\text { Annual } \\
\text { suspended } \\
\text { load (tons) }\end{array}$ & $\begin{array}{c}\text { LOADEST } \\
\text { model } r^{2}\end{array}$ & $\begin{array}{l}\text { LOADEST } \\
\text { model } \\
\text { coefficient } \\
\text { of variation } \\
\text { (percent) }\end{array}$ & $\begin{array}{c}\text { Lower } \\
\text { 95-percent } \\
\text { confidence } \\
\text { interval of } \\
\text { LOADEST } \\
\text { load } \\
\text { estimate } \\
\text { (tons) }\end{array}$ & $\begin{array}{c}\text { Upper } \\
\text { 95-percent } \\
\text { confidence } \\
\text { interval of } \\
\text { LOADEST load } \\
\text { estimate (tons) }\end{array}$ \\
\hline \multicolumn{12}{|c|}{06818000 Missouri River at St. Joseph, Missouri-Continued } \\
\hline 2000 & $15,600,000$ & 91 & 10 & $12,900,000$ & $18,800,000$ & 39 & $6,120,000$ & 89 & 11 & $4,920,000$ & $7,520,000$ \\
\hline 2001 & $37,400,000$ & 76 & 20 & $24,900,000$ & $53,900,000$ & 20 & $7,400,000$ & 74 & 11 & $5,920,000$ & $9,130,000$ \\
\hline 2002 & $13,600,000$ & 77 & 12 & $10,700,000$ & $17,200,000$ & 28 & $3,790,000$ & 79 & 9 & $3,190,000$ & $4,470,000$ \\
\hline 2003 & $20,700,000$ & -- & -- & -- & -- & 19 & $3,910,000$ & 83 & 5 & $3,520,000$ & $4,330,000$ \\
\hline 2004 & $26,200,000$ & -- & -- & -- & -- & 18 & $4,840,000$ & -- & -- & -- & -- \\
\hline 2005 & $16,100,000$ & 85 & 10 & $13,300,000$ & $19,400,000$ & 18 & $2,860,000$ & -- & -- & -- & -- \\
\hline 2006 & $\begin{array}{r}11,500,000 \\
{[9,630,000]^{\mathrm{c}}}\end{array}$ & 75 & 7 & $9,890,000$ & $13,200,000$ & -- & -- & -- & -- & -- & -- \\
\hline 2007 & $\begin{array}{r}29,200,000 \\
{[40,300,000]^{\mathrm{c}}}\end{array}$ & 93 & 9 & $24,300,000$ & $34,700,000$ & -- & -- & -- & -- & -- & -- \\
\hline 2008 & $\begin{array}{r}39,300,000 \\
{[41,200,000]^{\mathrm{c}}}\end{array}$ & 93 & 11 & $31,600,000$ & $48,200,000$ & -- & -- & -- & -- & -- & -- \\
\hline \multicolumn{12}{|c|}{06821190 Platte River at Sharps Station, Missouri } \\
\hline 1980 & $1,530,000$ & -- & -- & -- & -- & 9 & 135,000 & -- & -- & -- & -- \\
\hline 1981 & $1,720,000$ & -- & -- & -- & -- & 10 & 177,000 & -- & -- & -- & -- \\
\hline 1982 & $27,400,000$ & -- & -- & -- & -- & 4 & $1,040,000$ & 62 & 151 & 67,900 & $4,870,000$ \\
\hline 1983 & $4,670,000$ & 79 & 102 & 631,000 & $17,100,000$ & 9 & 419,000 & 79 & 66 & 108,000 & $1,140,000$ \\
\hline 1984 & $10,800,000$ & 75 & 113 & $1,210,000$ & $42,200,000$ & 4 & 453,000 & 78 & 74 & 99,000 & $1,330,000$ \\
\hline 1985 & 989,000 & 75 & 89 & 166,000 & $3,300,000$ & 13 & 82,300 & 77 & 60 & 23,800 & 209,000 \\
\hline 1986 & $7,230,000$ & 81 & 101 & 976,000 & $26,400,000$ & 11 & 410,000 & 84 & 59 & 122,000 & $1,030,000$ \\
\hline 1987 & $2,620,000$ & 83 & 83 & 485,000 & $8,370,000$ & 20 & 205,000 & 88 & 51 & 70,600 & 470,000 \\
\hline 1988 & 296,000 & 82 & 61 & 83,300 & 765,000 & 20 & 26,600 & 88 & 36 & 12,600 & 49,700 \\
\hline 1989 & 619,000 & 91 & 65 & 162,000 & $1,660,000$ & 17 & 30,600 & 88 & 58 & 9,140 & 76,600 \\
\hline
\end{tabular}


Table 3. Annual suspended-sediment and suspended-sand loads, and annual LOADEST model characteristics, for selected sediment stations in the lower Missouri River Basin, 1976-2008-Continued

$\left[\mathrm{r}^{2}\right.$, regression model coefficient of determination; --, no data or not applicable; >, greater than; mm, millimeters]

\begin{tabular}{|c|c|c|c|c|c|c|c|c|c|c|c|}
\hline $\begin{array}{l}\text { Water } \\
\text { Year }\end{array}$ & Load (tons) & $\begin{array}{l}\text { LOADEST } \\
\text { model } r^{2}\end{array}$ & $\begin{array}{l}\text { LOADEST } \\
\text { model } \\
\text { coefficient } \\
\text { of } \\
\text { variation }^{\mathrm{a}} \\
\text { (percent) }^{\text {percention }}\end{array}$ & $\begin{array}{c}\text { Lower } \\
\text { 95-percent } \\
\text { confidence } \\
\text { interval of } \\
\text { LOADEST } \\
\text { load } \\
\text { estimate } \\
\text { (tons) }\end{array}$ & $\begin{array}{c}\text { Upper } \\
\text { 95-percent } \\
\text { confidence } \\
\text { interval of } \\
\text { LOADEST } \\
\text { load estimate } \\
\text { (tons) }\end{array}$ & $\begin{array}{l}\text { Percent of total } \\
\text { suspended- } \\
\text { sediment } \\
\text { load as sand } \\
(>0.0625 \mathrm{~mm})^{\mathrm{b}}\end{array}$ & $\begin{array}{c}\text { Annual } \\
\text { suspended } \\
\text { load (tons) }\end{array}$ & $\begin{array}{c}\text { LOADEST } \\
\text { model } r^{2}\end{array}$ & $\begin{array}{c}\text { LOADEST } \\
\text { model } \\
\text { coefficient } \\
\text { of variation } \\
\text { (percent) }\end{array}$ & $\begin{array}{c}\text { Lower } \\
\text { 95-percent } \\
\text { confidence } \\
\text { interval of } \\
\text { LOADEST } \\
\text { load } \\
\text { estimate } \\
\text { (tons) }\end{array}$ & $\begin{array}{c}\text { Upper } \\
\text { 95-percent } \\
\text { confidence } \\
\text { interval of } \\
\text { LOADEST load } \\
\text { estimate (tons) }\end{array}$ \\
\hline \multicolumn{12}{|c|}{06821190 Platte River at Sharps Station, Missouri-Continued } \\
\hline 1990 & $1,520,000$ & 90 & 46 & 583,000 & $3,260,000$ & 18 & 84,300 & 88 & 43 & 34,500 & 174,000 \\
\hline 1991 & 977,000 & 90 & 46 & 374,000 & $2,100,000$ & 18 & 55,800 & 88 & 43 & 23,100 & 114,000 \\
\hline 1992 & $2,200,000$ & 90 & 54 & 719,000 & $5,230,000$ & 17 & 110,000 & 88 & 48 & 40,300 & 244,000 \\
\hline \multicolumn{12}{|c|}{06892350 Kansas River at DeSoto, Kansas } \\
\hline 1976 & $4,330,000$ & 85 & 27 & $2,460,000$ & $7,070,000$ & 10 & 419,000 & 77 & 37 & 197,000 & 789,000 \\
\hline 1977 & $19,300,000$ & 85 & 26 & $11,300,000$ & $30,900,000$ & 8 & $1,640,000$ & 77 & 37 & 760,000 & $3,110,000$ \\
\hline 1978 & $6,440,000$ & 85 & 12 & $5,080,000$ & $8,060,000$ & 13 & 810,000 & 79 & 25 & 485,000 & $1,270,000$ \\
\hline 1979 & $13,200,000$ & 87 & 13 & $10,100,000$ & $16,900,000$ & 26 & $3,460,000$ & 78 & 32 & $1,800,000$ & $6,040,000$ \\
\hline 1980 & $6,700,000$ & 91 & 16 & $4,840,000$ & $9,070,000$ & 19 & $1,290,000$ & 92 & 43 & 532,000 & $2,640,000$ \\
\hline 1981 & $4,640,000$ & 92 & 17 & $3,280,000$ & $6,360,000$ & 7 & 306,000 & 92 & 47 & 115,000 & 663,000 \\
\hline 1982 & $21,900,000$ & 92 & 14 & $16,500,000$ & $28,400,000$ & -- & -- & -- & -- & -- & -- \\
\hline 1983 & $6,220,000$ & 90 & 18 & $4,330,000$ & $8,670,000$ & -- & -- & -- & -- & -- & -- \\
\hline 1984 & $17,200,000$ & 94 & 30 & $9,260,000$ & $29,400,000$ & -- & -- & -- & -- & -- & -- \\
\hline 1985 & $4,120,000$ & 93 & 24 & $2,490,000$ & $6,430,000$ & -- & -- & -- & -- & -- & -- \\
\hline 1986 & $11,800,000$ & 89 & 36 & $5,620,000$ & $22,100,000$ & -- & -- & -- & -- & -- & -- \\
\hline 1987 & $23,100,000$ & 93 & 29 & $12,700,000$ & $38,700,000$ & -- & -- & -- & -- & -- & -- \\
\hline 1988 & 577,000 & 94 & 16 & 414,000 & 782,000 & -- & -- & -- & -- & -- & -- \\
\hline 1989 & $4,360,000$ & 90 & 48 & $1,600,000$ & $9,620,000$ & -- & -- & -- & -- & -- & -- \\
\hline
\end{tabular}




\begin{tabular}{|c|c|c|c|c|c|c|c|c|c|c|c|}
\hline $\begin{array}{l}\text { Water } \\
\text { Year }\end{array}$ & Load (tons) & $\begin{array}{l}\text { LOADEST } \\
\text { model } r^{2}\end{array}$ & $\begin{array}{l}\text { LOADEST } \\
\text { model } \\
\text { coefficient } \\
\text { of } \\
\text { variation } \\
\text { (percent) }\end{array}$ & $\begin{array}{c}\text { Lower } \\
\text { 95-percent } \\
\text { confidence } \\
\text { interval of } \\
\text { LOADEST } \\
\text { load } \\
\text { estimate } \\
\text { (tons) }\end{array}$ & $\begin{array}{c}\text { Upper } \\
\text { 95-percent } \\
\text { confidence } \\
\text { interval of } \\
\text { LOADEST } \\
\text { load estimate } \\
\text { (tons) }\end{array}$ & $\begin{array}{l}\text { Percent of total } \\
\text { suspended- } \\
\text { sediment } \\
\text { load as sand } \\
(>0.0625 \mathrm{~mm})^{\mathrm{b}}\end{array}$ & $\begin{array}{c}\text { Annual } \\
\text { suspended } \\
\text { load (tons) }\end{array}$ & $\begin{array}{c}\text { LOADEST } \\
\text { model } r^{2}\end{array}$ & $\begin{array}{l}\text { LOADEST } \\
\text { model } \\
\text { coefficient } \\
\text { of variation } \\
\text { (percent) }\end{array}$ & $\begin{array}{c}\text { Lower } \\
\text { 95-percent } \\
\text { confidence } \\
\text { interval of } \\
\text { LOADEST } \\
\text { load } \\
\text { estimate } \\
\text { (tons) }\end{array}$ & $\begin{array}{c}\text { Upper } \\
\text { 95-percent } \\
\text { confidence } \\
\text { interval of } \\
\text { LOADEST load } \\
\text { estimate (tons) }\end{array}$ \\
\hline \multicolumn{12}{|c|}{06892350 Kansas River at DeSoto, Kansas_-Continued } \\
\hline 1990 & $8,000,000$ & 90 & 44 & $3,200,000$ & $16,700,000$ & -- & -- & -- & -- & -- & -- \\
\hline 1991 & $1,550,000$ & 90 & 35 & 749,000 & $2,850,000$ & -- & -- & -- & -- & -- & -- \\
\hline \multicolumn{12}{|c|}{06893000 Missouri River at Kansas City, Missouri } \\
\hline 1976 & $(53,400,000)^{\mathrm{e}}$ & -- & -- & -- & -- & 35 & $(18,700,000)^{\mathrm{e}}$ & -- & -- & -- & -- \\
\hline 1977 & $(25,100,000)^{\mathrm{e}}$ & -- & -- & -- & -- & 62 & $(15,600,000)^{\mathrm{e}}$ & -- & -- & -- & -- \\
\hline 1978 & $(51,600,000)^{\mathrm{e}}$ & -- & -- & -- & -- & 58 & $(29,900,000)^{\mathrm{e}}$ & -- & -- & -- & -- \\
\hline 1979 & $(54,200,000)^{\mathrm{e}}$ & -- & -- & -- & -- & 38 & $(20,800,000)^{\mathrm{e}}$ & -- & -- & -- & -- \\
\hline 1980 & $(45,800,000)^{\mathrm{e}}$ & -- & -- & -- & -- & 34 & $(15,600,000)^{\mathrm{e}}$ & -- & -- & -- & -- \\
\hline 1981 & $(30,000,000)^{\mathrm{e}}$ & -- & -- & -- & -- & 33 & $(9,880,000)^{\mathrm{e}}$ & -- & -- & -- & -- \\
\hline 1988 & $19,000,000$ & 92 & 26 & $11,000,000$ & $30,500,000$ & 56 & $10,700,000$ & 82 & 12 & $8,330,000$ & $13,400,000$ \\
\hline 1989 & $23,800,000$ & 92 & 20 & $15,900,000$ & $34,200,000$ & 32 & $7,650,000$ & 82 & 10 & $6,290,000$ & $9,210,000$ \\
\hline 1990 & $45,300,000$ & 93 & 16 & $32,500,000$ & $61,500,000$ & 20 & $9,250,000$ & 86 & 6 & $8,290,000$ & $10,300,000$ \\
\hline 1991 & $32,700,000$ & 91 & 16 & $23,700,000$ & $44,100,000$ & 22 & $7,320,000$ & 84 & 5 & $6,580,000$ & $8,120,000$ \\
\hline 1992 & $35,200,000$ & -- & -- & -- & -- & 27 & $9,520,000$ & -- & -- & -- & -- \\
\hline 1993 & $163,000,000$ & 81 & 32 & $83,800,000$ & $287,000,000$ & 17 & $27,900,000$ & 77 & 13 & $21,700,000$ & $35,400,000$ \\
\hline 1994 & $35,600,000$ & 83 & 10 & $29,100,000$ & $43,100,000$ & 33 & $11,900,000$ & 69 & 5 & $10,700,000$ & $13,200,000$ \\
\hline 1995 & $59,000,000$ & 88 & 16 & $42,600,000$ & $79,800,000$ & 24 & $14,200,000^{\mathrm{f}}$ & 44 & 7 & $11,500,000$ & $1,530,000$ \\
\hline 1996 & $40,200,000$ & 94 & 11 & $32,100,000$ & $49,800,000$ & 52 & $20,700,000$ & -- & -- & -- & -- \\
\hline 1997 & $94,000,000$ & 89 & 14 & $71,400,000$ & $122,000,000$ & 33 & $31,200,000$ & -- & -- & -- & -- \\
\hline 1998 & $68,500,000$ & 80 & 12 & $54,300,000$ & $85,200,000$ & 26 & $18,000,000$ & -- & -- & -- & -- \\
\hline
\end{tabular}


Table 3. Annual suspended-sediment and suspended-sand loads, and annual LOADEST model characteristics, for selected sediment stations in the lower Missouri River Basin, 1976-2008-Continued

$\left[\mathrm{r}^{2}\right.$, regression model coefficient of determination; --, no data or not applicable; >, greater than; mm, millimeters $]$

\begin{tabular}{|c|c|c|c|c|c|c|c|c|c|c|c|}
\hline $\begin{array}{l}\text { Water } \\
\text { Year }\end{array}$ & Load (tons) & $\begin{array}{l}\text { LOADEST } \\
\text { model } r^{2}\end{array}$ & $\begin{array}{l}\text { LOADEST } \\
\text { model } \\
\text { coefficient } \\
\text { of } \\
\text { variation } \\
\text { (percent) }\end{array}$ & $\begin{array}{l}\text { Lower } \\
\text { 95-percent } \\
\text { confidence } \\
\text { interval of } \\
\text { LOADEST } \\
\text { load } \\
\text { estimate } \\
\text { (tons) }\end{array}$ & $\begin{array}{c}\text { Upper } \\
\text { 95-percent } \\
\text { confidence } \\
\text { interval of } \\
\text { LOADEST } \\
\text { load estimate } \\
\text { (tons) }\end{array}$ & $\begin{array}{l}\text { Percent of total } \\
\text { suspended- } \\
\text { sediment } \\
\text { load as sand } \\
(>0.0625 \mathrm{~mm})^{\mathrm{b}}\end{array}$ & $\begin{array}{c}\text { Annual } \\
\text { suspended } \\
\text { load (tons) }\end{array}$ & $\begin{array}{l}\text { LOADEST } \\
\text { model } r^{2}\end{array}$ & $\begin{array}{l}\text { LOADEST } \\
\text { model } \\
\text { coefficient } \\
\text { of variation } \\
\text { (percent) }\end{array}$ & $\begin{array}{c}\text { Lower } \\
\text { 95-percent } \\
\text { confidence } \\
\text { interval of } \\
\text { LOADEST } \\
\text { load } \\
\text { estimate } \\
\text { (tons) }\end{array}$ & $\begin{array}{c}\text { Upper } \\
\text { 95-percent } \\
\text { confidence } \\
\text { interval of } \\
\text { LOADEST load } \\
\text { estimate (tons) }\end{array}$ \\
\hline \multicolumn{12}{|c|}{06893000 Missouri River at Kansas City, Missouri-Continued } \\
\hline 1999 & $114,000,000$ & 85 & 17 & $80,200,000$ & $157,000,000$ & 14 & $16,500,000$ & -- & -- & -- & -- \\
\hline 2000 & $16,800,000$ & 91 & 7 & $13,600,000$ & $20,500,000$ & 32 & $5,380,000$ & -- & -- & -- & -- \\
\hline 2001 & $43,200,000$ & 83 & 11 & $31,300,000$ & $58,200,000$ & 14 & $6,000,000$ & 51 & 11 & $4,820,000$ & $7,390,000$ \\
\hline 2002 & $15,600,000$ & -- & -- & -- & -- & 22 & $3,480,000$ & 58 & 10 & $2,860,000$ & $4,200,000$ \\
\hline 2003 & $17,300,000$ & 94 & 8 & $14,800,000$ & $20,200,000$ & 20 & $3,550,000$ & 75 & 7 & $3,100,000$ & $4,040,000$ \\
\hline 2004 & $30,700,000$ & 95 & 9 & $25,400,000$ & $36,700,000$ & 18 & $5,400,000$ & 82 & 14 & $4,040,000$ & $7,060,000$ \\
\hline 2005 & $30,200,000$ & -- & -- & -- & -- & 14 & $4,300,000$ & 82 & 14 & $3,240,000$ & $5,610,000$ \\
\hline 2006 & $15,000,000$ & 85 & 8 & $12,800,000$ & $17,600,000$ & -- & -- & -- & -- & -- & -- \\
\hline 2007 & $56,300,000$ & 88 & 22 & $36,200,000$ & $83,600,000$ & -- & -- & -- & -- & -- & -- \\
\hline 2008 & $59,200,000$ & -- & -- & -- & -- & -- & -- & -- & -- & -- & -- \\
\hline \multicolumn{12}{|c|}{06902000 Grand River at Sumner, Missouri } \\
\hline 1976 & $13,500,000$ & 89 & 82 & $2,560,000$ & $42,500,000$ & 15 & 983,000 & 73 & 84 & 181,000 & $3,140,000$ \\
\hline 1977 & $2,570,000$ & 93 & 49 & 926,000 & $5,750,000$ & 16 & 551,000 & 75 & 80 & 109,000 & $1,700,000$ \\
\hline 1978 & $22,200,000$ & 95 & 35 & $10,600,000$ & $41,200,000$ & 13 & $3,210,000$ & -- & -- & -- & -- \\
\hline 1979 & $17,600,000$ & 92 & 50 & $6,170,000$ & $39,900,000$ & 21 & $3,040,000$ & 73 & 84 & 551,000 & $9,770,000$ \\
\hline 1980 & $12,300,000$ & -- & -- & -- & -- & 13 & 401,000 & -- & -- & -- & -- \\
\hline 1981 & $22,200,000$ & 95 & 36 & $10,600,000$ & $41,200,000$ & 7 & $1,430,000$ & -- & -- & -- & -- \\
\hline 1982 & $26,900,000$ & 88 & 72 & $6,180,000$ & $77,300,000$ & 13 & $3,980,000$ & 61 & 93 & 622,000 & $13,700,000$ \\
\hline
\end{tabular}




\begin{tabular}{|c|c|c|c|c|c|c|c|c|c|c|c|}
\hline $\begin{array}{c}\text { Water } \\
\text { Year }\end{array}$ & Load (tons) & $\begin{array}{l}\text { LOADEST } \\
\text { model } r^{2}\end{array}$ & $\begin{array}{l}\text { LOADEST } \\
\text { model } \\
\text { coefficient } \\
\text { of } \\
\text { variation }^{\text {a }} \\
\text { (percent) }\end{array}$ & $\begin{array}{c}\text { Lower } \\
\text { 95-percent } \\
\text { confidence } \\
\text { interval of } \\
\text { LOADEST } \\
\text { load } \\
\text { estimate } \\
\text { (tons) }\end{array}$ & $\begin{array}{c}\text { Upper } \\
\text { 95-percent } \\
\text { confidence } \\
\text { interval of } \\
\text { LOADEST } \\
\text { load estimate } \\
\text { (tons) }\end{array}$ & $\begin{array}{l}\text { Percent of total } \\
\text { suspended- } \\
\text { sediment } \\
\text { load as sand } \\
(>0.0625 \mathrm{~mm})^{\mathrm{b}}\end{array}$ & $\begin{array}{c}\text { Annual } \\
\text { suspended } \\
\text { load (tons) }\end{array}$ & $\begin{array}{c}\text { LOADEST } \\
\text { model } r^{2}\end{array}$ & $\begin{array}{c}\text { LOADEST } \\
\text { model } \\
\text { coefficient } \\
\text { of variation } \\
\text { (percent) }\end{array}$ & $\begin{array}{c}\text { Lower } \\
\text { 95-percent } \\
\text { confidence } \\
\text { interval of } \\
\text { LOADEST } \\
\text { load } \\
\text { estimate } \\
\text { (tons) }\end{array}$ & $\begin{array}{c}\text { Upper } \\
\text { 95-percent } \\
\text { confidence } \\
\text { interval of } \\
\text { LOADEST Ioad } \\
\text { estimate (tons) }\end{array}$ \\
\hline \multicolumn{12}{|c|}{06902000 Grand River at Sumner, Missouri-Continued } \\
\hline 1983 & $5,180,000$ & 94 & 39 & $2,320,000$ & $10,100,000$ & 17 & $1,370,000$ & 76 & 53 & 452,000 & $3,210,000$ \\
\hline 1984 & $8,900,000$ & 89 & 52 & $3,060,000$ & $20,500,000$ & 10 & $1,380,000$ & 82 & 60 & 401,000 & $3,500,000$ \\
\hline 1985 & $2,190,000$ & 91 & 47 & 834,000 & $4,730,000$ & 24 & 515,000 & 83 & 88 & 88,000 & $1,700,000$ \\
\hline 1986 & $18,600,000$ & -- & -- & -- & -- & 9 & $1,120,000$ & 78 & 62 & 309,000 & $2,930,000$ \\
\hline 1987 & $11,900,000$ & 92 & 67 & $2,960,000$ & $32,700,000$ & 15 & $1,760,000$ & 88 & 79 & 350,000 & $5,400,000$ \\
\hline 1988 & $1,730,000$ & 93 & 53 & 578,000 & $4,050,000$ & 49 & 854,000 & 93 & 115 & 92,600 & $3,390,000$ \\
\hline 1989 & $1,080,000$ & 92 & 67 & 271,000 & $2,980,000$ & 23 & 254,000 & 83 & 146 & 17,800 & $1,160,000$ \\
\hline 1990 & $7,600,000$ & 92 & 55 & $2,450,000$ & $18,300,000$ & 18 & $1,360,000$ & 83 & 108 & 165,000 & $5,180,000$ \\
\hline 1991 & $13,700,000$ & 95 & 46 & $5,300,000$ & $29,400,000$ & 9 & $1,170,000$ & 84 & 101 & 158,000 & $4,270,000$ \\
\hline 1992 & $15,700,000$ & 95 & 45 & $6,200,000$ & $33,100,000$ & 5 & 738,000 & 84 & 90 & 121,000 & $2,490,000$ \\
\hline 1993 & $100,000,000$ & 95 & 54 & $32,400,000$ & $238,000,000$ & 2 & $2,360,000$ & 84 & 116 & 251,000 & $9,440,000$ \\
\hline \multicolumn{12}{|c|}{06905500 Chariton River at Prairie Hill, Missouri } \\
\hline 1979 & $1,750,000$ & 88 & 41 & 750,000 & $3,480,000$ & 18 & 200,000 & 87 & 76 & 42,400 & 597,000 \\
\hline 1980 & $2,590,000$ & 91 & 86 & 461,000 & $8,430,000$ & 25 & 591,000 & 87 & 102 & 78,600 & $2,170,000$ \\
\hline 1981 & $2,590,000$ & 90 & 76 & 554,000 & $7,710,000$ & 35 & $1,570,000$ & 87 & 61 & 444,000 & $4,040,000$ \\
\hline 1982 & $6,200,000$ & 90 & 38 & $2,800,000$ & $12,000,000$ & 40 & $2,500,000$ & 88 & 45 & 975,000 & $5,310,000$ \\
\hline 1983 & $4,280,000$ & 93 & 42 & $1,800,000$ & $8,650,000$ & 52 & $2,250,000$ & 89 & 65 & 592,000 & $6,040,000$ \\
\hline 1984 & $2,960,000$ & 93 & 43 & $1,210,000$ & $6,110,000$ & 40 & $1,220,000$ & 90 & 62 & 341,000 & $3,150,000$ \\
\hline 1985 & $2,990,000$ & 93 & 47 & $1,140,000$ & $6,450,000$ & 21 & 651,000 & 90 & 70 & 156,000 & $1,830,000$ \\
\hline 1986 & $6,040,000$ & 93 & 42 & $2,520,000$ & $12,300,000$ & 16 & 966,000 & 90 & 73 & 218,000 & $2,800,000$ \\
\hline
\end{tabular}


Table 3. Annual suspended-sediment and suspended-sand loads, and annual LOADEST model characteristics, for selected sediment stations in the lower Missouri River Basin, 1976-2008-Continued

$\left[\mathrm{r}^{2}\right.$, regression model coefficient of determination; --, no data or not applicable; >, greater than; mm, millimeters]

\begin{tabular}{|c|c|c|c|c|c|c|c|c|c|c|c|}
\hline $\begin{array}{l}\text { Water } \\
\text { Year }\end{array}$ & Load (tons) & $\begin{array}{l}\text { LOADEST } \\
\text { model } r^{2}\end{array}$ & $\begin{array}{l}\text { LOADEST } \\
\text { model } \\
\text { coefficient } \\
\text { of } \\
\text { variation }^{\mathrm{a}} \\
\text { (percent) }^{-}\end{array}$ & $\begin{array}{c}\text { Lower } \\
\text { 95-percent } \\
\text { confidence } \\
\text { interval of } \\
\text { LOADEST } \\
\text { load } \\
\text { estimate } \\
\text { (tons) }\end{array}$ & $\begin{array}{c}\text { Upper } \\
\text { 95-percent } \\
\text { confidence } \\
\text { interval of } \\
\text { LOADEST } \\
\text { load estimate } \\
\text { (tons) }\end{array}$ & $\begin{array}{l}\text { Percent of total } \\
\text { suspended- } \\
\text { sediment } \\
\text { load as sand } \\
(>0.0625 \mathrm{~mm})^{\mathrm{b}}\end{array}$ & $\begin{array}{c}\text { Annual } \\
\text { suspended } \\
\text { load (tons) }\end{array}$ & $\begin{array}{l}\text { LOADEST } \\
\text { model } r^{2}\end{array}$ & $\begin{array}{l}\text { LOADEST } \\
\text { model } \\
\text { coefficient } \\
\text { of variation } \\
\text { (percent) }\end{array}$ & $\begin{array}{c}\text { Lower } \\
\text { 95-percent } \\
\text { confidence } \\
\text { interval of } \\
\text { LOADEST } \\
\text { load } \\
\text { estimate } \\
\text { (tons) }\end{array}$ & $\begin{array}{c}\text { Upper } \\
\text { 95-percent } \\
\text { confidence } \\
\text { interval of } \\
\text { LOADEST load } \\
\text { estimate (tons) }\end{array}$ \\
\hline \multicolumn{12}{|c|}{06926510 Osage River at St. Thomas, Missouri } \\
\hline 1976 & 402,000 & 75 & 29 & 221,000 & 673,000 & 40 & 160,000 & 57 & 48 & 58,600 & 352,000 \\
\hline 1977 & 642,000 & 72 & 52 & 217,000 & $1,490,000$ & 41 & 266,000 & 55 & 75 & 57,900 & 786,000 \\
\hline 1978 & $1,140,000$ & 82 & 32 & 588,000 & $2,010,000$ & 49 & 566,000 & 68 & 44 & 228,000 & $1,180,000$ \\
\hline 1979 & 930,000 & -- & -- & -- & -- & 49 & 460,000 & 66 & 32 & 238,000 & 805,000 \\
\hline 1980 & $1,240,000$ & 71 & 57 & 377,000 & $3,050,000$ & 52 & 651,000 & 67 & 63 & 176,000 & $1,720,000$ \\
\hline 1981 & $1,180,000$ & 56 & 67 & 294,000 & $3,250,000$ & 63 & 758,000 & 66 & 71 & 154,000 & $1,900,000$ \\
\hline 1982 & $1,240,000$ & 72 & 64 & 331,000 & $3,280,000$ & 46 & 577,000 & 61 & 89 & 97,300 & $1,920,000$ \\
\hline 1983 & 669,000 & 89 & 25 & 397,000 & $1,060,000$ & 59 & 401,000 & 86 & 46 & 155,000 & 859,000 \\
\hline 1984 & 539,000 & 81 & 23 & 335,000 & 823,000 & 41 & 223,000 & 74 & 47 & 83,900 & 484,000 \\
\hline 1985 & 627,000 & 78 & 31 & 330,000 & $1,090,000$ & 27 & 170,000 & -- & -- & -- & -- \\
\hline 1986 & 347,000 & 66 & 36 & 163,000 & 653,000 & 32 & 114,000 & 72 & 30 & 62,000 & 194,000 \\
\hline 1987 & 550,000 & 72 & 44 & 220,000 & $1,150,000$ & 29 & 133,000 & -- & -- & -- & -- \\
\hline 1988 & 270,000 & 81 & 34 & 133,000 & 491,000 & 28 & 77,700 & 87 & 31 & 41,200 & 134,000 \\
\hline 1989 & 179,000 & 89 & 24 & 110,000 & 277,000 & 57 & 102,000 & -- & -- & -- & -- \\
\hline 1990 & $1,070,000$ & -- & -- & -- & -- & 26 & 283,000 & 71 & 79 & 57,200 & 866,000 \\
\hline
\end{tabular}




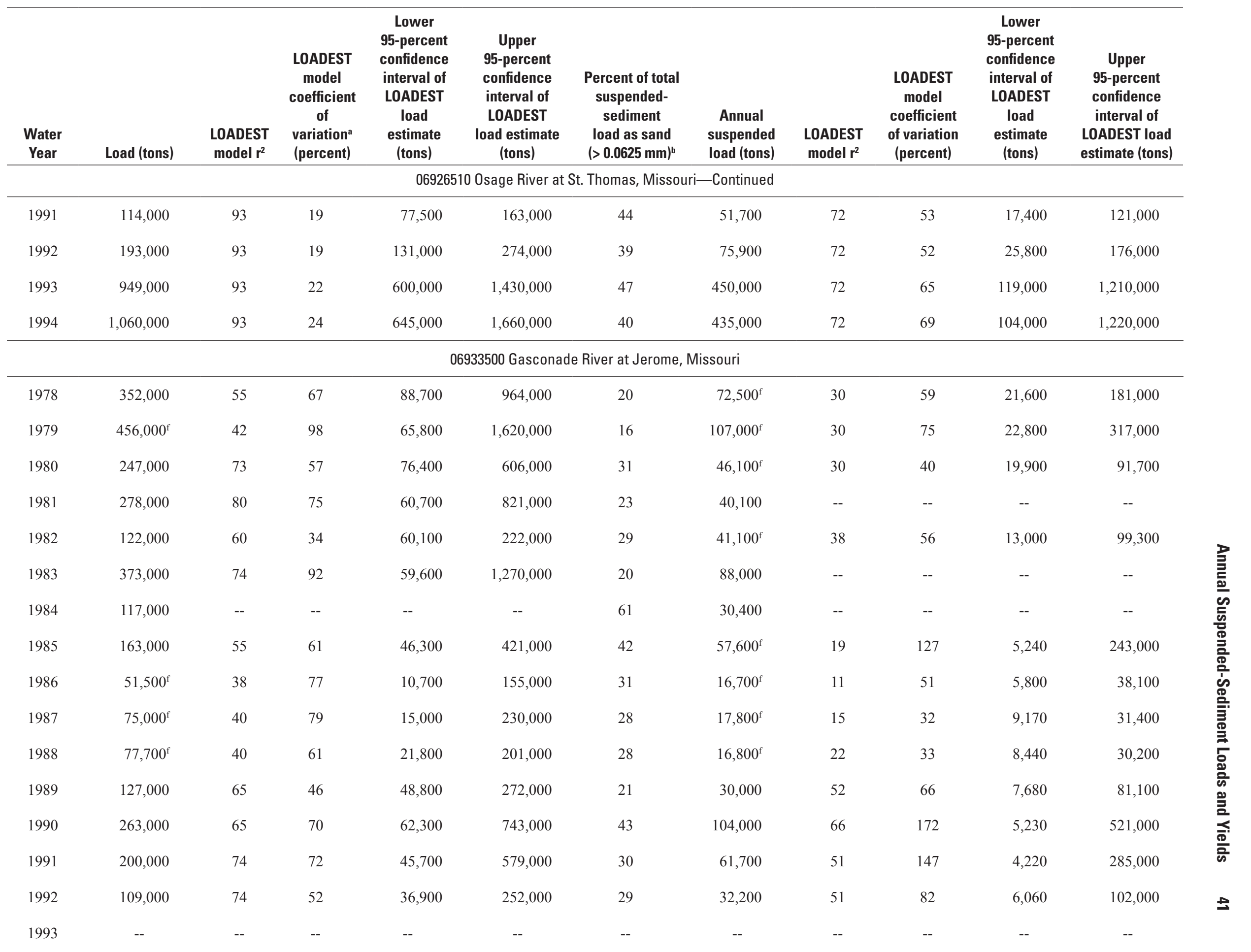


Table 3. Annual suspended-sediment and suspended-sand loads, and annual LOADEST model characteristics, for selected sediment stations in the lower Missouri River Basin,

$\left[\mathrm{r}^{2}\right.$, regression model coefficient of determination; --, no data or not applicable; >, greater than; mm, millimeters]

\begin{tabular}{|c|c|c|c|c|c|c|c|c|c|c|c|}
\hline $\begin{array}{l}\text { Water } \\
\text { Year }\end{array}$ & Load (tons) & $\begin{array}{l}\text { LOADEST } \\
\text { model } r^{2}\end{array}$ & $\begin{array}{l}\text { LOADEST } \\
\text { model } \\
\text { coefficient } \\
\text { of } \\
\text { variation }^{\mathrm{a}} \\
\text { (percent) }^{-}\end{array}$ & $\begin{array}{c}\text { Lower } \\
\text { 95-percent } \\
\text { confidence } \\
\text { interval of } \\
\text { LOADEST } \\
\text { load } \\
\text { estimate } \\
\text { (tons) }\end{array}$ & $\begin{array}{c}\text { Upper } \\
\text { 95-percent } \\
\text { confidence } \\
\text { interval of } \\
\text { LOADEST } \\
\text { load estimate } \\
\text { (tons) }\end{array}$ & $\begin{array}{l}\text { Percent of total } \\
\text { suspended- } \\
\text { sediment } \\
\text { load as sand } \\
(>0.0625 \mathrm{~mm})^{\mathrm{b}}\end{array}$ & $\begin{array}{c}\text { Annual } \\
\text { suspended } \\
\text { load (tons) }\end{array}$ & $\begin{array}{c}\text { LOADEST } \\
\text { model } r^{2}\end{array}$ & $\begin{array}{l}\text { LOADEST } \\
\text { model } \\
\text { coefficient } \\
\text { of variation } \\
\text { (percent) }\end{array}$ & $\begin{array}{c}\text { Lower } \\
\text { 95-percent } \\
\text { confidence } \\
\text { interval of } \\
\text { LOADEST } \\
\text { load } \\
\text { estimate } \\
\text { (tons) }\end{array}$ & $\begin{array}{c}\text { Upper } \\
\text { 95-percent } \\
\text { confidence } \\
\text { interval of } \\
\text { LOADEST Ioad } \\
\text { estimate (tons) }\end{array}$ \\
\hline \multicolumn{12}{|c|}{06934500 Missouri River at Hermann, Missouri } \\
\hline 1976 & $\begin{array}{l}36,000,000 \\
\quad(37,000,000)^{\mathrm{e}}\end{array}$ & -- & -- & -- & -- & 38 & $\begin{array}{l}14,700,000 \\
(14,000,000)^{\mathrm{e}}\end{array}$ & 80 & 7 & $13,200,000$ & $16,200,000$ \\
\hline 1977 & $\begin{array}{l}29,600,000 \\
\quad(26,600,000)^{\mathrm{e}}\end{array}$ & 85 & 8 & $25,400,000$ & $34,300,000$ & 38 & $\begin{array}{l}10,300,000 \\
(10,200,000)^{\mathrm{e}}\end{array}$ & -- & -- & -- & -- \\
\hline 1978 & $\begin{array}{l}89,300,000 \\
\quad(66,400,000)^{\mathrm{e}}\end{array}$ & -- & -- & -- & -- & 43 & $\begin{array}{l}32,900,000 \\
(28,700,000)^{\mathrm{e}}\end{array}$ & -- & -- & -- & -- \\
\hline 1979 & $\begin{array}{l}79,500,000 \\
\quad(71,100,000)^{\mathrm{e}}\end{array}$ & 83 & 7 & $68,500,000$ & $91,800,000$ & 32 & $\begin{array}{l}29,900,000 \\
(22,900,000)^{\mathrm{e}}\end{array}$ & -- & -- & -- & -- \\
\hline 1980 & $\begin{array}{l}40,900,000 \\
\quad(37,500,000)^{\mathrm{e}}\end{array}$ & -- & -- & -- & -- & 37 & $\begin{array}{l}15,000,000 \\
(13,700,000)^{\mathrm{e}}\end{array}$ & 76 & 7 & $13,000,000$ & $17,300,000$ \\
\hline 1981 & $\begin{array}{l}59,200,000 \\
\quad(62,100,000)^{\mathrm{e}}\end{array}$ & -- & -- & -- & -- & 23 & $\begin{array}{l}14,900,000 \\
(14,100,000)^{\mathrm{e}}\end{array}$ & -- & -- & -- & -- \\
\hline 1982 & $123,000,000$ & 90 & 11 & $98,700,000$ & $151,000,000$ & 24 & $29,700,000$ & 81 & 11 & $24,000,000$ & $36,300,000$ \\
\hline 1983 & $153,000,000$ & 91 & 11 & $123,000,000$ & $188,000,000$ & 22 & $33,300,000$ & -- & -- & -- & -- \\
\hline 1984 & $132,000,000$ & -- & -- & -- & -- & 25 & $33,200,000$ & -- & -- & -- & -- \\
\hline 1985 & $77,900,000$ & 74 & 13 & $59,600,000$ & $100,000,000$ & 28 & $21,700,000$ & -- & -- & -- & -- \\
\hline 1986 & $82,400,000$ & 66 & 14 & $62,100,000$ & $107,000,000$ & 27 & $22,400,000$ & -- & -- & -- & -- \\
\hline 1987 & $120,000,000$ & 76 & 16 & $86,100,000$ & $163,000,000$ & 25 & $30,200,000$ & -- & -- & -- & -- \\
\hline 1988 & $31,200,000$ & 86 & 9 & $26,100,000$ & $37,000,000$ & 45 & $13,900,000$ & -- & -- & -- & -- \\
\hline 1989 & $25,800,000$ & 92 & 14 & $19,400,000$ & $33,800,000$ & 30 & $7,800,000$ & 75 & 14 & $5,880,000$ & $10,200,000$ \\
\hline 1990 & $113,000,000$ & 92 & 16 & $82,800,000$ & $152,000,000$ & 17 & $19,300,000$ & 87 & 14 & $14,700,000$ & $24,900,000$ \\
\hline 1991 & $33,000,000$ & 93 & 11 & $26,500,000$ & $40,700,000$ & 24 & $8,030,000$ & -- & -- & -- & -- \\
\hline 1992 & $53,600,000$ & 94 & 12 & $42,100,000$ & $67,300,000$ & 17 & $9,040,000$ & 96 & 11 & $7,250,000$ & $11,100,000$ \\
\hline
\end{tabular}




\begin{tabular}{|c|c|c|c|c|c|c|c|c|c|c|c|}
\hline $\begin{array}{c}\text { Water } \\
\text { Year }\end{array}$ & Load (tons) & $\begin{array}{l}\text { LOADEST } \\
\text { model } \mathbf{r}^{2}\end{array}$ & $\begin{array}{l}\text { LOADEST } \\
\text { model } \\
\text { coefficient } \\
\text { of } \\
\text { variation }^{\mathrm{a}} \\
\text { (percent) }^{\text {perce }}\end{array}$ & $\begin{array}{c}\text { Lower } \\
\text { 95-percent } \\
\text { confidence } \\
\text { interval of } \\
\text { LOADEST } \\
\text { load } \\
\text { estimate } \\
\text { (tons) }\end{array}$ & $\begin{array}{c}\text { Upper } \\
\text { 95-percent } \\
\text { confidence } \\
\text { interval of } \\
\text { LOADEST } \\
\text { load estimate } \\
\text { (tons) }\end{array}$ & $\begin{array}{l}\text { Percent of total } \\
\text { suspended- } \\
\text { sediment } \\
\text { load as sand } \\
(>0.0625 \mathrm{~mm})^{\mathrm{b}}\end{array}$ & $\begin{array}{c}\text { Annual } \\
\text { suspended } \\
\text { load (tons) }\end{array}$ & $\begin{array}{c}\text { LOADEST } \\
\text { model } \mathbf{r}^{2}\end{array}$ & $\begin{array}{l}\text { LOADEST } \\
\text { model } \\
\text { coefficient } \\
\text { of variation } \\
\text { (percent) }\end{array}$ & $\begin{array}{c}\text { Lower } \\
\text { 95-percent } \\
\text { confidence } \\
\text { interval of } \\
\text { LOADEST } \\
\text { load } \\
\text { estimate } \\
\text { (tons) }\end{array}$ & $\begin{array}{c}\text { Upper } \\
\text { 95-percent } \\
\text { confidence } \\
\text { interval of } \\
\text { LOADEST load } \\
\text { estimate (tons) }\end{array}$ \\
\hline \multicolumn{12}{|c|}{06934500 Missouri River at Hermann, Missouri-Continued } \\
\hline 1993 & $177,000,000$ & 78 & 18 & $122,000,000$ & $247,000,000$ & 36 & $64,000,000$ & 95 & 10 & $52,800,000$ & $76,800,000$ \\
\hline 1994 & $58,300,000$ & 89 & 14 & $43,500,000$ & $76,400,000$ & 36 & $20,900,000$ & 96 & 10 & $16,900,000$ & $25,400,000$ \\
\hline 1995 & $103,000,000$ & 87 & 13 & $79,800,000$ & $132,000,000$ & 25 & $25,600,000$ & 87 & 12 & $20,000,000$ & $32,200,000$ \\
\hline 1996 & $63,500,000$ & 88 & 9 & $53,500,000$ & $74,700,000$ & 23 & $14,400,000$ & 89 & 7 & $12,500,000$ & $16,500,000$ \\
\hline 1997 & $96,000,000$ & 89 & 8 & $82,500,000$ & $111,000,000$ & 29 & $27,600,000$ & 89 & 8 & $23,600,000$ & $32,100,000$ \\
\hline 1998 & $75,200,000$ & 83 & 8 & $64,400,000$ & $87,300,000$ & 28 & $21,000,000$ & -- & -- & -- & -- \\
\hline 1999 & $110,600,000$ & 88 & 10 & $89,900,000$ & $135,000,000$ & 28 & $30,400,000$ & -- & -- & -- & -- \\
\hline 2000 & $14,100,000$ & 91 & 7 & $12,200,000$ & $16,200,000$ & 33 & $4,700,000$ & -- & -- & -- & -- \\
\hline 2001 & $69,200,000$ & 90 & 12 & $54,900,000$ & $86,000,000$ & 20 & $13,900,000$ & 87 & 11 & $11,100,000$ & $17,200,000$ \\
\hline 2002 & $44,700,000$ & 89 & 15 & $33,100,000$ & $59,000,000$ & 18 & $8,290,000$ & 84 & 13 & $6,380,000$ & $10,600,000$ \\
\hline 2003 & $11,500,000$ & 83 & 10 & $9,430,000$ & $13,900,000$ & 27 & $3,070,000$ & 75 & 12 & $2,390,000$ & $3,870,000$ \\
\hline 2004 & $40,500,000$ & 82 & 13 & $31,100,000$ & $51,900,000$ & 22 & $8,920,000$ & 76 & 20 & $5,980,000$ & $12,800,000$ \\
\hline 2005 & $51,900,000$ & 81 & 17 & $37,000,000$ & $70,900,000$ & 27 & $13,900,000$ & 71 & 36 & $6,600,000$ & $26,000,000$ \\
\hline 2006 & $\begin{array}{l}8,880,000 \\
\quad[8,600,000]^{c}\end{array}$ & 85 & 13 & $68,500,000$ & $113,000,000$ & 31 & $2,770,000$ & -- & -- & -- & -- \\
\hline 2007 & $\begin{array}{l}36,200,000 \\
\quad[44,500,000]^{\mathrm{c}}\end{array}$ & 87 & 11 & $28,900,000$ & $44,700,000$ & 28 & $10,200,000$ & 86 & 11 & $8,100,000$ & $12,600,000$ \\
\hline 2008 & $\begin{array}{l}88,600,000 \\
{[71,300,000]^{\mathrm{c}}}\end{array}$ & 70 & 20 & $59,000,000$ & $128,000,000$ & 23 & $20,400,000$ & -- & -- & -- & -- \\
\hline
\end{tabular}

${ }^{a}$ Coefficient of Variation determined by the ratio of the model daily standard error of the prediction and the mean daily model flux.

${ }^{\mathrm{b}}$ Determined as the ratio of total sand load to total annual load.

' Suspended-sediment load values in brackets determined from regression models of instantaneous-turbidity data and suspended sediment concentration.

${ }^{\mathrm{d}}$ Sum of daily computed sediment loads obtained from U.S. Geological Survey (2009).

${ }^{e}$ Value in parentheses obtained from daily computed sediment loads determined by the U.S. Army Corps of Engineers (U.S. Army Corps of Engineers, unpub. data, 1975-1981).

${ }^{\mathrm{f}}$ LOADEST model explains less than 50 percent of variation in predicted suspended-sediment concentrations used in load determination. 
Table 4. Annual suspended-sediment and suspended-sand yields for selected sediment stations in the lower Missouri River Basin, 1976-2008.

[tons $/ \mathrm{mi}^{2}$, tons per square mile; --, no data or not applicable]

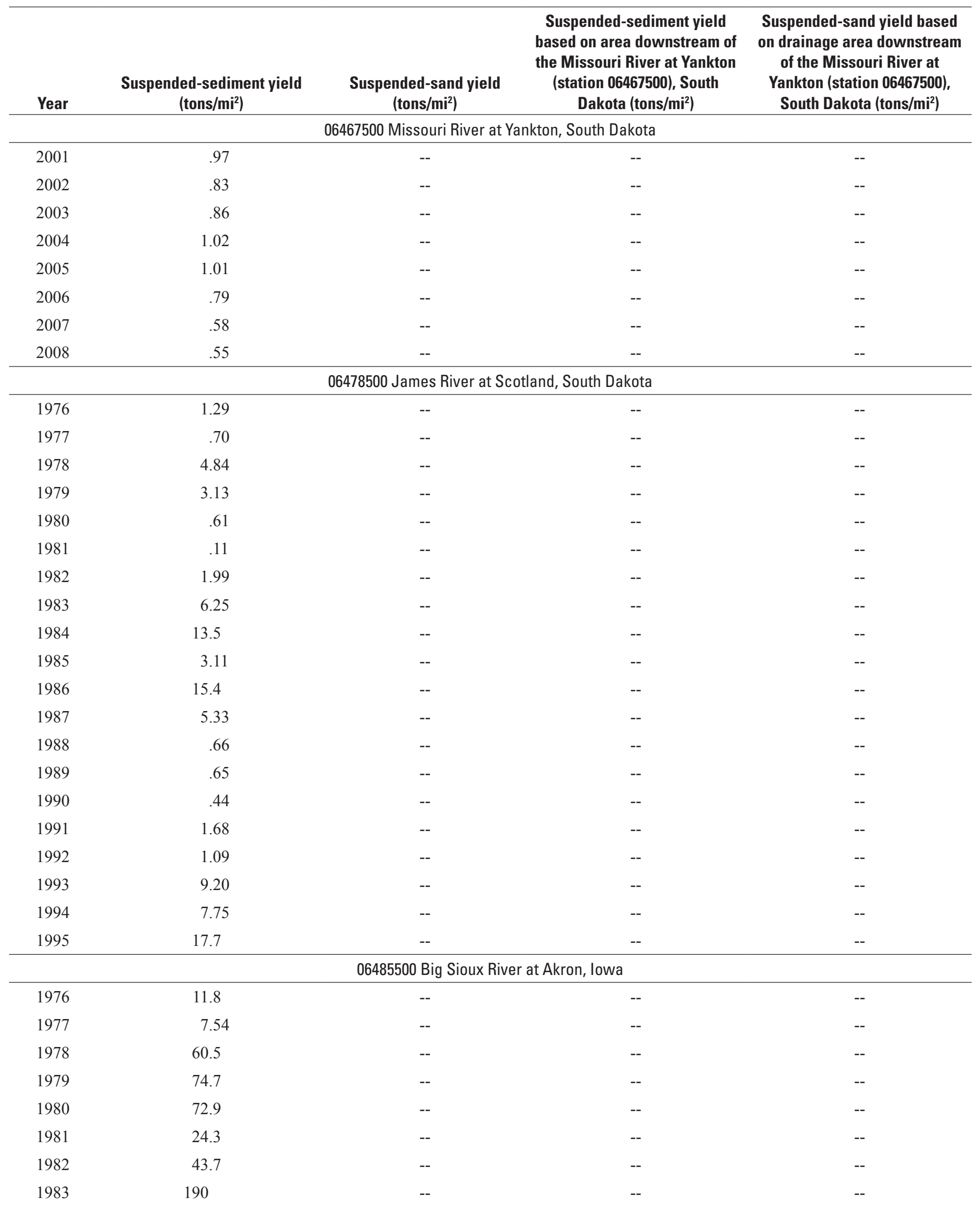


Table 4. Annual suspended-sediment and suspended-sand yields for selected sediment stations in the lower Missouri River Basin, 1976-2008-Continued

[tons $/ \mathrm{mi}^{2}$, tons per square mile; --, no data or not applicable]

\begin{tabular}{|c|c|c|c|c|}
\hline Year & $\begin{array}{c}\text { Suspended-sediment yield } \\
\text { (tons } / \mathrm{mi}^{2} \text { ) }\end{array}$ & $\begin{array}{c}\text { Suspended-sand yield } \\
\text { (tons } / \mathrm{mi}^{2} \text { ) }\end{array}$ & $\begin{array}{l}\text { Suspended-sediment yield } \\
\text { based on area downstream of } \\
\text { the Missouri River at Yankton } \\
\text { (station 06467500), South } \\
\text { Dakota (tons/mi²) }\end{array}$ & $\begin{array}{c}\text { Suspended-sand yield based } \\
\text { on drainage area downstream } \\
\text { of the Missouri River at } \\
\text { Yankton (station 06467500), } \\
\text { South Dakota (tons/mi²) }\end{array}$ \\
\hline \multicolumn{5}{|c|}{06485500 Big Sioux River at Akron, lowa-Continued } \\
\hline 1984 & 370 & -- & -- & -- \\
\hline 1986 & 286 & -- & -- & -- \\
\hline 1987 & 81.7 & -- & -- & -- \\
\hline 1988 & 28.5 & -- & -- & -- \\
\hline 1989 & 17.6 & -- & -- & -- \\
\hline 1993 & 556 & -- & -- & -- \\
\hline 1994 & 169 & -- & -- & -- \\
\hline \multicolumn{5}{|c|}{06486000 Missouri River at Sioux City, lowa } \\
\hline 1976 & 61.7 & -- & 553 & -- \\
\hline 1977 & 36.6 & -- & 328 & -- \\
\hline 1978 & 43.9 & -- & 393 & -- \\
\hline 1979 & 61.4 & -- & 550 & -- \\
\hline 1980 & 33.7 & -- & 302 & -- \\
\hline 1987 & 31.4 & 24.4 & 282 & 219 \\
\hline 1988 & 26 & 17.6 & 233 & 158 \\
\hline 1989 & 19.7 & 12.2 & 177 & 109 \\
\hline 1990 & 11.5 & 7.1 & 103 & 63.2 \\
\hline 1991 & 12.5 & 6.7 & 112 & 60.4 \\
\hline 1992 & 14.9 & -- & 133 & -- \\
\hline 1993 & 27.6 & -- & 248 & -- \\
\hline 1994 & 20.5 & -- & 184 & -- \\
\hline 1995 & 30.8 & -- & 276 & -- \\
\hline 1996 & 47.7 & -- & 428 & -- \\
\hline 1997 & 66 & -- & 592 & -- \\
\hline 1998 & 38.5 & -- & 345 & -- \\
\hline 1999 & 30.3 & -- & 271 & -- \\
\hline 2000 & 22.2 & -- & 199 & -- \\
\hline 2004 & 13.8 & -- & 124 & -- \\
\hline
\end{tabular}


Table 4. Annual suspended-sediment and suspended-sand yields for selected sediment stations in the lower Missouri River Basin, 1976-2008-Continued

[tons $/ \mathrm{mi}^{2}$, tons per square mile; --, no data or not applicable]

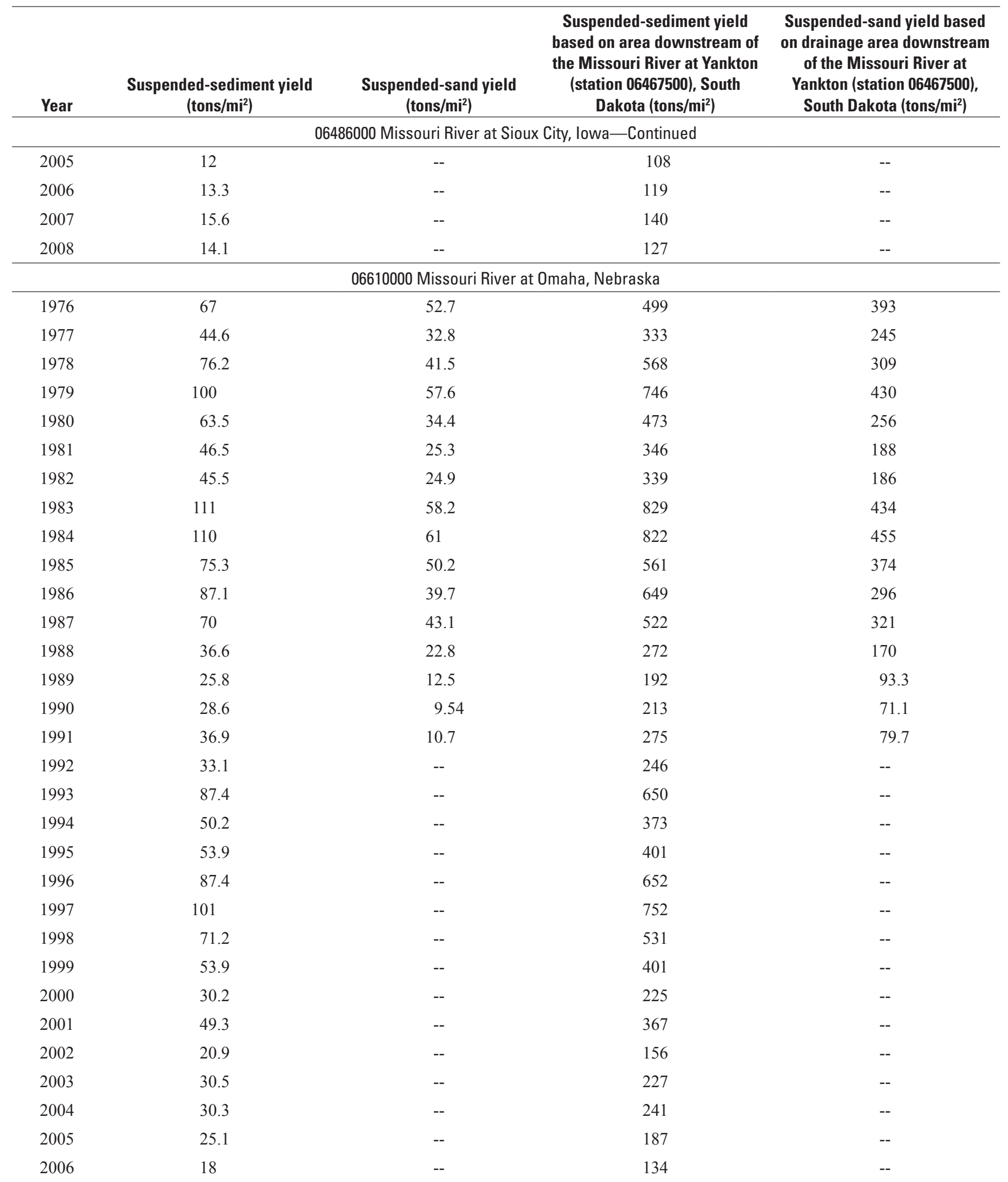


Table 4. Annual suspended-sediment and suspended-sand yields for selected sediment stations in the lower Missouri River Basin, 1976-2008-Continued

[tons $/ \mathrm{mi}^{2}$, tons per square mile; --, no data or not applicable]

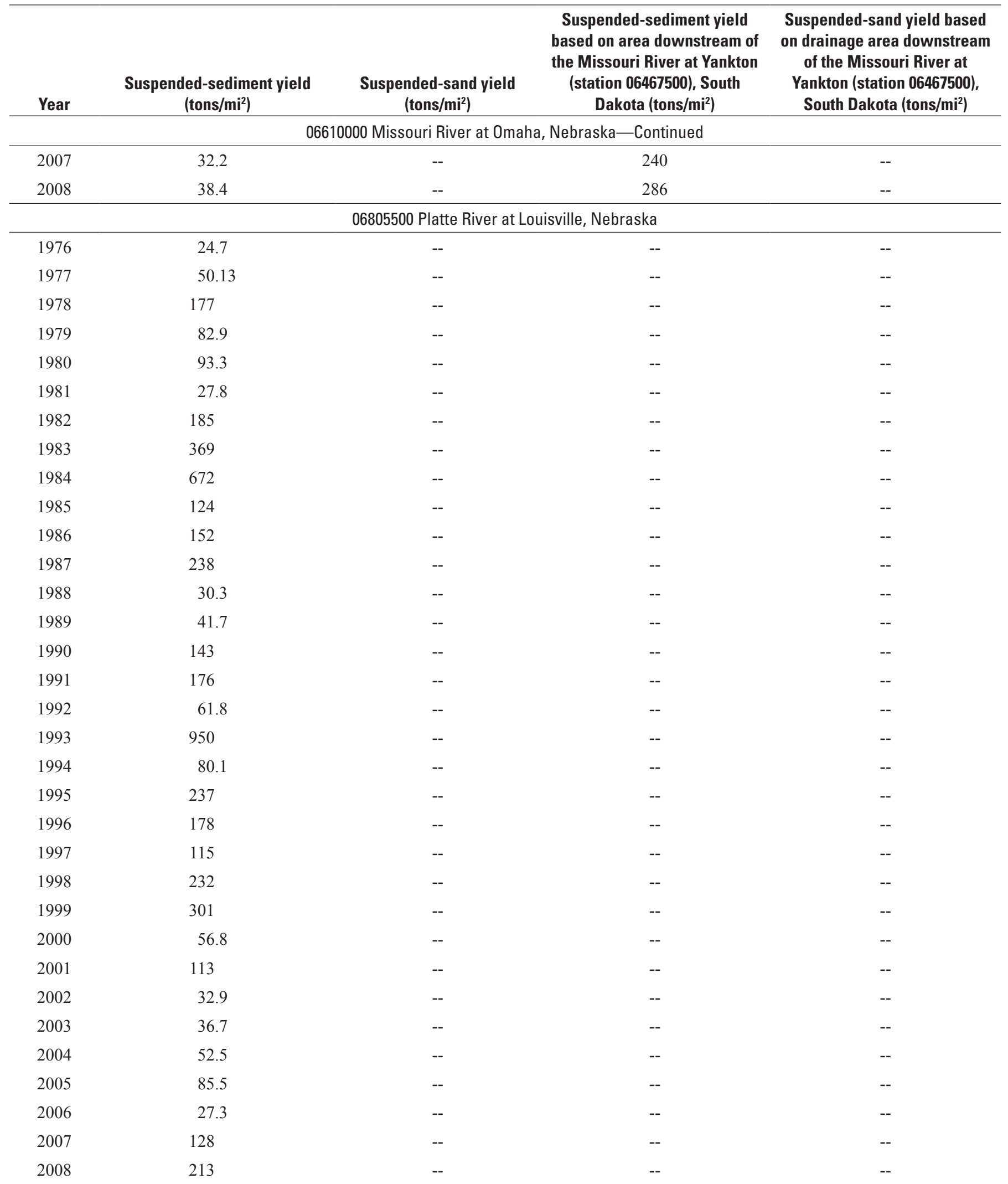


Table 4. Annual suspended-sediment and suspended-sand yields for selected sediment stations in the lower Missouri River Basin, 1976-2008-Continued

[tons $/ \mathrm{mi}^{2}$, tons per square mile; --, no data or not applicable]

\begin{tabular}{|c|c|c|c|c|}
\hline Year & $\begin{array}{c}\text { Suspended-sediment yield } \\
\left.\text { (tons } / \mathrm{mi}^{2}\right)\end{array}$ & $\begin{array}{c}\text { Suspended-sand yield } \\
\left.\text { (tons } / \mathrm{mi}^{2}\right)\end{array}$ & $\begin{array}{l}\text { Suspended-sediment yield } \\
\text { based on area downstream of } \\
\text { the Missouri River at Yankton } \\
\text { (station 06467500), South } \\
\text { Dakota (tons/mi) }\end{array}$ & $\begin{array}{c}\text { Suspended-sand yield based } \\
\text { on drainage area downstream } \\
\text { of the Missouri River at } \\
\text { Yankton (station } 06467500 \text { ), } \\
\text { South Dakota (tons/mi²) }\end{array}$ \\
\hline \multicolumn{5}{|c|}{06807000 Missouri River at Nebraska City, Nebraska } \\
\hline 1976 & 62.3 & -- & 233 & -- \\
\hline 1978 & 81 & 51.2 & 254 & 161 \\
\hline 1979 & 95.6 & 62.7 & 300 & 197 \\
\hline 1980 & 47.8 & 37.1 & 150 & 116 \\
\hline 1981 & 40 & 20.4 & 126 & 64.2 \\
\hline 1985 & 106 & 51.2 & 334 & 161 \\
\hline 1986 & 93.6 & 45.9 & 294 & 144 \\
\hline 1987 & 123 & 51.7 & 385 & 162 \\
\hline 1988 & 37.1 & 23 & 116 & 72.3 \\
\hline 1989 & 29.8 & 16.2 & 93.5 & 50.8 \\
\hline 1990 & 39.8 & 13.9 & 125 & 43.8 \\
\hline 1991 & 46.8 & 17 & 147 & 53.3 \\
\hline 1992 & 46.1 & -- & 145 & -- \\
\hline 1999 & 76.8 & -- & 242 & -- \\
\hline 2000 & 34.6 & -- & 109 & -- \\
\hline 2001 & 56.1 & -- & 176 & -- \\
\hline 2002 & 27.3 & -- & 86 & -- \\
\hline 2003 & 35.8 & -- & 113 & -- \\
\hline 2004 & 39.8 & -- & 125 & -- \\
\hline 2005 & 34.9 & -- & 110 & -- \\
\hline 2006 & 22.8 & -- & 71.5 & -- \\
\hline 2007 & 53.9 & -- & 169 & -- \\
\hline 2008 & 82.4 & -- & 259 & -- \\
\hline
\end{tabular}

06810000 Nishnabotna River at Hamburg, lowa

$\begin{array}{lr}1982 & 2,210 \\ 1983 & 1,590 \\ 1984 & 5,220 \\ 1985 & 196 \\ 1986 & 1,760\end{array}$


Table 4. Annual suspended-sediment and suspended-sand yields for selected sediment stations in the lower Missouri River Basin, 1976-2008-Continued

[tons $/ \mathrm{mi}^{2}$, tons per square mile; --, no data or not applicable]

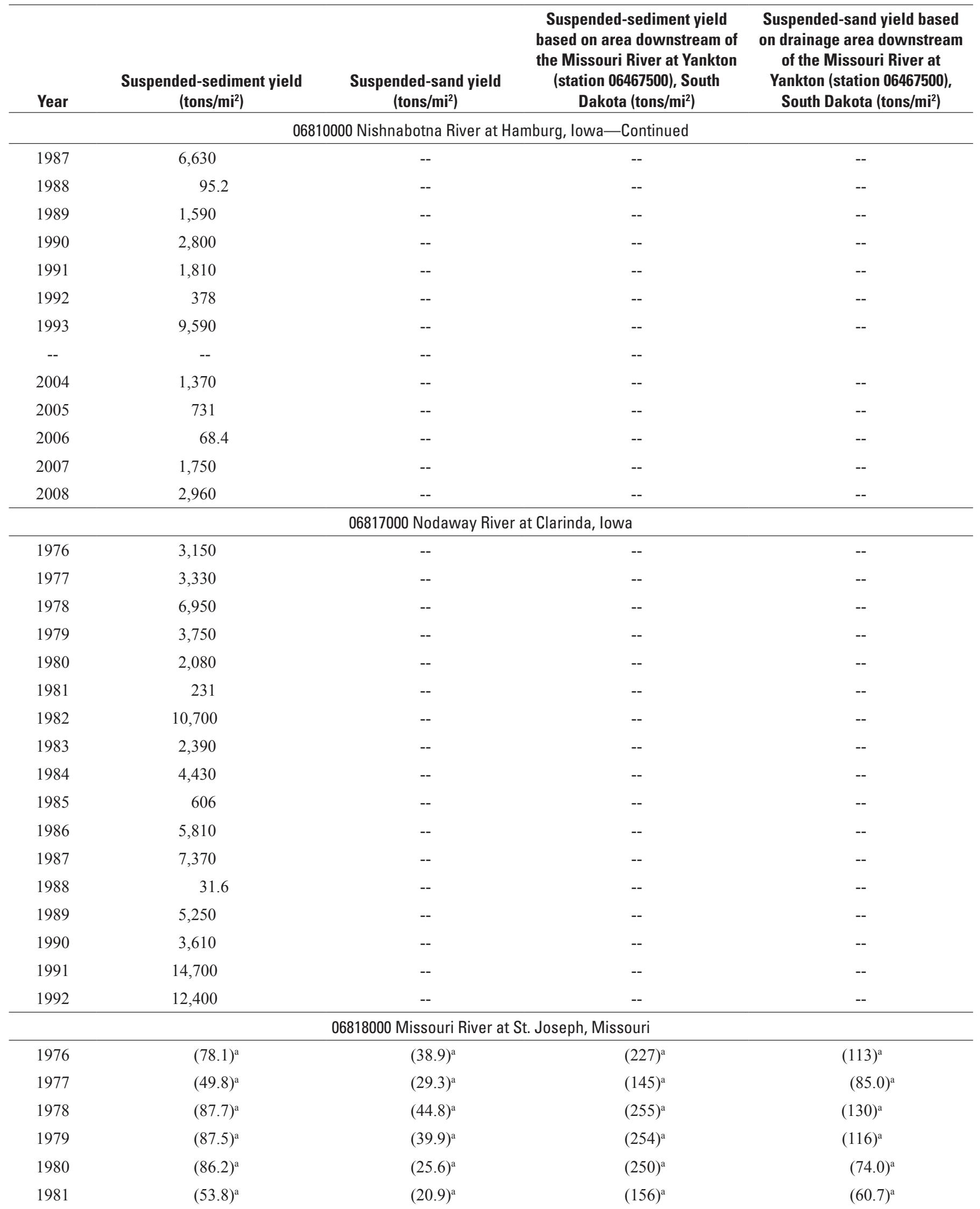


Table 4. Annual suspended-sediment and suspended-sand yields for selected sediment stations in the lower Missouri River Basin, 1976-2008-Continued

[tons $/ \mathrm{mi}^{2}$, tons per square mile; --, no data or not applicable]

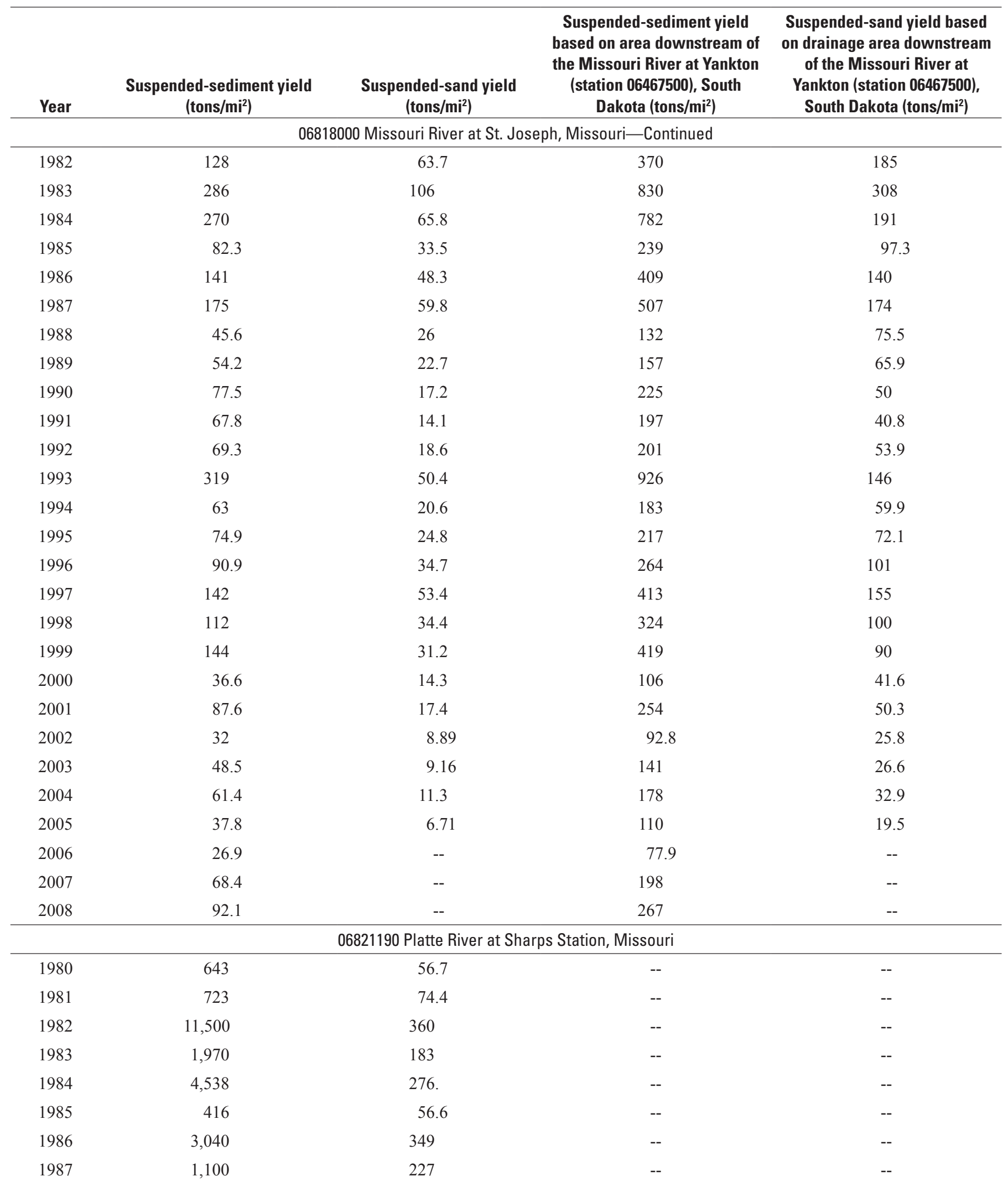


Table 4. Annual suspended-sediment and suspended-sand yields for selected sediment stations in the lower Missouri River Basin, 1976-2008-Continued

[tons $/ \mathrm{mi}^{2}$, tons per square mile; --, no data or not applicable]

\begin{tabular}{|c|c|c|c|c|}
\hline Year & $\begin{array}{c}\text { Suspended-sediment yield } \\
\left.\text { (tons } / \mathrm{mi}^{2}\right)\end{array}$ & $\begin{array}{c}\text { Suspended-sand yield } \\
\left.\text { (tons } / \mathrm{mi}^{2}\right)\end{array}$ & $\begin{array}{l}\text { Suspended-sediment yield } \\
\text { based on area downstream of } \\
\text { the Missouri River at Yankton } \\
\text { (station 06467500), South } \\
\text { Dakota (tons/mi) }\end{array}$ & $\begin{array}{c}\text { Suspended-sand yield based } \\
\text { on drainage area downstream } \\
\text { of the Missouri River at } \\
\text { Yankton (station 06467500), } \\
\text { South Dakota (tons/mi²) }\end{array}$ \\
\hline \multicolumn{5}{|c|}{06821190 Platte River at Sharps Station, Missouri-Continued } \\
\hline 1988 & 124 & 25.9 & -- & -- \\
\hline 1990 & 638 & 117 & -- & -- \\
\hline 1991 & 411 & 76.2 & -- & -- \\
\hline 1992 & 925 & 159 & -- & -- \\
\hline \multicolumn{5}{|c|}{06892350 Kansas River at DeSoto, Kansas } \\
\hline 1979 & 221 & 57.9 & -- & -- \\
\hline 1980 & 112 & 21.6 & -- & -- \\
\hline 1981 & 77.6 & 5.11 & -- & -- \\
\hline 1982 & 366 & -- & -- & -- \\
\hline 1983 & 104 & -- & -- & -- \\
\hline 1984 & 288 & -- & -- & -- \\
\hline 1985 & 69 & -- & -- & -- \\
\hline 1986 & 198 & -- & -- & -- \\
\hline 1987 & 386 & -- & -- & -- \\
\hline 1976 & $(110)^{\mathrm{a}}$ & $(38.6)^{\mathrm{a}}$ & $(261)^{\mathrm{a}}$ & $(91.3)^{\mathrm{a}}$ \\
\hline 1977 & $(51.8)^{\mathrm{a}}$ & $(32.2)^{\mathrm{a}}$ & $(122)^{\mathrm{a}}$ & $(76.1)^{\mathrm{a}}$ \\
\hline 1978 & $(107)^{\mathrm{a}}$ & $(61.8)^{\mathrm{a}}$ & $(252)^{\mathrm{a}}$ & $(146)^{\mathrm{a}}$ \\
\hline 1979 & $(112)^{\mathrm{a}}$ & $(43.0)^{\mathrm{a}}$ & $(265)^{\mathrm{a}}$ & $(102)^{\mathrm{a}}$ \\
\hline 1980 & $(94.7)^{\mathrm{a}}$ & $(32.2)^{\mathrm{a}}$ & $(224)^{\mathrm{a}}$ & $(76.1)^{\mathrm{a}}$ \\
\hline 1981 & $(62.0)^{\mathrm{a}}$ & $(20.4)^{\mathrm{a}}$ & $(147)^{\mathrm{a}}$ & $(48.3)^{\mathrm{a}}$ \\
\hline -- & -- & -- & -- & -- \\
\hline 1988 & 39.2 & 27.7 & 92.9 & 65.5 \\
\hline 1989 & 49.2 & 17.3 & 116 & 40.8 \\
\hline 1990 & 93.6 & 19.1 & 221 & 45.2 \\
\hline 1991 & 67.5 & 15.1 & 160 & 35.8 \\
\hline 1992 & 72.7 & 19.7 & 172 & 46.5 \\
\hline 1993 & 337 & 57.7 & 797 & 136 \\
\hline
\end{tabular}


Table 4. Annual suspended-sediment and suspended-sand yields for selected sediment stations in the lower Missouri River Basin, 1976-2008-Continued

[tons $/ \mathrm{mi}^{2}$, tons per square mile; --, no data or not applicable]

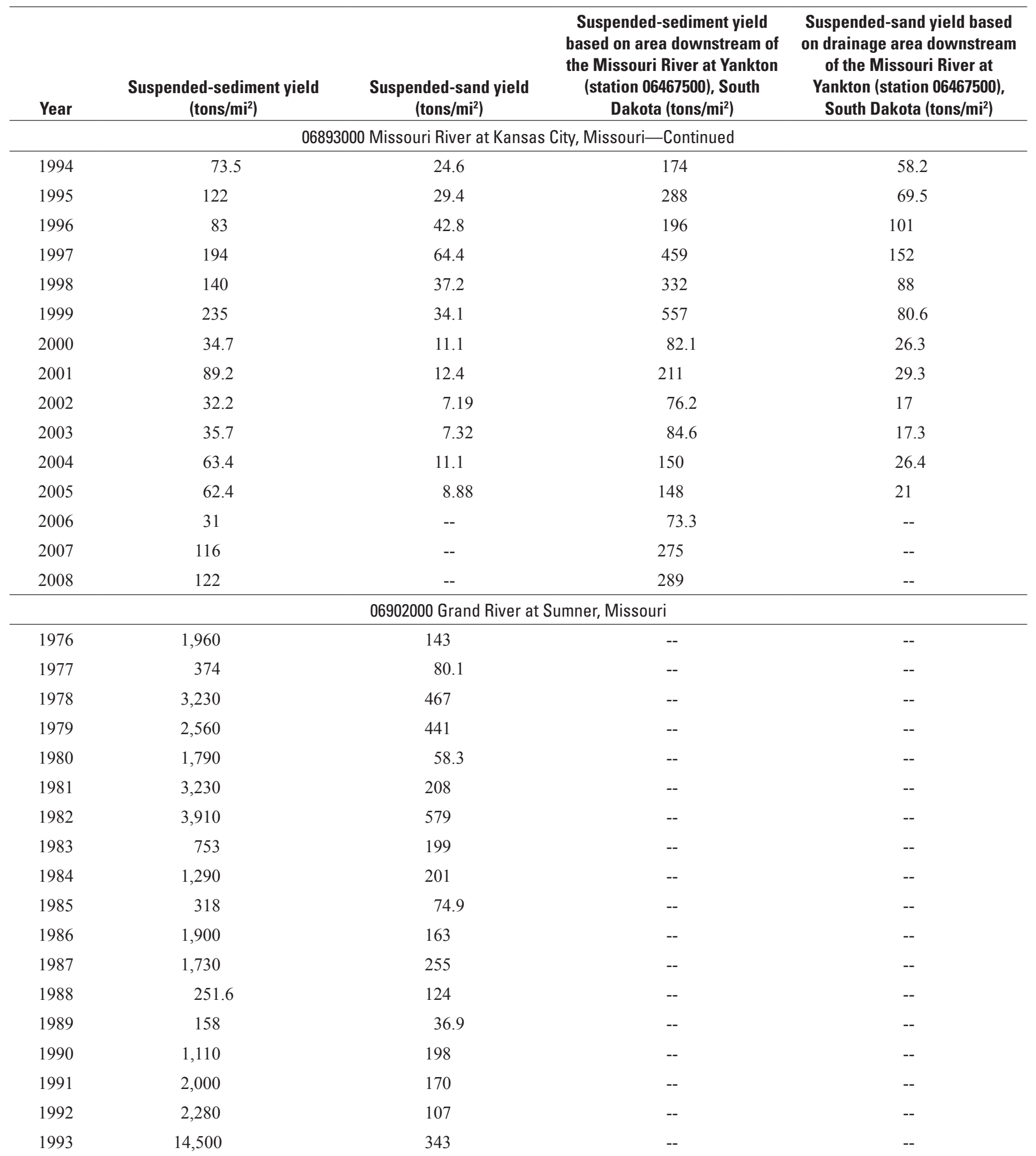


Table 4. Annual suspended-sediment and suspended-sand yields for selected sediment stations in the lower Missouri River Basin, 1976-2008-Continued

[tons $/ \mathrm{mi}^{2}$, tons per square mile; --, no data or not applicable]

\begin{tabular}{|c|c|c|c|c|}
\hline Year & $\begin{array}{c}\text { Suspended-sediment yield } \\
\left(\text { tons } / \mathrm{mi}^{2}\right)\end{array}$ & $\begin{array}{c}\text { Suspended-sand yield } \\
\text { (tons } / \mathrm{mi}^{2} \text { ) }\end{array}$ & $\begin{array}{l}\text { Suspended-sediment yield } \\
\text { based on area downstream of } \\
\text { the Missouri River at Yankton } \\
\text { (station 06467500), South } \\
\text { Dakota (tons/mi) }\end{array}$ & $\begin{array}{c}\text { Suspended-sand yield based } \\
\text { on drainage area downstream } \\
\text { of the Missouri River at } \\
\text { Yankton (station 06467500), } \\
\text { South Dakota (tons } / \mathrm{mi}^{2} \text { ) }\end{array}$ \\
\hline \multicolumn{5}{|c|}{06905500 Chariton River at Prairie Hill, Missouri } \\
\hline 1979 & 1,385 & 316 & -- & -- \\
\hline 1981 & 3,240 & 1,150 & -- & -- \\
\hline 1982 & 3,320 & 1,340 & -- & -- \\
\hline 1983 & 2,290 & 1,210 & -- & -- \\
\hline 1984 & 1,580 & 651 & -- & -- \\
\hline 1976 & 27.6 & 11 & -- & -- \\
\hline 1977 & 44 & 18.2 & -- & -- \\
\hline 1978 & 78.2 & 38.8 & -- & -- \\
\hline 1979 & 63.8 & 31.5 & -- & -- \\
\hline 1980 & 85 & 44.6 & -- & -- \\
\hline 1981 & 80.9 & 52 & -- & -- \\
\hline 1982 & 85 & 39.6 & -- & -- \\
\hline 1983 & 45.9 & 27.5 & -- & -- \\
\hline 1984 & 37 & 15.3 & -- & -- \\
\hline 1990 & 73.4 & 19.4 & -- & -- \\
\hline 1991 & 7.85 & 3.55 & -- & -- \\
\hline 1992 & 13.2 & 5.21 & -- & -- \\
\hline 1993 & 65.1 & 30.9 & -- & -- \\
\hline 1994 & 73 & 29.8 & -- & -- \\
\hline \multicolumn{5}{|c|}{06933500 Gasconade River at Jerome, Missouri } \\
\hline 1978 & 124 & 25.5 & -- & -- \\
\hline 1979 & 161 & 37.6 & -- & -- \\
\hline 1980 & 87 & 16.2 & -- & -- \\
\hline 1981 & 97.9 & 14.1 & -- & -- \\
\hline 1982 & 43 & 14.5 & -- & -- \\
\hline 1983 & 131 & 31 & -- & -- \\
\hline 1984 & 41.2 & 10.7 & -- & -- \\
\hline 1985 & 57.4 & 20.3 & -- & -- \\
\hline
\end{tabular}


Table 4. Annual suspended-sediment and suspended-sand yields for selected sediment stations in the lower Missouri River Basin, 1976-2008-Continued

[tons $/ \mathrm{mi}^{2}$, tons per square mile; --, no data or not applicable]

\begin{tabular}{|c|c|c|c|c|}
\hline Year & $\begin{array}{c}\text { Suspended-sediment yield } \\
\left.\text { (tons } / \mathrm{mi}^{2}\right)\end{array}$ & $\begin{array}{c}\text { Suspended-sand yield } \\
\left.\text { (tons } / \mathrm{mi}^{2}\right)\end{array}$ & $\begin{array}{c}\text { Suspended-sediment yield } \\
\text { based on area downstream of } \\
\text { the Missouri River at Yankton } \\
\text { (station 06467500), South } \\
\text { Dakota (tons/mi) }\end{array}$ & $\begin{array}{l}\text { Suspended-sand yield based } \\
\text { on drainage area downstream } \\
\text { of the Missouri River at } \\
\text { Yankton (station } 06467500 \text { ), } \\
\text { South Dakota (tons/mi²) }\end{array}$ \\
\hline \multicolumn{5}{|c|}{06933500 Gasconade River at Jerome, Missouri-Continued } \\
\hline 1986 & 18.1 & 5.9 & -- & -- \\
\hline 1988 & 27.1 & 5.9 & -- & -- \\
\hline 1989 & 44.7 & 10.5 & -- & -- \\
\hline 1990 & 93 & 36.6 & -- & -- \\
\hline 1991 & 70.4 & 21.7 & -- & -- \\
\hline \multicolumn{5}{|c|}{06934500 Missouri River at Hermann, Missouri } \\
\hline 1976 & $68.9(70.8)^{\mathrm{a}}$ & $28.1(26.8)^{\mathrm{a}}$ & $148(152)^{\mathrm{a}}$ & $60.5(57.4)^{\mathrm{a}}$ \\
\hline 1977 & $56.7(50.9)^{\mathrm{a}}$ & $19.7(19.5)^{\mathrm{a}}$ & $121(109)^{\mathrm{a}}$ & $42.4(42.1)^{\mathrm{a}}$ \\
\hline 1978 & $171(127)^{\mathrm{a}}$ & $63.0(54.9)^{\mathrm{a}}$ & $367(273)^{\mathrm{a}}$ & $135(118)^{\mathrm{a}}$ \\
\hline 1979 & $152(136)^{\mathrm{a}}$ & $57.2(43.8)^{\mathrm{a}}$ & $327(293)^{\mathrm{a}}$ & $123(94.4)^{\mathrm{a}}$ \\
\hline 1980 & $78.3(71.8)^{\mathrm{a}}$ & $28.7(26.2)^{\mathrm{a}}$ & $168(154)^{\mathrm{a}}$ & $61.7(56.6)^{\mathrm{a}}$ \\
\hline 1981 & $113(119)^{\mathrm{a}}$ & $28.5(27.0)^{\mathrm{a}}$ & $244(255)^{\mathrm{a}}$ & $61.3(58.0)^{\mathrm{a}}$ \\
\hline 1982 & 235 & 56.8 & 506 & 122 \\
\hline 1983 & 293 & 63.7 & 629 & 137 \\
\hline 1990 & 216 & 36.9 & 465 & 79.4 \\
\hline 1991 & 63.2 & 15.4 & 136 & 33 \\
\hline 1992 & 103 & 17.3 & 221 & 37.2 \\
\hline 1993 & 339 & 122 & 728 & 263 \\
\hline 1994 & 112 & 40 & 240 & 86 \\
\hline 1995 & 197 & 49 & 424 & 105 \\
\hline 1996 & 122 & 27.6 & 261 & 59.2 \\
\hline 1997 & 184 & 52.8 & 395 & 114 \\
\hline 1998 & 144 & 40.2 & 309 & 86.4 \\
\hline 1999 & 212 & 58.2 & 455 & 125 \\
\hline 2000 & 27 & 9 & 58 & 19.3 \\
\hline 2001 & 132 & 26.6 & 285 & 57.2 \\
\hline 2002 & 86 & 15.9 & 184 & 34.1 \\
\hline
\end{tabular}


Table 4. Annual suspended-sediment and suspended-sand yields for selected sediment stations in the lower Missouri River Basin, 1976-2008-Continued

[tons $/ \mathrm{mi}^{2}$, tons per square mile; --, no data or not applicable]

\begin{tabular}{|c|c|c|c|c|}
\hline Year & $\begin{array}{l}\text { Suspended-sediment yield } \\
\left.\text { (tons } / \mathrm{mi}^{2}\right)\end{array}$ & $\begin{array}{c}\text { Suspended-sand yield } \\
\text { (tons } / \mathrm{mi}^{2} \text { ) }\end{array}$ & $\begin{array}{l}\text { Suspended-sediment yield } \\
\text { based on area downstream of } \\
\text { the Missouri River at Yankton } \\
\text { (station 06467500), South } \\
\text { Dakota (tons/mi²) }\end{array}$ & $\begin{array}{l}\text { Suspended-sand yield based } \\
\text { on drainage area downstream } \\
\text { of the Missouri River at } \\
\text { Yankton (station 06467500), } \\
\text { South Dakota (tons/mi²) }\end{array}$ \\
\hline \multicolumn{5}{|c|}{06934500 Missouri River at Hermann, Missouri-Continued } \\
\hline 2003 & 22 & 5.88 & 47.3 & 12.6 \\
\hline 2005 & 99.3 & 26.6 & 214 & 57.2 \\
\hline 2006 & 17 & 5.3 & 36.5 & 11.4 \\
\hline 2007 & 69.3 & 19.5 & 149 & 42 \\
\hline 2008 & 170 & 39 & 364 & 84 \\
\hline
\end{tabular}

${ }^{a}$ Values in parentheses were calculated from suspended sediment load estimates obtained from U.S. Army Corps of Engineers (unpub. data, 1975-81). 


\section{Summary}

The U.S. Geological Survey collects and analyzes suspended-sediment data in the Missouri River Basin as part of the Sediment Data Program with the U.S. Army Corps of Engineers, as part of the U.S. Geological Survey National Stream Quality Accounting Network, and in association with other U.S. Geological Survey cooperative-study programs with State and local agencies. To address the need for additional sediment information on the lower Missouri River, the U.S. Geological Survey, in cooperation with the U.S. Army Corps of Engineers, conducted a study to determine suspended-sediment characteristics and suspended-sediment loads at selected streamgaging stations. This report describes sediment data, load estimation techniques, and suspendedsediment loads and yields for 18 stations within the lower Missouri River Basin that have sediment and streamflow record for water years 1976 through 2008.

Suspended-sediment and suspended sand loads were computed for those stations and years within the 1976-2008 period for which loads had not been previously determined and sufficient data were available. The data used for determination of annual suspended-sediment and suspendedsand loads were retrieved from the U.S. Geological Survey NWIS database and data archives. Data included suspendedsediment concentrations, sediment particle size, turbidity, and streamflow for variable periods of record at the 18 U.S. Geological Survey streamgaging stations.

Annual suspended-sediment and suspended-sand loads provided in this report were determined using three techniques. These included the subdivision method, regression of instantaneous turbidity with suspended-sediment concentrations at selected stations, or by means of regression techniques using the Load Estimator (LOADEST) software. Characteristics of the suspended-sediment and streamflow data collected at the 18 monitoring stations and the tabulated annual suspended-sediment and suspended-sand loads and yields are presented.

\section{References Cited}

Blevins, D.W., 2006, The Response of Suspended Sediment, Turbidity, and Velocity to Historical Alterations of the Missouri River: U.S. Geological Survey Circular 1301, 8p.

Cohn, T.A., 1988, Adjusted maximum likelihood estimation of the moments of lognormal populations from type I censored samples: U.S. Geological Survey Open-File Report 88-350, 34 p.
Cohn, T.A., Gilroy, E.J., and Baier, W.G., 1992, Estimating fluvial transport of trace constituents using a regression model with data subject to censoring: Proceedings of the Joint Statistical Meeting, Boston, August 9-13, 1992, p. $142-151$.

Edwards, T.K., and Glysson, D.G., 1999, Field methods for measurement of fluvial sediment: U.S. Geological Survey Techniques of Water-Resources Investigations, book 3 , chap. C2, 89 p.

Hooper, R.P., Goolsby, D.A., Rickert, D.A., and McKenzie, W.W., 1997, NASQAN—A program to monitor the water quality of the Nation's large rivers: U.S. Geological Survey Fact Sheet 055-97, 6 p.

Horowitz, A.J., 2003, An evaluation of sediment rating curves for estimating suspended sediment concentrations for subsequent flux calculations: Hydrological Processes, v. 17 , p. 3,387-3,409.

Jacobson, R.B., and D.L. Galat, 2006, Flow and form in rehabilitation of large-river ecosystems: An example from the Lower Missouri River: Geomorphology, v. 77, p. 249-269.

Jacobson, R.B., Blevins, D.W., and Bitner, C.J., 2009, Sediment regime constraints on river restoration-An example from the lower Missouri River: Geological Society of America Special Papers 451, 22p.

Judge, G.G., Hill, R.C., Griffiths, W.E., Lutkepohl, H., and Lee, T.C., 1988, Introduction to the theory and practice of econometrics ( $2 \mathrm{~d}$ ed.): New York, John Wiley and Sons, $1,024 \mathrm{p}$.

Keown, M.P., Dardeau, E.A., and Causey, E.M., 1981, Characterization of the suspended-sediment regime and bed-material gradation of the Mississippi River Basin: U.S. Army Corps of Engineers Waterways Experiment Station Potamology Program Report 1, v. 1, 494 p.

Koltun, G.F., Gray, J.R., and McElhone, T.J., 1994, User's Manual for SEDCALC, a computer program for computation of suspended-sediment discharge: U.S. Geological Survey Open-File Report 94-459, 46 p.

Koltun, G.F., Eberle, M., Gray, J.R., Glysson, G.D, 2006, User's manual for the Graphical Constituent Loading Analysis System (GCLAS), U.S. Geological Survey Techniques and Methods, 4-C1, $51 \mathrm{p}$.

Meade, R. H., 1995, Contaminants in the Mississippi River, 1987-92: U.S. Geological Survey Circular 1133, 140 p.

Porterfield, G., 1972, Computation of fluvial-sediment discharge: U.S. Geological Survey Techniques of WaterResources Investigations, book 3, chap. C3, 66 p. 
Rasmussen, P.P., Gray, J.R., Glysson, G.D., and Ziegler, A.C., 2009, Guidelines and procedures for computing time-series suspended sediment concentrations and loads from in-stream turbidity-sensor and streamflow data: U.S. Geological Survey Techniques and Methods Book 3, Chapter C4, 54 p.

Runkel, R.L., Crawford, C.G., and Cohn, T.A., 2004, Load Estimator (LOADEST) - A FORTRAN program for estimating constituent loads in streams and rivers: U.S. Geological Survey Techniques and Methods book 4, chap. A5, $69 \mathrm{p}$.

Szalona, J.J., 1982, Development of a bag-type suspendedsediment sampler: Minneapolis, Minn., St. Anthony Falls Hydraulics Laboratory, Federal Inter-Agency Sedimentation Project, Report Y, 32 p.

Turnbull, B.W., and Weiss, L., 1978, A likelihood ratio statistic for testing goodness of fit with randomly censored data: Biometrics, v. 34, p. 367-375.

U.S. Army Corps of Engineers, 1951, Suspended Sediment in the Missouri River-Daily Record

for Water Years 1937-1948: Omaha, Nebraska, U.S. Army Corps of Engineers, Missouri River Division, 219 p.

U.S. Army Corps of Engineers, 1957, Suspended Sediment in the Missouri River-Daily Record for Water Years 19491954: Omaha, Nebraska, U.S. Army Corps of Engineers, Missouri River Division, 210 p.

U.S. Army Corps of Engineers, 1965, Suspended Sediment in the Missouri River-Daily Record for Water Years 19551959: Omaha, Nebraska, U.S. Army Corps of Engineers, Missouri River Division, 118 p.

U.S. Army Corps of Engineers, 1970, Suspended Sediment in the Missouri River-Daily Record for Water Years 19601964: Omaha, Nebraska, U.S. Army Corps of Engineers, Missouri River Division, 190 p.

U.S. Army Corps of Engineers, 1972, Suspended Sediment in the Missouri River - Daily Record for Water Years 19651969: Omaha, Nebraska, U.S. Army Corps of Engineers, Missouri River Division, 248 p.

U.S. Army Corps of Engineers, 1976, Suspended Sediment in the Missouri River-Daily Record for Water Years 1970-1974: Kansas City, Missouri, U.S. Army Corps of Engineers, Missouri River Division, 201 p.

U.S. Army Corps of Engineers, 1980, Potamology Investigation Missouri River, Rulo, Nebraska to Mouth: Kansas City, Missouri, U.S. Army Corps of Engineers, Missouri River Division Sediment Series, No. 22, 105 p.
U.S. Fish and Wildlife Service, 2003, Amendment to the 2000 Biological Opinion on the Operation of the Missouri River Main Stem Reservoir System, Operation and Maintenance of the Missouri River Bank Stabilization and Navigation Project, and Operation of the Kansas River Reservoir System: U.S. Fish and Wildlife Service, 308 p., accessed May 27, 2010 , at http://www.nwd-mr.usace.army.mil/ mmanual/FinalBO2003.pdf.

U.S. Geological Survey, 2009, USGS water data for the Nation: U.S. Geological Survey National Water Information System Web interface, accessed December 23, 2009, at http://waterdata.usgs.gov/nwis/.

Walling, D.E., 1977, Assessing the accuracy of suspended sediment rating curves for a small basin: Water Resources Research, v. 13, p. 531-538.

Wagner, R.J., Boulger, R.W., Jr., Oblinger, C.J., and Smith, B.A., 2006, Guidelines and standard procedures for continuous water-quality monitors - station operation, record computation, and data reporting: U.S. Geological Survey Techniques and Methods 1-D3, 51 p., 8 attachments, available on Web, accessed May 27, 2010, at http://pubs.water.usgs.gov/tm1d3.

Ward, J.R., and Harr, C.A., eds., 1990, Methods for collection and processing of surface-water and bed-material samples for physical and chemical analyses: U.S. Geological Survey Open-File Report 90-140, 71 p. 


\section{Appendix 1.}

The Excel spreadsheet Appendix-1.xls contains daily mean streamflow and suspendedsediment and suspended-sand concentration data used in LOADEST determinations of annual loads for selected Missouri River mainstem and tributary stations, 1976-2008. 
Publishing support provided by

Rolla and Lafayette Publishing Service Centers 


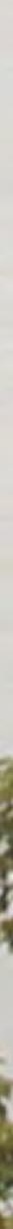

